\title{
THE EIGHTEENTH-CENTURY NOVEL IN \\ THEORY AND PRACTICE
}




\section{THE EIGHTEENTH-CENTURY NOVEL IN THEORY AND PRACTICE}

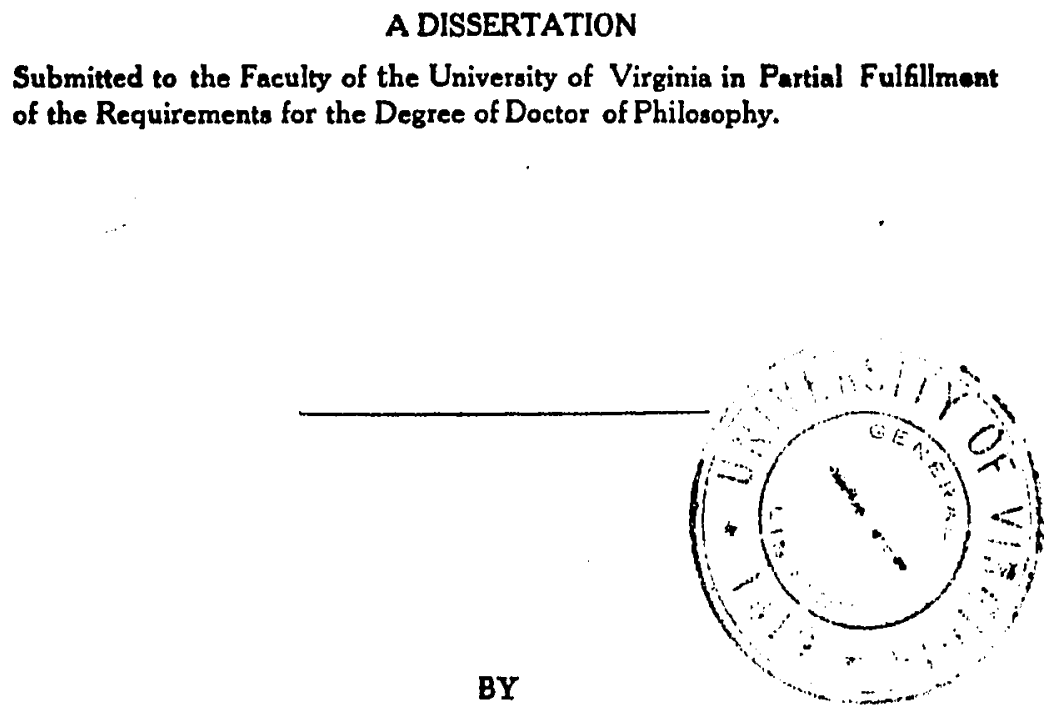

CHARLES HERBERT HUFFMAN, $M$. A.

Published Bs 
19

66384 


\section{PREFACE}

The research for this dissertation was begun and continued under the direction of Professor John Calvin Metcalf, of the Linden Kent Memorial School of English Literature in the University of Virginia. A graduate course in the Eighteenth-Century Novel, conducted by Professor Metcalf, included an investigation and appraisal of authors' methods, aims, and purposes. General search for this information led to the inference that the only authoritative source of it was the writings of the authors themselves; more extended search led to the conclusion that there was a great deal of interesting material on the subject, but that it was scattered and disconnected. It was thought desirable to have a collection of these writings, arranged in a unified and more accessible form. So far as the writer knows, none has been made. The present work is the result of an effort to perform this task.

The investigation begins with the novel of character, and includes within its compass the literary productions by leading authors only, from Richardson to Godwin. The inordinate length of many eighteenth-century novels made it apparent from the outset that a detailed study of every English novel in this period would be impossible within the scope of this dissertation. But such, fortunately, was not necessary; for the really great novelists blazed the trail and pointed the way. Writers of less importance added no new theory, nor did they vary the practice except wherein imitation and inferior literary talents led to corruption. Very few references have been made to their works; for in what they said and did, they but reflected the judgments of their superiors. Their opinions would not materially strengthen this work.

The method selected for this dissertation is to study in detail and to quote at some length from the prefaces, introductory chapters, letters, and novels by leading English novelists of the eighteenth century. Selections have been made from each author, and prominence is given to those 
passages which disclose artistic aims and purposes more or less common to all. No attempt has been made, therefore, to include every phase of this subject. The writer has thought it well to show that in some fundamental matters there was a unity of methods and motives greater than has been generally recognized. There has been, too, but little effort at interpretation; the quotations need none. "When what is done is either strange or striking," said Roderick Random, "we prefer to be told by the very man who did it." Prose fiction was both strange and striking to Roderick and his contemporaries in the eighteenth century. The masters of the new art shall speak for themselves.

I wish to acknowledge my indebtedness to Mr. John S. Patton, Librarian of the University of Virginia, for helpful suggestions regarding sources of investigation; to Miss Mary Louise Dinwiddie, Assistant Librarian, for patient and accurate direction in securing the sources; to my wife for untiring assistance in preparing the manuscript; to Professor James Southall Wilson, Poe Professor of English, University of Virginia, who read the book in manuscript, for scholarly criticism of its style. But my deepest obligation is to Professor John Calvin Metcalf, Linden Kent Memorial Professor of English Literature, University of Virginia, for stern, but kindly and sympathetic criticism at every step. His keen interest, his sound scholarship, and his ripe experience have afforded invaluable assistance in many ways.

University, Virginia,

C. H. H.

April, 1920. 


\section{CONTENTS}

\section{CHAPTER I}

Types Contributory to the Novel . . . . . . . . . ${ }_{7}^{\text {Page }}$

CHAPTER II

Rise of the Modern Novel: Crystallization of Theory . . 24 CHAPTER III

The Avowed Purposes of the Novel . . . . . . . . 43 CHAPTER IV

Means of Reaching the Inner Life . . . . . . . . $\quad 66$

CHAPTER V

The "Gothic" Novel and Romanticism . . . . . . 86

CHAPTER VI

The Democratic Idea . . . . . . . . . . . . 114

CHAPTER VII

Conclusions . . . . . . . . . . . . . . . 132

Bibliography . . . . . . . . . . . . . . 135

Index . . . . . . . . . . . . . . 137 


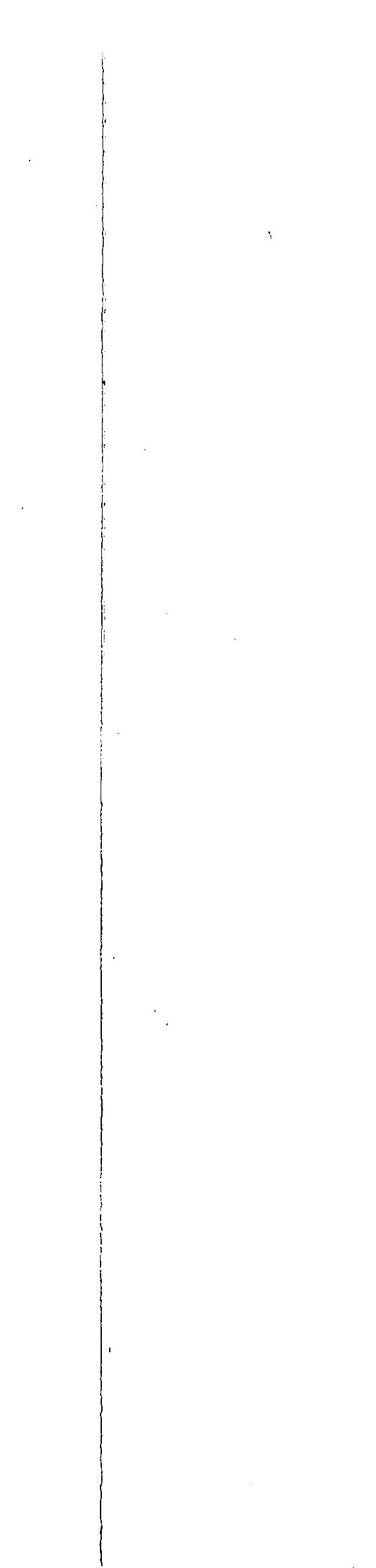




\section{CHAPTER I}

\section{TYPES CONTRIBUTORY TO THE NOVEL}

The eighteenth century was a period of beginnings. In the field of literature there were many things new, some of which proved to be permanent. There are many nineteenth-century verse forms that can be traced to the eighteenth, if, indeed, an exact counterpart cannot be found for the first time in the works of that period. But prose especially, in the course of its development, assumed its modern aspect then at the hands of Dryden, Addison, Defoe, Swift, Johnson, and Goldsmith. Dryden gave directness to prose; Addison, simplicity, joined with refinement and elegance. Defoe, downright plainness; Swift, precision and clearness; Johnson, formality, regularity, elevation and poise; Goldsmith, delicacy, ease, grace, and charm. The masters left these fundamental qualities of prose style as a legacy to their times-a legacy that the printer of Salisbury Court grasped very soon as a medium for narrative expression. The rise of the novel as a distinct type of literature, therefore, appears to have been almost contemporaneous with the general use of prose in established literary forms. Professor Saintsbury calls attention to uncertainty of opinion in reference to the exact beginning of the English novel; but he thinks that for general purposes this uncertainty may be neglected. "As to the exact position which the great names of Bunyan and Defoe hold," he says, "difference may be agreed to with resignation. What is certain is that about the beginning of the second quarter of the eighteenth century, the period immediately succeeding the appearance of Defoe's work, there began a development of the prose novel, and that this, partly though by no means wholly owing to one group of great writers in the style, had made very great progress by the beginning of the third, about which time we find Lady 
Mary Wortley Mantagu ${ }^{1}$ in Italy receiving boxes full of new novels from her daughter in England."2

The idea of social and political equality, too, was taking root even before the middle of the century. Common men made their voices heard around the world when they declared, in 1776, "All men are created equal"; and a little later, "A Man's a Man for A' That." But mutterings of dissatisfaction were heard in England more than a quarter of a century before the violent outburst of emotion in America. The novels of Richardson, Fielding, Sterne, and Goldsmith furnished a new and practicable outlet for pent up feelings. The dignity and worth of the average man, once recognized, put him in readiness to take a stand for what he conceived himself to be: an individual with many rights hitherto not recognized. But before all this could come to pass, the social structure had to be changed, or, at least, the ideas then current had to be superseded by ideals of vastly broader range and sweep. Here was the great chance for fiction. "It was by no accident" then, as Professor Phelps says, "that the novel was born at that time."3

Before the middle of the century the theatre had in large measure lost its hold on English life and thought. The drama was soon in such a decadent condition that it no longer satisfied either those who loved to see plays on the stage or those who loved merely to read them. The public was ready and eager, therefore, to welcome new forms of literary expression. The close relation of the drama to the novel in some matters of structure and purpose, made transition from the former to the latter natural and easy.

But the overthrow of the drama was not sudden, for the reason that in giving way to the novel, it was clinging to traditional rights that had long been established. It was thus some years after the rise of the novel before authors themselves made due discrimination between these two types. As late as 1764, Walpole declared in his preface to "The Castle of Otranto": "Everything tends directly to the catastrophe. Never is the reader's attention relaxed. The

1. See her "Letters to the Countess of Bute," dated, Louvre, Dec. 24, 1750,

2. George Saintsbury, "A Short HIstory of English Literature",p. 598.

3. Willam Lyon Phelps, "The Advance of the English Novel," p. 29. 
rules of the drama are almost observed throughout the conduct of the piece." Indeed the rules of the classic drama were always dogging the heels of the novelist. Some of Fielding's plays were failures on the stage, because they too nearly resembled novels. ${ }^{1}$ Richardson preferred to call his "Clarissa Harlowe" a dramatic narrative; and both he and Fielding appended lists of the "principal persons." "It is," says Professor Raleigh, "as if the novel were merely a play with its framework of stage directions expanded for the ease of the reader. And in this form the novel was bound to supplant the play with the reading public. . . A new form of literature that had all the interest of the drama, but imposed only the slenderest tax on the reader's attention and imagination, was predestined to success."2

The highly developed moralizing tendency of the drama continued its hold upon the novelists because public taste demanded it. From Richardson to the end of the century, authors felt a pressure from without, which made it inevitable for them to acquire the homiletic habit. The eighteenth-century drama was a ready means of inspiration and guidance in this respect. The influence of Steele's "Conscious Lovers," strictly a moral disquisition, can be easily traced in its effect upon Richardson.

Isabella, admonishing her niece Indianna about placing too much confidence in the words of a fashionable man, says, "Ay, do, persist in your credulity! flatter yourself that a man of his figure and fortune will make himself the jest of the town, and marry a handsome beggar for love."

"The town!" Indianna retorts, "I must tell you madam, the fools that laugh at Mr. Bevil will but make themselves more ridiculous; his actions are the result of thinking, and he has sense enough to make even virtue fashionable."3 This is exactly what Richardson tried to do.

Fielding ridiculed the reading public because of its inordinate desire for moralizing. He thought that this highly developed preference tended strongly toward a preverted literary tast: Joseph was tied in his host's upper chamber to

1. See W. L. Cross, "The History of Henry Flelding," I, p. 171.

2. Walter Ralelgh, "The English Novel," p. 142.

9. "The Conscious Lovers," Act II, Sc. II. 
one of the bed-posts, and Adams to the opposite one. While Joseph was brooding over the loss of his dear Betty, he burst out into a soliloquy; when asked by Adams what stuff he was repeating, the sighing lover replied that they were some lines he had got by heart out of a play. "Aye," said Adams, "there is nothing but heathenism to be learned from plays. I never heard of any fit for a Christian to read but "Cato" and "The Conscious Lovers"; and, I must own, in the latter there are some things almost solemn enough for a sermon."1

"As the democratic ideas of the Reformation more and more prevailed in English life in the seventeenth and eighteenth centuries," says Professor Cross, "the drama came under their influence; and before Richardson wrote, it had become thoroughly bourgeois. What interested an age which drove a king into exile and whose fathers had beheaded another, was not the crash of a royal house, nor the passions of kings and princes, but the pathos of everyday life; and it demanded of the playwright the familiar "domestica facta." Terror was banished from tragedy, and wit and humor from comedy, and their places were taken by long-drawn-out scenes of distress. As a consequence, the drama lost its rapid movement, and soon ceased to be at all. Dramatic representations continued, but where they were not melodramas or imitations of Restoration comedy, they were, in their slow development of plot, their analysis, and their moralizing, either essays in dramatic form, or already sentimental novels, rather than tragedies or comedies. The novelist was thus from one point of view but continuing a process that had already begun."2

The decay of the drama at this time was inevitable because of its limited range. It seemed incumbent upon the author now to include every aspect of human experience. The "Art of Life," from childhood to old age, which Fielding set out to describe in his novels, was too broad and too inclusive a thing for his plays. He had spent the best years of his life writing drama before he came to write

1. "Joseph Andrews," Bk. III, Ch. xi.

2. W. L. Cross, "The Development of the Englioh Novel," p. 89. 
"Tom Jones"; he ceased writing plays because it seemed advisable to do so. Reasons other than the closing of his theater forced him to forsake the drama for newer and fresher ventures in literary art.

The truth was, first, that more advanced ideas of life were to be conveyed; and second, that it was desired to reach a much wider reading public than was accustomed to attend theatrical performances. The drama proved to be inadequate, therefore, both in scope and in purpose. Moreover, "The Novel," says Professor Hamilton, "is far more serviceable than the drama as a medium for exhibiting the gradual growth of character,-the development of personality under influences extending over long periods of time and exerted in many different places."1 The time had come when the attention had to be focussed upon individuals as against nations. The growing, developing personality of the individual the drama could not portray. This limitation alone would have foredoomed the drama by the middle of the eighteenth century. Its decay was gradual but inevitable. The modern novel, the most important achievment of the period, was erected upon its ruins. ${ }^{2}$

The essay and the novel of the eighteenth century reveal many characteristics in common. The personal essays of Addison and Steele show a close relation to the new type. "That the essay and its branch form, the character sketch, . . . . were contributing to the Novel's development, is sure," says Professor Burton. "The essay set a new model for easy, colloquial speech: just the manner for fiction which was to report the accent of contemporary society in its average utterance. And the sketch, seen in its delightful efflorescence in Sir Roger De Coverly papers series by Addison, is fiction in a sense: differing therefrom in its slighter framework, and the aim of the writer, which first of all is the delicate delineation of personality, not plot and the study of the social complex. . . . A wide survey of the English essay from its inception with Bacon in the early

1. Clayton Hamilton, "Materials and Methods of Flctlon" p. 169.

2. See Sidney Lanier, "The English Novel," D. 267. 
seventeenth century will impress the inquirer with its fluid nature and natural outflow into full-fledged fiction."1

In so far as the character-sketch was concerned, Richardson and Fielding added very little. They found it fully developed in Addison's and in Steele's essays, and they followed closely the methods used by the essayists. Indeed they could hardly have done otherwise, for those vivid delineations exactly suited their purpose, namely the individualization of their fellow countrymen. "The dreary Character of the seventeenth century, which would have rendered Sir Roger as 'An Old Country Knight,' and Will Honeycomb as 'A Mere Town Gallant,' " says Professor Raleigh, "has received his death-blow in these (essay) sketches, drawn by men who loved the individual better than the type, and delighted in precisely those touches of character, eccentricities and surprises, that gave life to a literary portrait. The keen undiscriminating satire of the generic description has given way to the gentle atmosphere of humor that envelopes and illumines the character of Sir Roger, disarming the dogmatist by showing him that this man's very faults were loveable, and that his virtues may be smiled at as well as praised."2

No one can read Fielding's characterizations of squire Western without perceiving that Sir Roger de Coverly-the lover of the hunt-must have been the prototype. One day the squire was pursuing his daughter who had fled from his roof. He was zealous and eager to overtake her; but on this fine morning attachment to his hounds proved stronger than affection for his daughter Sophia:

"In this (Worcester) road he proceeded about two miles, when he began to bemoan himself most bitterly, frequently crying out, 'What pity is it! Sure never was so unlucky a dog as myself!' And then burst forth a volley of oaths and execrations."

When the parson tried to comfort him with the hope that he might soon overtake his daughter, the squire replied:

1. Ricliard Burton, "Masters of the English Novel," pp. 7-8.

2. Walter Raleigh, "The English Novel," pp. 121-122. 
" Pogh! d-n the slut! I am lamenting the loss of so fine a morning for hunting. It is confounded hard to lose one of the best scenting days, in all appearance, which hath been this season, and especially after so long a frost." "1

The yelping of the hounds is too much for him. At the signal, he turns from the road and dashes after them.

The character of the narrative element, especially in the first novels of Richardson and Fielding, resembles very closely that of the essay. There is very little plot in the essay narratives and usually there are no traces of plan. Richardson frankly admitted that he wrote without definite plan: "I am a very irregular writer," he wrote to Lady Bradshaigh, "can form no plan, nor write after what I preconceived," The plots of most of the earlier novels of the period were loosely constructed; and some of them consisted merely of a series of incidents joined by a single character. Smollett's "Roderick Random" is a fair example of the loose plots of the period.

The nature of the material, too, shows that the influence of the essay was very potent on the novel in its early stages of development. Addison and Steele, especially the latter, set the pace for moralizing. Novelists caught the step at once, and slightly quickened it as they proceeded. Richardson admits as much when, speaking through Grandma Shirley, he reminds the young ladies that, because of the kind of reading now in fashion, they have fallen into happier days than was her lot when she was a girl of sixteen. He makes her say furthermore: "The present age is greatly obligated to the authors of the Spectators."2

When he began writing the series of Familiar Letters "to instruct handsome girls, who were obliged to go out to service ... how to avoid the snares that might be laid against their virtue," Richardson said that this story (Pamela), which he had heard many years before, recurred to his mind. In all, he said, he had been thinking of such a story for nearly thirty years. The similarity of his first story to the one that had appeared in the Spectator about twenty-eight years before the publication of "Pamela,"

1. "Tom Jones," Bk. XII, Ch. 11.

2. "Sir Charles Grandison," VIII, Letter xiv. 
shows that he probably got his first clew from the essay narrative. It is quoted in full because of its interest when compared with the Pamela story:

Saturday, May 10, 1712.

"I have more than once had occasion to mention a noble saying of Seneca the philosopher, that a virtuous person struggling with misfortunes, and rising above them, is an object on which the gods themselves may look down with delight. I shall therefore set before my reader a scene of this kind of distress in private life, for the speculation of this day.

"An eminent citizen, who had lived in good fashion and credit, was by a train of accidents, and by an unavoideble perplexity in his affairs, reduced to a low condition, which made him rather choose to reduce his manner of living to his present circumstances than solicit his friends in order to support the show of an estate when the substance was gone. His wife, who was a woman of sense and virtue, behaved herself on this occasion with uncommon decency, and never appeared so amiable in his eyes as now. Instead of upbraiding him with the ample fortune she had brought, or the many great offers she had refused for his sake, she redoubled all the instances of her affection, while her husband was continually pouring out his heart to her in complaints that he had ruined the best woman in the world. He sometimes came home at a time when she did not expect him, and surprised her in tears, which she endeavoured to conceal, and always put on an air of cheerfulness to receive him. To lessen their expense, their eldest daughter (whom I shall call Amanda) was sent into the country, to the house of an honest farmer, who had married a servant of the family. The young woman was apprehensive of the ruin which was approaching, and had privately engaged a friend in the neighborhood to give her an account of what passed from time to time in her father's affairs. Amanda was in the bloom of her beauty; when the lord of the manor, who often called in at the farmer's house as he followed his country sports, fell passionately in love with her. He was a man of great generosity, but from a loose education had constructed a hearty aversion to marriage. He therefore entertained a design upon Amanda's virtue, which at present he thought fit to keep private. The innocent creature, who never suspected his intentions, was 
pleased with his person; and having observed his growing passion for her, hoped by so advantageous a match she might quickly be in a capacity of supporting her impoverished relations. One day as he called to see her he found her in tears over a letter she had just received from her friend, which gave an account that her father had lately been stripped of every thing by an execution. The lover, who with some difficulty found out the cause of her grief, took this occasion to make her a proposal. It is impossible to express Amanda's confusion, when she found his pretentions were not honourable. She was now deserted of all her hopes, and had no power to speak; but rushing from him in this utmost disturbance. locked herself in her chamber. He immediately dispatched a messenger to her father with the following letter:

"Sir,

" 'I have heard of your misfortune, and have offered your daughter, if she will live with me, to settle on her four hundred pounds a year, and to lay down the sum for which you are now distressed. I will be so ingenuous as to tell you that I do not intend marriage; but, if you are wise, you will use your authority with her not to be too nice, when she has an opportunity of saving you and your family, and of making herself happy.

$$
\text { 'I am, \&c.' }
$$

"This letter came to the hands of Amanda's mother;' she opened and read it with great surprise and concern. She did not think it proper to explain herself to the messenger, but desiring him to call again the next morning, she wrote to her daughter as follows:

"Dearest Child,

"Your father and I have received a letter from a gentleman, who pretends love to you, with a proposal that insults our misfortunes, and would throw us to a lower degree of misery than any thing which is come upon us. How could this barbarous man think that the tenderest of parents would be tempted to supply their wants by giving up the best of children to infamy and ruin? It is a mean and cruel artifice to make this proposal at a time when he thinks our necessities must compel us to any thing; but we will not eat the bread of shame; and therefore we charge thee not to think of us, but to avoid the snare which is laid for thy virtue. 
Beware of pitying us; it is not so bad as you, perhaps, have been told. All things will yet be well, and I shall write my child better news.

"I have been interrupted; I know not how I was moved to say things would mend. As I was going on, I was startled by the noise of one that knocked at the door, and hath brought us an unexpected supply of debt which had long been owing. Oh! I will now tell thee all. It is some days I have lived almost without support, having conveyed what little money I could raise to your poor father. Thou wilt weep to think where he is, yet be assured he will soon be at liberty. That cruel letter would have broken his heart, but I have concealed it from him. I have no companion at present besides little Fanny, who stands watching my looks as I write, and is crying for her sister. She says she is sure you are not well, having discovered that my present trouble is about you. But do not think I would thus repeat my sorrows to grieve thee. No, it is to entreat thee not to make them insupportable, by adding what would be worse than all. Let us bear cheerfully an affliction, which we have not brought on ourselves, and remember there is a Power who can better deliver us out of it, than by the loss of thy innocence. Heaven preserve my dear child!

$$
\text { 'Thy affectionate mother, }
$$

"The messenger, notwithstanding he promised to deliver this letter to Amanda, carried it first to his master, who he imagined would be glad to have an opportunity of giving it into her hands himself. His master was impatient to know the success of his proposal, and therefore broke open the letter privately to see the contents. He was not a little moved at so true a picture of virtue in distress; but at the same time, was infinitely surprised to find his offers rejected. However he resolved not to suppress the letter, but carefully sealed it up again, and carried it to Amanda. All his endeavours to see her were in vain, till she was assured he brought a letter from her mother. $\mathrm{He}$ would not part with it but upon condition that she would read it without leaving the room. While she was perusing it, he fixed his eyes on her face with the deepest attention. Her concern gave a new softness to her beauty; and when she burst into tears, he could no longer refrain from bearing a part of her sorrow, and telling her, that he too had read the letter, and was 
resolved to make reparation for having been the occasion of it. My reader will not be displeased to see the second epistle which he wrote to Amanda's mother:-

" 'Madam,

"' I am full of shame, and will never forgive myself if I have not your pardon for what I lately wrote. It was far from my intention to add trouble to the afflicted; nor could any thing, but my being a stranger to you, have betrayed me into a fault, for which, if I live, I shall endeavour to make amends, as a son. You cannot be unhappy while Amanda is your daughter; nor shall be, if any thing can prevent it, which is in the power of,

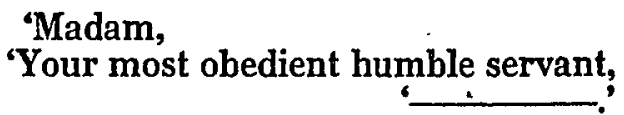

"This letter he sent by his steward. and soon after went up to town himself to complete the generous act he had now resolved on. By his friendship and assistance Amanda's father was quickly in a condition of retrieving his perplexed affairs. To conclude, he married Amanda, and enjoyed the double satisfaction of having restored a worthy family to their former prosperity, and of making himself happy by an alliance to their virtues."1

Any one familiar with "Pamela" will detect at once the likeness between these two stories. Here are the poor parents, honest to the core, but by a reverse of fortune reduced to poverty. To relieve their distress, the eldest daughter, comely and beautiful, is sent into the country where a rich lord of the manor falls passionately in love with her. $\mathrm{He}$ has a natural aversion to marriage, and consequently entertains base designs against her virtue. She is much pleased with his person, and, not suspecting his pruriency, quietly encourages his advances. She is willing to play for an advantageous match, which will enable her to support her relatives. She receives a letter from her parents which reminds her of their distress. The tears gush out. In this manner she creates the pathos by which she hopes to arouse her lover's sympathy, and thus hasten the nuptials. It

1. "The Spectator," No. 375. 
works. More letters, which the lover intercepts, are allowed to pass between the young woman and her parents. The lord of the manor marries the young nymph, because she has succeeded in preserving her virtue as pure and white as new fallen snow. The parents are raised at once to a position of affluence, and all are happy. Here is the subject matter of Samuel Richardson's "Pamela," the first novel of character.

Another essay narrative that bears an equally close resemblance to the novel is Addison's "Vision of Mirza." It appears that Johnson appropriated the theme and some of the subject matter of this story for his "Rasselas." Mirza ascends the hills of Bagdad in order to pass the day in meditation and prayer: "As I was here," he says, "I fell into a profound contemplation on the vanity of human life; and passing from one thought to another, 'Surely,' said I, 'man is but a shadow, and life a dream'." He then meets the Genius who lifts him from the ground and takes him by the hand and says, "Mirza, I have heard thee in thy soliloquies, follow me."

"He then led me to the highest pinnacle of the rock, and placing me on top of it, 'Cast thy eyes eastward,' said he, 'and tell me what thou seest.' 'I see,' said I, 'a huge valley and a prodigious tide of water rolling through it.' 'The valley thou seest,' said he, 'is the Vale of Misery, and the tide of Eternity.' "

Over the bridge a great multitude were endeavoring to pass; but "hidden pit-falls were set very thick at the entrance of the bridge, so that throngs of people no sooner broke through the cloud, but many of them fell into them. They grew thinner toward the middle, but multiplied and lay close together toward the ends of the arches that were entire."

"There were indeed some persons, but their number was very small, that continued a kind of march on the broken arches, but fell through one after another, being quite tired and spent with so long a walk."

“'What mean,' said I, 'those great flights of birds that are perpetually hovering about the bridge, and settling 
upon it from time to time? I see vultures, harpies, ravens, cormorants, and among many other featherd creatures, several little winged boys, that perch in great numbers upon the middle arches.' 'These,' said the Genius, 'are Envy, Avarice, Superstition, Despair, Love, with like cares and passions that infest human life.'

"I here fetched a deep sigh. 'Alas!' said I, 'man was made in vain! how is he given away to misery and mortality! tortured in life and swallowed up in death." ",

Compare with the above the sentiments in "Rasselas." The Princess and her brother after long wandering in search of real happiness, at length returned to the banks of the Nile where they related the experiences of the day. "As they were sitting together the Princess cast her eyes upon the river that flowed before her. 'Answer,' said she, 'great father of waters, thou that rollest thy floods through eighty nations, to the invocations of the daughter of thy native king. Tell me if thou waterest in all thy course a single habitation from which thou dost not hear the murmurs of complaint.'"

"' 'You are then,' said Rasselas, 'not more successful in private houses than I have been in courts.' 'I have,' . . . . said the Princess, 'enabled myself to enter familiarly into many families, where there was the fairest show of prosperity and peace, and know not one house that is not haunted by some fury that destroys their quiet." "s2

" "Those that lie here stretched before us, the wise and the powerful of ancient times, warn us to remember the shortness of our present state; they were perhaps snatched away while they were busy, like us, in the "choice of life"." "3

"Of those wishes they had formed they well knew that none could be obtained."4

"Just a year before completing his masterpiece," says Professor Whiteford, "Addison composed "The Vision of Mirza,' in the "Spectator," in which is the oriental bridge on

1. "The Spectator," No. 159.

2. "Rasselas," Ch. Xxv.

3. "Ibid.," Ch. xlvili.

4. "Ibld.", Ch. xlix. 
THE EIGHTEENTH-CENTURY NOVEL

which Samuel Johnson built his "Rasselas" (1759). No happiness came to any mortal who tried to cross the arches erected in the hollow valley of Bagdad, nor was it to be found in or outside of the Prince of Abyssinia's happy val ley."1

The art of letter-writing, so highly developed in the eighteenth century, also contributed much to the development of the novel. The letters of Richardson, Lady Mary Wortley Mantagu, and Horace Walpole are today universally recognized as literature. Before the middle of the eighteenth century, these letters were supplying topics for conversation and scenes from familiar life that were almost exact counterparts of those we find a little later in the novel. "Letter-writing," says Miss Thompson, "was, in fact, regarded as an art, and letters seemed to have filled in some degree the part played by the magazine or the newspaper of today; they were passed round from house to house, copied and recopied, and read over and over again on long winter evenings and in quiet country places where any message from the outside world was acceptable."2

Richardson himself loved to indite letters so much that he wrote three long novels in the epistolary style. He prized the art so highly that he usually made the charms of his heroines conspicious in proportion to their ability as letterwriters. "I have seen more of your letters than you imagine," Mr. B. informed Pamela, adding, "and am quite overcome with your charming manner of writing, so free, so easy .... "3 "You, Madam," Emily Jervois wrote to Harriet Byron, " are 'such' a writer, and I am such a 'poor thing' at my pen!-But I know you will accept the heart. And so my very diffidence shows pride; since it cannot be expected from me to be a fine writer. And yet this very letter, I foresee, will be the worse for my diffidence, and not the better: for I don't like this beginning neither-But come, it shall go."4 Lovelace delights in writing: Whether at Lord M's, or Lady Betty's or Lady Sarah's, he has always a pen in his fingers when he retires. One of his compan-

\footnotetext{
1. Robert Naylor Whiteford, "Motives in English Flction," p. 88.

2. Clara L. Thompson, "Samuel Richardson," pp. 144-145.

3. "Pamela," I, Letter XXX.

4. "Sir Charles Grandison," IV, Letter xxxix.
} 
ions (confirming his love of writing) has told her (Mrs. Fortesque) that his thoughts flow rapidly to his pen."1 Both Pamela and Clarissa kept "memorandums" of all their letters.

"That you and I, my dear, should love to write, is no wonder," Miss Howe wrote to Clarissa, and added: "We have always, from the time each could hold a pen, delighted in epistolary correspondencies."2 "Early familiar Letterwriting," Richardson declared in 'Clarissa,' "is one of the greatest openers and improvers of the mind that man or woman can be employed in." And the author explains in the preface just why this is so: first, these letters are "between two young ladies of virtue and honor, bearing an inviolable frierdship for each other;" second, they write "not merely for amusement, but upon the most interesting' subjects;" and third, each has the knack of writing a style that is very "lively and affecting," sometimes approximating "strokes of gaiety, fancy and humor."3

Richardson's long practice in letter-writing explains only in part his reason for choosing the epistolary method; for he certainly discovered in the personal, friendship letter of his time some characteristics that soon proved to be elementary and fundamental in the new art. But those characteristics were just as important in developing the novel subsequently, no matter which method of telling the story was used. First, eighteenth-century epistles were full of admirable character-sketches. This was true not only of private correspondence, but also of those letters that appeared in the essay. "To them (Addison and Steele) belong the credit of discovering that the epistle could become a picturesque type of character-sketch."4 One reason why the novel was so interesting and popular in the eighteenth century was the fact that readers were given pictures of those men and women whose exact counterpart they had seen in actual life. Richardson succeeded in individualizing the sketches in his novel-letters largely by the process of introspection. "The letters and conversations,

1. "Clarissa Harlowe," I, Letter xil.

2. "Ibld""

3. "Preface to Clarissa Harlowe."

4. "Cambridge History of English Literature," IX, p. 67. 
THE EIGHTEENTH-CENTURY NOVEL

where the story makes the slowest progress, are presumed to be "characteristic'," he says in his postscript to "Clarrissa," and adds: "They give occasion, likewise, to suggest many interesting personalities."1

Again, the subject matter of familiar, personal letters was almost exactly the same as that which Richardson put into the letters of his novels. The letters, he told his readers, are upon the most "interesting" subjects; and that they are "occasionally interspersed with such delicacy of sentiment, particularly with regard to the other sex; such instances of impartiality, each freely, as a fundamental principle of their friendship, blaming, praising, and setting right the other as are strongly to be recommended. . . ."2 In this respect, the letter did much to bring the novel closer to life, since one of the characteristics of private letters is the revelation, conscious or unconscious, of the secrets of private life. Novelists no doubt discovered this natural element in the eighteenth-century letter; and they used it at least for the purpose of making the sentiments, aimed directly at instruction, look natural and plausible.

Then too the letter is very closely allied to the soliloquy. And of course some such device as this was useful, not only as a natural transition from the drama then decaying, but also for dramatic effect. "The letters are written," says Richardson, "while the heart of the writers must be supposed to be wholly engaged in their subjects." "The events of the time," he says, "are generally dubious," thus giving rise to "critical situations." " 'Instantaneous' descriptions and reflections" must be written down "in the height of 'present' distress."3 The dramatic character of Richardson's letters in "Pamela," and especially in "Clarissa Harlowe," reminds one forcibly of Browning's Dramatic Monologues a century later. At some pinnacle moment of life, the character must decide at once for his weal or woe. There could be no better method of individualization than this, for each character is delineated from within outward-from the thought to the execution of it-every step completed before the eyes of the reader. "The very repetition which the

1. Postscript to "Clarissn Harlowe."

2. Preface to "Clarlssa Harlowe."

3. "IbId." 
(letter) method involves," says Richardson's biographer, Miss Thompson, "gives wonderful definiteness to the characterization."

The decay of the drama through the second quarter of the eighteenth century, made possible a more intense study of character because of the greater range of the novel; for in this type there could be depicted a growing, developing personality. The essay furnished admirable topics for conversation and instruction. Generally moral in tone, the gentle satire of the essay directed attention to practical, homely affairs. The prose love-story in its infancy and the character-sketch well developed were ready to the novelist's hand. The familiar letter suggested a great variety of subjects-personal, domestic, social, religious, political-subjects that were live, vital, and timely. And the soliloquy, in its dramatic effect, greatly aided in the revelation of the inner life and character.

"The novel of personal life, of individual, separate, domestic life," says Professor Stoddard, "is the basal form." In the second quarter of the eighteenth century this basal form had its beginning, because the times were ripe for it. 


\section{CHAPTER II}

RISE OF THE MODERN NOVEL: CRYSTALLIZATION OF THEORY

The author of "Pamela" informs us that the origin of this novel was "owing to an accident"; but there is evidence that even before he had completed the first part of. it, he was aware of having created a new kind of writing. Six years after this innovation in English fiction, Richardson wrote to his friend Aron Hill, admitting his consciousness of the fact while writing the book, that he was intro ducing something new. "Little did I think at first, of making one much less two volumes of it. ... I thought the story, if written in an easy and natural manner, suitable to the simplicity of it, might possibly introduce a new species of writing. ..." Encouraged by the success of the first part, he deemed it wise to refer briefly in his preface to the second part of what doubtless had seemed strange. He hoped that his readers would discover, in the second part as in the first, "rules, equally new and practicable, inculcated, throughout the whole, for the general conduct of life."2

No doubt Henry Fielding was more conscious of his art in his first novel, "Joseph Andrews," than was the author of "Pamela" in his. This "lewd and ungenerous engraftment," as Richardson pronounced it, had converted the prudent, virtuous Pamela, into a scheming, selfish Shamela. But Fielding, true artist that he was, could not long continue the parody; for he very soon discovered to his gratification that his book was beginning to differ in important particulars from the first novel. "As it is possible the mere English reader may have a different idea of romance with the author of these little volumes," he writes in the preface, "and may consequently expect a kind of entertainment not to be found, nor which was even intended, in the following pages, it may not be improper to premise a few words

1. Barbauld, "Correspondence of Richardson," I, p. lroxill.

2. "Pamela," Preface to the Second Part. 
concerning this kind of writing, which I do not remember to have seen hitherto attempted in our language."1 Referring to the character of Adams, he says, "As it is the most glaring in the whole, so I conceive it is not to be found in any book now extant."2

Undoubtedly Fielding at first had intended "Joseph Andrews" for burlesque, which he certainly carried through the first several chapters. Had he continued thus, there would have been nothing new; but when it turned out to be "a comic epic poem in prose," some explanation by the author was necessary. "From Chapter XI., which deals with 'several new matters not expected," says Professor Raleigh, "it becomes a novel of adventure of a type new to English literature. So that when Fielding came to write his preface he found that he too had to defend and explain a kind of writing hitherto unattempted."3

Horace Walpole declared in his preface to the second edition of "The Castle of Otranto," nearly a quarter of a century after "Pamela," that he had attempted to blend two kinds of romance, the ancient and the modern. And if he was not more in sympathy with the new novel than with the old romance, he was certainly forced by public opinion to feign so. In a letter to Elie de Beaumont, March 18, 1765, he wrote: "To tell you the truth, it was not so much my intention to recall the exploded marvels of the ancient romance as to blend the wonderful of old stories with the natural of modern novels."4 Miss Burney considered novel-reading "incurable" by 1778, and in her preface to "Evelina" she franlkly prepared for disappointment all those reader who might be entertaining the gentle expectation of finding anything in her novel that savored of the old romance.

Literary taste had been formed very largely by Augustan canons of criticism, with which the first English novelists were in perfect accord. This novel kind of writing, therefore, was not shockingly new to readers, but it was

\footnotetext{
1. Preface to "Joseph Andrews."

2. "Ibld."

3. Walter Ralelgh, "The English Novel," pp. 164-165

4. Cunningham, "Letters of Horace Walpole," IV, p. 339.
} 
rather a soothing surprise; very soon they accepted it as embodying the highest reaches of English thought and emotion. Aaron Hill, upon reading "Pamela" for the first time, though he asserts he did not know its authorship, expressed in a letter his surprise and unbounded satisfaction: "Who could have dreamed," he wrote, "he should find, under the modest disguise of a novel, all the soul of religion, good breeding, discretion, good nature, wit, fancy, fine thought, and morality?"'

Grandma Shirley admirably summed up the opinion of the respectable middle class of readers in a conversation with several yong ladies at Shirley Manor: "The reading in fashion, when I was young, was romances. You, my children, have, in that respect, fallen into happier days. The present age is greatly obliged to the authors of the Spectators. But till I became acquainted with my dear Mrs. Eggleton, which was about my sixtieth year, I was over-run with the absurdities of that unnatural kind of writing."2

The first great novelists of the eighteenth century, therefore, were the originators and sponsors of a new kind of writing; new not only in form, but in content as well. The popularity of "Pamela" and of "Joseph Andrews" indicates that the audiences were pleased with this new type of literature. "Richardson's novel ('Pamela')," says Professor Cross, "ran its course down through all classes to the servants' hall, while Fielding's novel ('Joseph Andrews') ran upward through a less numerous class to the gentry and nobility." It is evident that all classes of society from the highest to the lowest-from the billage blacksmith to the gallant gentleman, and from waiting maids to the fine ladies of Ranelagh-eagerly read and discussed with each other the contents of these books.

The first great novelists of the mid-eighteenth century were incessant and insistent in denouncing the old romance as dangerous and unworthy of perusal by the reading public. These authors had introduced something new; and, after they had largely succeeded in making their audiences agree that "happier days" had come along with the new

1. Barbauld, "Correspondence of Rtchardson," I, pp. 54-55.

3. "W. L. Cross, "The History of Henry Fleldung," I, p. 355. 
type, they freely pointed out the fundamental differences between the new and the old. These differences led to the formulation of general constructive theories which, though crude and more or less indefinite then, may be comprehended now under four broad principles.

I. The piece should profess and disclose a moral purpose, as against a purely fictitious narrative designed solely for entertainment. II. The characters, the conversations, the situations, and the incidents should have their basis in human nature; should evolve from a close study of real life-of contemporary English life-as against the far-off unknown people of distant lands, and ancient times. III. Reason and common sense should predominate always, as against mystic ideality, the highly imaginative, and the purely fanciful. IV. The plot, the persons, and the machinery of the piece should come well within the bounds of probability, and easily within the range of credibility, thereby dismissing the absurd and marvelous of ancient romance.

Scott called Fielding the "Father of the English Novel," because he was the first to transform loose adventure into a new art. Whether or not we agree with Scott without some reservations, makes little difference; the fact is, Fielding was certainly the first to grasp the principles underlying the new prose fiction and to give then utterance in comprehensive manner. This he did in "Tom Jones" in 1749. I have quoted them at length because they are significant as theory in moulding the novel later, and because they come from an artist at so early a date:

"As we are now entering upon a book in which the cause of our history will oblige us to relate some matters of a more strange and surprising kind than any which hitherto occurred, it may not be amiss, in the prolegomenous or introductory chapter, to say something of that species of writing which is called the marvellous. To this we shall, as well for the sake of ourselves as for others, endeavor to set some certain bounds, and indeed nothing can be more necessary as critics (by this word here ... we mean every reader in the world) of different complexions are here apt to run into very different extremes. . . 
"First, then, I think it may very reasonably be required of every writer that he keeps within the bounds of possibility; and still remembers that what it is not possible for men to perform, it is scarce possible for man to believe he did perform. ...."

"The only supernatural agents which can in any manner be allowed to us moderns are ghosts; but of these I would advise an author to be extremely sparing. These are, indeed, like arsenic, and other dangerous drugs in physic, to be used with the utmost caution; nor would I advise the introduction of them at all in the works, or by those authors, to which, or to whom, a horse-laugh in the reader would be any great prejudice or mortification. ..."

"Man, therefore, is the highest subject (unless on very extraordinary occasions indeed) which presents itself to the pen of our historian or of our poet; and, in relating his actions, great care is to be taken that we do not exceed the capacity of the agent we describe.

"Nor is possibility alone sufficient to justify us; we must keep likewise within the rules of probability. It is, I think, the opinion of Aristotle; or if not, it is the opinion of some wise man, whose authority will be as weighty when it is as old, 'That it is no excuse for a poet who relates what is incredible, that the thing related is really matter of fact'... .

"Such facts, however, as they occur in the thread of the story, nay, indeed, as they constitute the essential parts of it, the historian is not justfiable in recording as they really happen, but, indeed, would be unpardonable should he omit or alter them. ...

"To say the truth, if the historian will confine himself to what really happened, and utterly reject any circumstances, which, though never so well attested, he must be well assured is false, he will sometimes fall into the marvellous, but never into the incredible. He will often raise the wonder and surprise of his reader, but never that incredulous hatred mentioned by Horace. It is by falling into fiction, therefore, that we generally offend against this rule, of deserting probability, which the historian seldom, if ever, quits till he forsakes his character and commences a writer of romance. In this, however, those historians who relate public transactions, have the advantage of us who confine ourselves to scenes of private life.... 
"But we who deal in private character, who search into the most retired recesses, and draw forth examples of virtue and vice from holes and corners of the world, are in a more dangerous situation. As we have no public notoriety, no concurrent testimony, no record to support and corroborate what we deliver, it becomes us to keep within the limits not only of possibility, but of probability too; and this more especially in painting what is greatly good and amiable. ..."

"In the last place, the actions should be such as may not only be within the compass of human agency, and which human agents may probably be supposed to do; but they should be likely for the very actors and characters themselves to have performed; for what may be only wonderful and surprising in one man, may becorne improbable, or indeed impossible, when related of another.

"This last requisite is what the dramatic critics call conservation of character: and it requires a very extraordinary degree of judoment, and a most exact knowledge of human nature."1

Fielding did possess just such an exact knowledge of human nature. "Fielding's novels are, in general, thoroughly his own; and they are thoroughly English," says Mr. Hazlitt. "What they are most remarkable for, is neither sentiment, nor imagination, nor wit, nor even humor, though there is an immense deal of this last quality; but profound knowledge of human nature, at least English nature, and masterly pictures of the characters of men as he saw them existing." 2

The phenomenal success of the first part of "Pamela," which greatly exceeded the author's "most sanguine expectations," made Richardson eager to offer more of the same stuff; he commended the second part to his readers in these words: "The Editor hopes, that the Letters which compose this Part will be found equally written to Nature, avoiding all romantic flights, improbable surprises, and irrational machinery. ..."3

"He (the Editor) always thought that 'sudden conver-

1. "Tom Jones," Bk, vIIr, Ch. i.

2. William Hazittt, "English Comlc Writers," Lecture VI, pp. 151-152.

3. "Pamela." Preface to the Second Part. 
sions,' such especially, as were left to the candour of the reader to 'suppose' and 'make out,' had neither art, nor nature, nor even 'probability' in them; and that they were, moreover, of very 'bad' example."1

Fielding, too, was opposed to sudden conversions, and for the same reasons. "Our modern authors of comedy," he says, "have fallen almost universally into the error here hinted at; their heroes generally are notorious rogues, and their heroines abandoned jades, during the first four acts; but in the fifth, the former become very worthy gentlemen, and the latter women of virtue and discretion; nor is the writer often so kind as to give himself the least trouble to reconcile or account for the monstrous change and incongruity. There is, indeed, no other reason to be assigned for it, than because the play is drawing to a conclusion; as if it was no less natural in a rogue to repent in the last act of a play than in the last of his life. ..."2

Much has been written in criticism of Richardson's prolixity, which, it is asserted, is due largely to the epistolary method of telling the story. Curiously enough, the author anticipated this objection to his books, and was ready with his reply when the objection came. It is not strange, or by accident, that the astute author justified the excessive length almost solely on the ground that the book was according to reason-credible and probable. On this head he quotes from a "Critique on the History of Clarissa," "the opinion of an ingenius and candid foreigner, on this manner of writing, who," his vanity prompts him to assert, "has done great honor in it to the "History of Clarissa" ":

" 'Romances in general. . . . are wholely improbable; because they suppose the History to be written after the series of events is closed by the catastophe: a circumstance which implies a strength of memory beyond all examples and probability in the persons concerned, enabling them, at the distance of several years, to relate all the particulars of a transient conversation: or rather it implies a yet more im-

1. Postseript to "Clarissa Harlowe,"

2. "Tom Jones," Bk. Ch. 1 . 
probable confidence and familiarity between all these persons and the author." "1 He justified himself in like sentiment when those who had been anticipating a mere novel or romance objected to the length of the piece: "To all which we may add, that there was frequently a necessity to be very circumstantial and minute, in order to preserve and maintain that air of probability, which is necessary to be maintained in a story designed to represent real life."2

Thus the stage was set. "In order to preserve and maintain that air of probability, which is necesary to be maintained"; that is, it was necessary because the Age of Pope, with all it implied, made it so. But the air of probability that was characteristic of the new fiction, did not go long unchallenged, for the story of the Middle Ages, composed of love, chivalry, and religion, with its absurdities and improbabilities, was not yet dead; it was only moribund. The hotly contested battle-royal between the forces of the new novel and those of the old romance was soon on; but there were, however, veiled suggestions of willingness to compromise the differences, beginning with Walpole's "Castle of Otranto" in 1764. The contest was prolonged through more than a quarter of a century in "The Old English Baron," in "The Mysteries of Udolpho," and in "Caleb Williams"; it ended in a drawn battle with the forces of the new type slightly stronger than those of the old romance when they merged into nineteenth-century romanticism.

There is evidence by 1760 of a determined reaction against the new novel that was reproducing photographically accurate pictures of the moral and social conditions of the times. There was danger that the English novel would continue little more than a mirror of contemporary life. To obviate this danger, Sterne disregarded the traditions; and, as a result of his boldness and in spite of the petty criticism of his times, he won liberty for all novelists who would follow.

Mr. Shandy and uncle Toby start downstairs: "Is it not a shame," he asks tauntingly, "to make two chapters of 
what passed in going down one pair of stairs? for we are got no farther yet than the first landing, and there are fifteen more steps down to the bottom; and, for aught I know as my father and my Uncle Toby are in a talking humor, there may be as many chapters as steps. Let that be as it will, Sir, I can no more help it than my destiny.A sudden impulse comes across me:-drop the curtain Shandy:-I drop it.-Strike a line here across the paper, Tristram:-I strike it,-and hey for a new chapter.

"The duce of any other rule have I to govern myself in this affair;-and if I had one,-as I do all things out of all rule,-I would twist and tear it to pieces, and throw it into the fire when I had done.-Am I worm? I am, and the cause demands it:-a pretty story! is a man to follow rules,-or rules to follow him?"1

"This chapter, therefore, I 'name' the chapter of Things,--and my next chapter to it, that is, the first chapter of my next volume, if I live, shall be my chapter upon Whiskers, in order to keep up some kind of connection in my works."2

Horace Walpole, who tells us frankly that he was fond of faction as an amusement and a lover of mischief, eagerly seized the opportunity to neglect rules. But even so, he did not dare exceed the bounds of probability without an apology and a feeble attempt to explain his innovation.

"It was an attempt to blend the two kinds of Romance, the ancient and the modern," he says in his preface to the second edition. "In the former, all was imagination and improbability: in the latter, nature is always intended to be, and sometimes has been, copied with success. Invention has not been wanting; but the ereat resources of fancy have been dammed un, by a strict adherence to common life. But if in the latter species Nature has cramped imagination, she did but take her revenge, having been totally excluded from old Romances. The actions, sentiments, conversations, of the heroes and heroines of ancient days, were as unnatural as the machines employed to put them in motion. 
"The author of the following pages thought it possible to reconcile the two kinds. Desirous of leaving the powers of fancy at liberty to expatiate through the boundless realm of invention, and thence of creating more interesting situations, he wished to conduct the moral agents in the drama according to the rules of probability; in short, to make them think, speak, and act, as it might be supposed mere men and women would do in extraordinary positions."1

Miss Clara Reeve, however, was not satisfied with Walpole's romance. She agreed with his theory, but thought that in practice he had greatly exceeded the bounds of probability; that he had not succeeded in writing the book he had promised. Accordingly she set out to correct him by writing what is known as "The Old English Baron."

" "The Castle of Otranto," " she says in her preface, "is an attempt to unite the various merits and graces of the ancient Romance and the modern Novel. To attain this end, there is required a sufficient degree of the marvelous to excite attention; enough of the manners of real life to give an air of probability to the work; and enough of the pathetic to engage the heart in its behalf." She continues:

"The book we have just mentioned is excellent in the last two points, but has a redundancy in the first. The opening excites the attention very strongly; the conduct of the story is artful and judicious; the characters are admirably drawn and supported; the diction polished and elegant; yet with all these brilliant advantages, it palls upon the mind (though it does not upon the ear); and the reason is obvious, the machinery is so violent that it destroys the effect it is intended to excite. Had the story been kept within the utmost 'verge' of probability, the effect had been preserved, without losing the least circumstance that excites or detains the attention.

"For instance; we can conceive, and allow of, the appearance of a ghost; we can even dispense with an enchanted sword and helmet; but then they must be kept within certain limits of credibility. A sword so large as to require a hundred men to lift it; a helmet that by its own weight forces a passage through a courtyard, into an arched vault big enough for a man

1. "Preface to "The Castle of Otranto." 
to go through; a picture that walks out of its frame; a skeleton ghost in a hermits cowl:-when your expectation is wound up to the highest pitch, these circumstances take it down with a witness, destroy the work of imagination, and instead of attention excite laughter....

"In the course of my observations upon this singular book, it seemed to me that it was possible to compose a work upon the same plan, wherein these defects might be avoided; and the 'keeping' as in 'painting,' might be preserved."1

This literary offspring of "The Castle of Otranto," then, was written upon the same plan, with a design to unite the most attractive and interesting circumstances of the ancient Romance and the modern Novel. To attain this end, she required, first, a sufficient degree of the marvelous to excite attention; and second, enough of the manners of real life to give an air of probability to the work. Walpole's romance palled upon her mind because the machinery was too violent-so violent as to destroy the very effects it was intended to excite. She set out, therefore, to keep her story within the utmost 'verge' of probability. Witness the curious situation she creates:

At nine o'clock Old Joseph gave Edmund a lamp and sword and conducted him to the haunted chamber for the night. Here he found the furniture decayed and the rats occupying the bed that the moths had all but devoured. Such conditions were not conductive to sleep. Espying two doors at the further side of the room, he resolved to examine them. The first of these opened with ease. He entered, satisfied his curiosity, and returned to the chamber to see where the other door led to. To his astonishment the key was rusted into the lock, and resisted his attempts. He set the lamp on the ground and exerted all his strength. The sudden yielding of the door caused a draught which instantly blew out the lamp and left him in utter darkness.

Thus far all goes well with Edmund; and the reader is pleased because his attention is arrested and his interest and curiosity are aroused. Indeed he is impatient to learn the

1. Preface to "The Old English Baron." 
outcome of this matter, and therefore willingly follows the author:

"At this same moment (when the light went out) he (Edmund) heard a hollow rustling noise, like that of a person coming through a pasage. Till this moment not one idea of fear had approached the mind of Edmund; but just then all the concurrent circumstances of his situation struck upon his heart, and gave him a new and disagreeable sensation. He paused awhile; and recollecting himself, cried out aloud, 'What should I fear? I have not wilfully offended God or man; why, then should I doubt protection? But I have not yet implored the Divine assistance; how then can I expect it?' Upon this he kneeled down and prayed earnestly, resigning himself wholly to the will of Heaven; while he was yet speaking his courage returned, and he resumed his usual confidence. Again he approached the door from whence the noise proceeded; he thought he saw a glimmering light upon the staircase before him. 'If,' said he, 'this apartment is haunted, I will use my endeavors to discover the cause of it; and if the spirit appears visibly, I will speak to it.'

"He was preparing to descend the staircase, when he heard several knoclss at the door. by which he first entered the room; and stepping backward, the door was clapped to with great violence. Again fear attacked him; but he resisted it, and boldly cried out, 'Who is there?'

"A voice at the outer door answered, 'It's I; Joseph, your friend.'

"What do you want?'

" 'I have brought you some wood to make a fire," said Joseph."1

If Walpole's absurd and incredible situations excite laughter, as Miss Reeve maintains, then, in justice to Walpole, we should say of Miss Reeve's professed literary offspring, that the farcial bathos of the situations she created suppresses our smiles.

Mrs. Radcliffe's method, though far more cleverly done, is similar to Miss Reeve's. Her work seems to abound in unusual and mysterious agencies which excite fear and great agony in her lonely, unprotected females; but in

1. "The Old English Baron," pp. 68-64. 
reality her means and agents are natural and human. She describes the fears and nervous hallucinations of her characters in a ghostly manner, and then explains them by natural causes. "The plots of her stories," says Professor Raleigh, "have of ten been censured for their timidity. With an unprecedented control over the secrets of terror, a power of awakening by a touch all the vague associations and suggestions of superstitious awe, she yet shrinks from following Walpole, and never plunges into the frankly supernatural. Further, and here perhaps lies her chief mistake, she does not follow the supernatural even as a possible refuge. The explanations whereby her multiplied. mysteries are ultimately dissipated, run on such severely natural lines a.s to recall the simplicity of Snug the joiner, and the reader is almost ashamed of his terrors when he is confronted with the dull mechanic who has simulated a lion so marvellously."1

I have quoted at length from the prefaces and works of the better known reactionaries to the matter-of-fact novel of Richardson, Fielding, Smollett, and Sterne to show that, even in the writings of the so-called Gothicists, the realistic tendency in the eighteenth-century novels never ceased.

The age of Pope and Johnson was too conservative to permit radical departures from the accepted canons. These canons were well intrenched in the life and thought of the times, and they were carefully garded by the regulars. The limited grasp of reactionary prose fiction could not suddenly and completely disrupt the tradition.

"The historians had made the baseless romance of the Middle Ages henceforth impossible, because incredible; its revival in Walpole's 'Castle of Otranto,' in Beckford's 'Vathek,' in Mrs. Radcliffe's 'Mysteries of Udolpho,' only make evident that the day of verity had sealed its doom."

When Johnson said that Richardson had "enlarged the knowledge of human nature," he was uttering a truth applicable in varying degrees to every eighteenth-century novelist. Fielding boldly asserted in his first chapter of

1. Walter Malelgh, "The English Novel," p. 228.

2. F. F. Stoddard, "Evolution of the Engllsh Novel," pp. 94-95. 
"Tom Jones" that the provision which he made here was no other than human nature. It is highly important to note, too, that to him, as to most novelists of his day and age, "'human nature' did not mean court nature with its conventions," as Professor Metcalf points out, "but rather the free man nearer to nature in the country than in the city."'

Fielding states very frankly why he prefers to choose his characters from the common walks of life: "What Mr. Pope says of women is very applicable to most in this (upper) station, who are, indeed, so entirely made up of form and affectation, that they have no character at all, at least none which appears. I will venture to say the highest life is much the dullest, and affords very little humor or entertainment. The various callings in lower spheres produce the great variety of humorous characters; whereas, except among the few who are engaged in the pursuit of ambition, and the fewer still who have a relish for pleasure, all is vanity and servile imitation. Dressing and cards, eating and drinking, bowing and courtesying, make up the business of their lives."3

Moreover, the "free man" here spoken of is an Englishman-a real flesh-and-blood person who lived and moved, loved and hated in the latter half of the eighteenth century. For this reason Leigh Hunt, in his "Novel Party," found Abraham Adams "better than all the characters in all the histories of the world, orthordox or not orthordox ... What a sound heart," he exclaimed, " and a fist to stand by it!"4 "Indeed, as a novel is substantially the embodiment of the remarks made by the ablest observers upon their contemporaries," says Leslie Stephen, "we may in some sense admit Fielding's claim to be a writer of history more faithful than the elaborate fictions generally known under that name."5

"And here I solemnly protest I have no intention to asperse or vilify anyone," says Fielding; "though every thing is copied from the book of nature, and scarce a

1. "Tom Jones," Bk. I, Ch. I.

2. J.C. Metcalf, 'Henry Fielding, Critic.' "Sewanee Review," XIX, p. 141.

3. "Tom Jones," Bk. Xív, Ch. 1.

5. Leslie Stephen, "History of English Thought in the Efghteenth Century," II. D. 379 . 
character or action produced which I have not taken from my own observations and experience. . . . " "

"I declare here, once and for all, $\dot{I}$ describe not men, but manners; not an individual, but a species. Perhaps it will be answered, are not the characters then taken from Life? To which I answer in the affirmative; nay I believe I might aver that I have writ little more than I have seen.'1

"These are pictures which must be, I believe, known: I declare they are taken from the life, and not intended to exceed it."'2

Sometimes Fielding says, unequivocally, in the midst of his story, that the persons either are known to him, or are intended as patterns for those whom he knows. He tells of Lady Bellaston, who, after pushing in her hoop sidewise before her, entered the room, "having first made a very low courtesy to Mrs. Fitzpatrick and as low a one to Mr. Jones." "We mention these minute matters," he says, "for the sake of some country ladies of our acquaintance, who think it contrary to the rules of modesty to bend their knees to a man."3

"Concerning Sophia Western," says Professor Cross, "Fielding left no doubt. This charming girl he meant as a portrait of Charlotte Cradock as she was when he first saw her in the freshness of youth and beauty at Salisburywhere he danced with her, addressed verses to her, and in the end fell upon his knees. Twice in 'Tom Jones' he made the identification complete. Sophia, he declared on her entrance into the novel, 4 was a copy from nature. . . And when the portrait was nearly finished; he told the reader that all the worth he had ascribed to Sophia 'once existed in my Charlotte." "5

"The total number of characters in the novel (Tom Jones'), which, counting those merely mentioned as well as those that actually appear, falls little short of two hundred. All that swarming host, I believe, came directly out of Fielding's memories. ... This conclusion receives support

1. Preface to "Joseph Andrews."

2. "Joseph Andrews," Bk. III, Ch. $i$.

5. "Tom Jones," Bk. XIII, Ch. Iv.

3. "mbld." BL. IV. Ch. 11 .

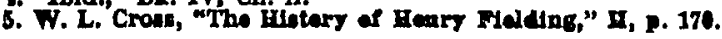


from the remark which Fielding made to Mrs. Hussey ... to whom he is reported to have said that he intended to introduce into 'Tom Jones' 'the characters of all his friends." "1

Fielding put his heart-felt invocation, which he addressed to Experience, in the thirteenth book of "Tom Jones." It dispels any lingering doubt there may be as to who his characters are, and where he found them:

"Lastly, come Experience, long conversant with the wise, the good, the learned, and the polite. Nor with them only, but with every kind of character from the minister at his levee to the bailiff in his spunginghouse; from the duchess at her drum to the landlady behind her bar. From these only can the manners of mankind be known; to which the recluse pedant, however great his parts or extensive his learning may be, hath ever been a stranger."2

In discoursing on the qualifications of an author who aspires to write such a history as is attempted in "Tom Jones," Fielding says:

"There is another sort of knowledge beyond the power of learning to bestow, and this is to be.had by conversation. So necessary is this to the understanding the character of men, that none are more ignorant of them than those learned pedants whose lives have been entirely consumed in colleges and among books; for however exquisitely human nature may have been described by the writers, the true practical system can be learnt only in the world." ... Of those taken from books, he declares such characters to be "only the faint copy of a copy, and can have neither the justness nor the spirit of the original."

He continues: "Now this conversation in our historian must be universal, that is, with all ranks and degrees of men; for the knowledge of what is called high life will not instruct him in low; nor, "e converso,' will his being acquainted with the inferior part of mankind teach him the manner of the superior. And though it may be thought that the knowledge of either may sufficiently enable him to describe at least

1. W. L. Cross, "The History of Henry Fleldiag," II, p. 170.

2. "Tom Jones," Bk. XIII, Ch. 1. 
that in which he has been conversant, yet he will even here fall greatly short of perfection; for the follies of either rank do in reality illustrate each other. For instance, the affectation of high life appears more glaring and ridiculous from the simplicity of the low; and again, the rudeness and barbarity of this latter strikes with much stronger ideas of absurdity, when contrasted with, and opposed to, the politeness which controls the former. Besides, to say the truth, the manners of our historian will be improved by both these conversations; for in one he will easily find examples of plainness, honesty, and sincerity; in the other of refinement, elegance, and a liberality of spirit; which last quality I myself have scarce ever seen in men of low birth and education." 1

Later he declares: "In short, imitation here will not do the business. The picture must be after Nature herself. A true knowledge of the world is gained only by conversation, and the manners of every rank must be seen in order to be known."2

Sterne seems to have held the same opinion: "Writing, when properly managed (as you may be sure I think mine is), is but a different name for conversation."3

"'To have invented that character (Amelia),' Thackeray wrote to Mrs. Brookfield, 'is not only a triumph of art, but it is a good action. They say that it was in his own home that Fielding knew and loved her: and from his own wife that he drew the most charming character in English Fiction! why fiction? why not history? I know Amelia just as well as Lady Mary Wortley Montagu.' And so we have Thackery exclaiming in his summary: 'What a wonderful art! what an admirable gift of nature was it by which the author of these tales was endowed, and which enabled him to fix our interest, to awaken our sympathy, to seize upon our credulity, so that we believe in his people-speculate gravely upon their faults or their excellences." "4

Fielding, as well as other novelists of the time, succeeded in the eighteenth century in getting his readers to deliberate upon the merits and demerits of the characters.

1. "Tom Jones," Bk, IX, Ch. 1 .

2. "Ibid," Bk. XIV, Ch.1.

9. "Tristram Shandy," II. Ch. ri,

4. Quoted in W. L. Cross's "History of Eenry Flelding," III, p. 218. 
Lady Luxborough wrote to the poet Shenstone from Barrells, March 23, 1749: "In the adventures that happen, I think he (Fielding) produces personages but too like those one meets with in the world; and even among those people to whom he gives good characters, he shows them in a concave glass which discovers blemishes that would not have appeared to the common eye."1 "But outsiders, with here and there an exception, did not quite understand Fielding's drift," says Professor Cross, for they "found men and women such as they had seen and known in real life; and they were nonplussed by Fielding's frank realism."2

Smollett defined the novel as "a large diffused picture, comprehending the characters of life."3 And in his preface to "Roderick Random" he declared, "I have not deviated from nature in the facts, which are all true in the main."

Sterne discovered that "Human-nature is the same in all professions";4 and later, when reflecting upon Corporal Trim, said: "Tread lightly on his ashes, ye men of genius,for he was your kinsman."

"Fielding, Smollett, and Sterne," says Professor Cross, "all had the reputation in their time of taking their leading characters from actual experience."5

Horace Walpole, the professed reactionary toward what he considered the tendency to dam up the sources of fancy because of a too strict adherence to common life, did not care to risk the "horse-laugh" of his readers; and so an explanation in the form of an apology was deemed the part of wisdom: "With regard to the deportment of the domestics, . . . I will beg leave to add a few words. The simplicity of their behaviour, almost tending to excite smiles, which at first seems not consonant to the serious cast of the work, appeared to me not only not improper, but was marked designedly in that manner. My rule was nature."6

Richardson defended his delineation of Lovelace in a letter to Aaron Hill January 26, 1747: "I must own that I am a

1. Quoted in W. L. Cross's "History of Henry Flelding," II, pp. 127-128.

2. "Ibld.". pp. 126-127.

3. Dedicatton of "Ferdinand Court Fathom."

4. "Tristram Shandy," II, Ch, xvili

5. W. L. Cross, "Development of the English Novel," p. 72.

6. "The Castle of Otranto." Preface to the Second Edition. 
good deal warped by the Character of a Gentleman I had in my eye, when I drew both him, and Mr. B. in "Pamela."1 He declared in his preface to "Pamela," that the story had its foundation both in truth and in nature. As to the truth, genuineness, and reality of the foundation of this first English novel, we have the author's own statement in a letter to Aaron Hill.

Thus, from Richardson onward, the new novel owed its origin and subsequent development largely to the reaction of English thought against all that was manifestly incredible. Practically all that was foreign and extraneous was anathematized and tabooed. The new novel was leading back to a genuine respect for truth in art; and it was rapidly discovering its fit form and subject-matter in the reasonable and the matter-of-fact incidents of everyday, contemporary English life. The characters that appeared were generally men and women whom the novelist had known.

"There came a day when the tale of all these external, far-off, glories of unrealities passed away, and in its place came the simple story of a humble life, in scenes real at hand; the story of the emotion of a simple, homely, struggling soul. ... In the middle years of the seventeenth century there came such a day. When that day came, it was the birthday of the English novel."2

1. Barbauld, "Correspondence of Richardson."

2. F. H. Stoddard, "Evolution of the English" Novel," pp. 41-6. 


\section{CHAPTER III}

\section{THE AVOWED PURPOSES OF THE NOVEL}

The rise of the novel in $\mathbf{1 7 4 0}$ marks the end of prose fiction designed solely for amusement and entertainment. The critical nature of the new type is nearly always apparent from this date, and usually there is a well defined purpose clearly expressed in the author's preface. "Never was there a body of writers," says Professor Raleigh, referring to the leading novelists, "of whom it might more truly be said that their work is a criticism of life." And he suggests the purpose and scope of this criticism when he declares that the theme of the eighteenth-century novel is the history of persons, regarded as moral beings, and treated in relation to each other and to society. ${ }^{1}$ The second and third quarters of the eighteenth century were years particularly watchful and critical in all matters affecting the religious, moral, social, and political conditions of the times.

The influence of the great religious revival of Wesley and Whitefield had reached the masses in whose interest mainly it was carried on, and it had already accomplished much by 1740 . In the spiritual renaissance of the first half of the eighteenth century, were laid the foundation-stones of liberalism and reform. It was inevitable that fiction should align itself with the new forces and point out the follies of everyday life.

The main purpose of the old romance was entertainment and amusement; but the pendulum swung to the opposite extreme when Richardson's first novel was given to the public. After this event, all of the great eighteenthcentury novelists, under the disguise of amusement, boldly and somewhat ostentatiously announce in their preface that their object is "to promote the cause of religion and virtue." The common practice was to select men and women

1. Walter Ralelgh, "The English Novel," p. 211. 
from real life "for example sake"; ${ }^{1}$ and thus, combined with the power of precept, they instruct the reader while showing vice and virtue in their true light.

In 1756, abridged editions of "Pamela," "Clarissa Harlowe," and "Sir Charles Grandison" were prepared for the public under the caption, "The Paths of Virtue delineated; or, the History in Miniature of the Celebrated Pamela, Clarissa Harlowe, and Sir Charles Grandison, familiarized and adapted to the Capacities of Youth." A review of this work appears in the "Critical Review" for the month of May, 1756 , in which is reflected the response by the reading public to the author's gift as a preacher: "The character of the (original) books, with an abridgement of which we are here presented, is already so well known, that it would be needless for us to say anything upon that head, nor is it properly our province. The author must certainly have secured them the esteem of every friend to virtue and religion; and we are glad to find them now reduced to such a size as may fit them for every hand; for certainly few books of entertainment are so well adapted to the instruction of youth."2

When the future author of "Pamela" and "Clarissa" was telling stories to his school-fellows, "some of which," he says, "I told them from my reading, as true, ... and all of my stories carried with them, I am bold to say, an useful moral," 3 he was being unconsciously prepared for the crowning glory of his life, which was to come many years later. There can be no doubt that by 1740 the cause of religion and virtue was very close to the heart of the London printer. To his friend Aaron Hill's letter, inquiring as to the origin of "Pamela," he replied: "I thought the story, if written in an easy and natural manner, suitable to the simplicity of it, might possibly introduce a new species of writing, that might possibly turn people into a course of reading different from the pomp and parade of romance writing, and dismissing the improbable and marvellous,

1. Miss Howe to Clarissa: "Every eyc, in short, is upon you with the ex-

pectation of an exnmple." "Clarissa Harlowe," 1, Letter 1.

2. "Critical Review," May, 1756, p. 315.

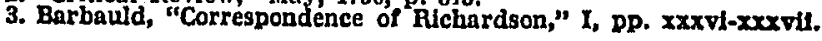


with which novels generally abound, might tend to promote the cause of religion and virtue."1

Richardson tells us that several admirers submitted prefaces designed for publication with "Pamela," but that he rejected them all because he preferred to use his own words. He thus explains and defends the purpose of the first English novel:

"If to Divert and Entertain, and at the same time to Instruct and Improve the Minds of the Youth of both Sexes:

"If to inculcate Religion and Morality in so easy and agreeable a manner, as shall render them equally delightful and profitable:

"If to set forth in most exemplary Lights, the Parental, the Filial, and the Social Duties:

"If to paint Vice in its proper Colours, to make it deservedly Odious; and to set Virtue in its own amiable Light, to make it look Lovely:"

Five more "If's" equally significant to the author follow, and he concludes:

"If these be laudable or worthy of Recommendation, the Editor of the following Letters, which have their Foundation both in Truth and Nature, ventures to assert, that all these Ends are obtained here, together."

In his preface to the second part of "Pamela," the anthor indulges the hope that his readers will find these letters "equally written to Nature; . . . and rules, equally new and practicable, inculcated, throughout the whole, for the general conduct of life."'

Concerning "Clarissa," he says: "This work being addressed to the public as a history of life and manners, those parts of it which are proposed to carry with them the force of example, ought to be as unobjectionable as is consistent with the design of the whole, and with human nature."3

A young lady, who is "endowed with the noblest principles of virtue and religion," and who "is proposed as an exemplar to her sex," "is seen involved in such a variety of deep distresses, as lead her to an untimely death; affording a warning to parents against forcing the inclinations of

1. Barbauld, "Correspondence of Richardson," pp. Ixxlil-lxxiv.

3. The Preface, and the Postscript to "Clarissa Harlowe." 
their children in the most important article of their lives; and to children, against hoping too far from the fairest assurance of a man void of principles."1

"Sir Charles Grandison is, therefore, in the general tenor of his principles and conduct, ... proposed for an example; and, in offering him as much, were his character still more perfect than it is presumed to be, the Editor is supported by an eminent divine of our country. ${ }^{2}$

"There is no manner of inconvenience in having a pattern propounded to us of so great perfection, as is above our reach to attain. The way to excel in any kind, is 'optima quaeque ad imitandum proponere'; to propose the brightest and most perfect examples to our imitation. . .."

The letters written by Clarissa's 'cruel destroyer,' 'it is hoped, afford many useful lessons to the gay part of mankind against the misuse of wit and youth, of rank and fortune, and of every outward accomplishment, which turns them into a curse to the miserable possessor, as well as to all around him."3

"It will be seen, by this time, that the author had a great end in view. He had lived to see skepticism and infidelity openly avowed, and even endeavored to be propagated from the press; the great doctrines of the Gospel brought into question; those of self-denial and mortification blotted out of the catalogue of Christian virtues; and a taste even to wantonness for out-door pleasure and luxury, to the general exclusion of domestic as well as public virtue, industriously promoted among all ranks and degrees of people. In this general depravity, when even the pulpit had lost great part of its weight, and the clergy are considered as a body of interested men, the author thought he should be able to answer it to his own heart, be the success what it would, if he threw in his mite towards introducing a reformation so much wanted: and he imagined, that if in an age given up to diversion and entertainment, he could steal in, as may be said, and investigate the great

1. Preface to "Sir Charles Grandison."

2. Concluding Note to "Sir Charles Grandison."

Richardson held that all characters designed to be successful should be patterns nearly perfect in virtue and honor. In the Concluding Note he asks: "Is not vice crowned with success, triumphant, and rewarded and, perhaps set off with wit and spirit, a dangerous representation?" of perhaps, set off with wit and spirit, a his rival, Flelding, ton.

3. Preface to "Sir Charles Grandison." 
doctrines of Christianity under the fashionable disguise of amusement; he should be most likely to serve his purpose...."1

In the preface to "Clarissa," the author gives some things that are "more particularly aimed at": "To warn the inconsiderate and thoughtless of one sex, against the base arts and designs of specious contrivers of the other-to caution parents against the undue exercise of their natural authority over their children in the great article of marriage - to warn children against preferring a man of pleasure to a man of probity upon the dangerous but too commonly received notion, that a reformed rake makes a good husband--but above all, to investigate the highest and most important doctrines not only of morality, but of Christianity, by showing them thrown into action in the conduct of the worthy characters; ... .

Richardson was perhaps more severely criticised in his day for his open attack against the thory of poetical justice and the universally accepted notion of honor involved in the practice of dwelling, than he was for any of the other reforms he championed. In defense of Sir Charles's courage, honor, and integrity of character, which were at stake because he refused what were called "polite invitations to murder," the author maintained that "the true bravery is to adhere to all duties under all disadvantages; and, that refusing a duel is a duty to ourselves, our fellow-creatures, and our maker." 3

In a letter dated 7th November, 1748, Richardson wrote: "These (advance copies) will show you, sir, that I intend more than a Novel of Romance by this Piece; and that it is of the tragic kind: In short, that I thought my principal Character could not be rewarded by any Happiness short of the Heavenly. But how have I suffered by this from the Cavils of some, from the Prayers of others, from the entreaties of many more, to make what is called a Happy ending!-Mr. Lyttelton, the late Mr. Thompson, Mr. Cibber, and Mr. Fielding have been among these."

"If the temporary suffering of the virtuous and good can be accounted for and justified on Pagan principles (which

1. Postscript to "Clarissa Harlowe."

2. Preface to "Clarissa Farlowe."

3. Concluding Note to "Sir Charles Grandison." 
it can be), many more and infinitely stronger reasons will occur to a Christian reader in behalf of what are called unhappy catastrophes, from the consideration of the doctrine of future rewards; which is everywhere strongly enforced in the History of Clarissa." 1 And on another page of the same, he attempts to justify his attitude: "The Author of the History (or rather Dramatic Narrative) of Clarissa is therefore well justified by the Christian system in deferring to extricate suffering virtue to the time in which it will meet with the completion of its reward." For all those who entered into the sufferings of the unfortunate heroine, the author held out these condolences: "The heroine, however, as a truly Christian heroine, proves superior to her trials; and her hear' always excellent, refined and exalted by every one of them, rejoices in the approach of a happy eternity."2 He maintains that Heaven only could reward a young lady of such Christian virtue and honor, and appends a footnote in which he reminds the reader "that so early in the work as Vol. II. Letter XL., the dispensations of Providence are justified by herself." He continues: "And thus she ends her reflections-'I shall not live always-may my closing scene be happy!' he concludes: "She had her wish. It was "Happy." "3

Miss Thompson thinks that Richardson never quite freed himself from the puritanical prejudice against fiction; and says that he would have had his books classed, not with "Robinson Crusoe," or "Oroonoko," or "Moll Flanders," but with works of devotion, such as Taylor's "Holy Living and Dying," the "Practice of Piety," and Nelson's "Fasts and Festivals;" "not as being unworthy of such company, but that they may have a chance of being dipt into thirty years hence; . . . they will not be found unworthy of such a chance, since they appear in the humble guise of a novel only by way of accomodation to the manners and taste of an age overwhelmed with luxury, and abandoned to sound and senselessness.' Such being his view, she adds, "It is not surprising that his amiable characters are at so

1. Pnstscript to "Clarissa Harlowe."

2. Preface to "Sir Charles Grandison."

3. Postscript to "Clarissa Harlowe." 
much pains to rebuke offenders and formulate moral laws for the benefit of all their acquaintance, or even his bad ones, Lovelace included, should indulge in a vast amount of serious reflection." 1 There can be no doubt that the obscure printer of London was sincere in his efforts at reform by means of fiction.

But Richardson found it very difficult to understand how anyone could possibly put Fielding in a class with reformers. The "low" morality of "The Foundling" had, he thought, an "evil tendency." Of course he professes never to have read these books for fear of contaminating his mind; but always to have depended upon the judgment of his friends, which judgment he severely reprimanded if it tended to praise his rival's work. Aaron Hill's daughters, Minerva and Astraea, were asked to read "Tom Jones" and give their opinjon of it. When they were little girls, they had wept over "Pamela" while reading it, and naturally he expected a scathing criticism of "Tom Jones." But to his amasement and chagrin these "two wise heads" discovered "much masqu'd merit, both of head and heart" in the work. "The whole piece," they wrote, "consists of an inventive Race of Disappointments and Recoveries. . . .Its Events reward Sincerity, and punish and expose Hypocrisy; shew Pity and Benevolence in amiable Lights, and Avarice and Brutality in very despicable ones. In every Part it has Humanity for its Intentions. ..."2

The jealous author of "Pamela" must have felt indignant at this favorable comment, for just one week later he replied: "I must confess, that I have been prejudiced by the Opinion of Several judicious Friends against the truly coarse-titled 'Tom-Jones'; and so have been discouraged from reading it. ${ }^{3}$ I was told, that it was a rambling Collection of Waking Dreams, in which Probability was not observed: And that it had a very bad Tendency. And I had

1. Clara L. Thompson, "Samuel Richardson," pp. 255-256.

2. See W. I. Cross's, "The History of Henry Fleiding," Ii, p. 146.

. Fielding undoubtedly had this type of critic in mind when he wrote: "But without ascertaining all the proper qualifications of a critic.... I think I may very boldly object to the censures of any one passed upon works which he hath not himself read. Such censurers as these, whether they speak from their own guess or suspicion, or from the report and opinton of others, may properly be said to slander the reputation of the book they condemn."-"Tom Jones," Bk. XI, Ch. $i$ 
Reason to think that the Author intended for his Second View (His first to fill his Pocket, by accommodating it to the reigning Taste) in writing it, to whiten a vicious character, and to make Morality bend to his Practice. What reason had he to make his Tom illegitimate, in an Age where Keeping is become a fashion? Why did he make him a common-What shall I call it? And a Kept Fellow, the Lowest of Fellows, yet in love with a Young Creature who was trapping after him, a Fugitive from her Father's House? - Why did he draw his heroine so fond, so foolish, and so insipid? Indeed he has one Excuse-He knows not how to draw a delicate Woman-He has not been accustomed to such Company,-And is too prescribing, too impetuous, too immoral, I will venture to say, to take any other Byass than that a perverse and crooked Nature has given him; or Evil Habits, at least, have confirm'd in him. Do men expect Grapes of Thorns, or Figs of Thistles? But, perhaps, I think the worse of the Piece because I know the writer, and dislike his Principles both Public and Private, tho' I wish well to the Man, and Love Four worthy Sisters of his, with whom I am well acquainted. And indeed should admire him should he make the Use of his talents which I wish him to make. For the Veign of Humor, and Ridicule, which he is master of, might, if properly turned, do great Service to the Cause of Virtue."1

Such was the ill-advised judgment of this biased critic who had the distinction of being the first, and perhaps the only great novelist at this time, the author of "Tom Jones" excepted. Barring enmity against Fielding, owing to his "ungenerous engraftment," and jealousy of him, owing to the increasing popularity of his works, it is very probable that Richardson was sincere in his judgment; for the two differ fundamentally in their attitude towards morality.

"Where Richardson saw only perfection," says Professor Cross, "he (Fielding) discovered flaws; where Richardson saw unrelieved vice, he saw streaks of something that resembled goodness, such as the transcient compunction of Jonathan Wild for the pain inflicted upon his victims. Likewise, the four lewd women in 'Tom Jones'-Molly Sea-

1. See W. X. Cross's, "The History of Eenry Flelding," II, p. 147. 
grim, Mrs. Walters, Mrs. Fitzpatrick, and Lady Bellaston, each carefully differentiated from the others in accordance with the grade of society to which she belonged-are given in union with their predominant weakness those admirable qualities which they possessed in real life."1

"Pamela" and "Clarissa Harlowe" "merely evoked the reply from Fielding," he says, "that Mr. Richardson could hardly hope to reform the age by imposing upon it manners worse than those existing anywhere in town or country." Consequently, "he wrote a novel on the lines of 'Pamela,' descriptive of life as he had seen it in the country, true in all exterior details as well as in sentiment and motives; true also to the primal emotions which, 'mutatis mutandis,' have always geverned the conduct of men and women."2 In other words, Fielding wrote "with his eye on life"; Richardson wrote, as he himself tells us, with "his eye upon the ladies"-and of course he was coached by them. He records of himself that when he was still a small boy he had two peculiarities, one of which was, that he loved the society of women best. As to his inclinations later in life, he declares: "My acquaintance lies chiefly among the ladies; I care not who knows it." It is evident that he had seen too little of real life to know what it actually was'. "Richardson's knowledge," says Mrs. Oliphant, "was only of good sort of people, and secondary literateurs, andwomen, who are not the world, as everybody knows."3

In collaboration with the ladies who surrounded Richardson in the little room in which he wrote, sentimental idealism, or life as they imagined it ought to be, was the inevitable result; but when Fielding entered upon the great epic of the road, he found it "very difficult to pursue a series of human actions, and keep clear from vice."4 But even so; Mrs. Oliphant maintained openly that Fielding's "wickednesses are not wicked, but merc accidents-warmth of blood and rapidity of movement carrying him away. And then his knowledge of the world."5

1. See W. L. Cross's, "The History of Henry Fielding," III, p. 275.

2. "Ibld.

. 'Historical Sketches in the Relgn of George II.' "Blackwood's," March,

1869 , p. 254 .

Preface to "Joseph Andrews."

"Historical Sketches in the Reign of George 11." "Blackwood's," March, 1860, p. 254. 
Certainly no one, not even Richardson, has a right to judge a book immoral until he knows the author's intentions. As to "Joseph Andrews" and "Tom Jones," the author is very frank and explicit in disclosing his artistic aims and moral purposes. He justifies them in the eighteenth century, and is even now in the twentieth century fully capable of justifying his own motives.

"Truth," says Professor Perry, "shall be the keynote of his (the novelist's) art, and the truth that he reveals shall be seen in us as beauty." Mr. Fielding was certainly seeking the truth concerning human nature, if we may judge from the chapter beginning the thirteenth book of "Tom Jones," in which he invokes to his aid, "Experience, long conversant with the wise, the good, the learned, and the polite. Nor with them only, but with every kind of character, from the minister at his levee to the bailiff in his spunging house; from the duchess at her drum to the landlady behind her bar. From thee only, can the manners of mankind be known; to which the recluse pedant, however great his parts or extensive his learning may be, hath ever been a stranger."2 The fruit of Fielding's wide observation upon human nature is seen in Tom Jones whom his creator would have us accept as a very fine type of person-a charming figure: one adorned with youth, health, strength, freshness, spirit, and good nature. ${ }^{3}$

"The following book," Fielding declared of 'Amelia," "is sincerely designed to promote the cause of virtue, and to expose some of the most glaring evils, as well public as private, which at present infest the country....."4 And he adds presently: "To retrieve the ill consequences of a foolish conduct, and by struggling manfully with distress to subdue it, is one of the noblest efforts of wisdom and virtue."55

"I declare that to recommend goodness and innocence hath been my sincere endeavor in this history. This honest purpose you have been pleased to think I have attained: and to say the truth, it is likeliest to be attained in books of this kind; for an example is a kind

1. Bliss Perry, "A Study of Prose Flction," p. 257.

2. "Tom Jones," Bk. XIII, Ch. 1.

3. "Ibid.." Bk. IX, Ch. il.

4. Dedicatton of "Amelia."

5. "Amella," Ch. 1 . 
of picture, in which virtue becomes, as it were, an object of sight and strikes us with an idea of that loveliness, which Plato asserts there is in her naked charms."1

"The author everywhere teaches this moral, that the greatest and truest happiness which this world affords, is to be found only in the possession of goodness and virtue; a doctrine, which as it is undoubtedly true, so hath it so noble and practical a tendency, that it can never be too often or too strongly inculcated on the minds of men."2

"It is a trite but true observation that examples work better on the mind than precepts: and if this be just in what is odious and blamable, it is more strongly so in what is amiable and praiseworthy. ... . A good man therefore is a standing lesson to all his acquaintances. .." "3

In a letter to Mr. Allworthy, Square, the philosopher, had this to say concerning Tom Jones: "Believe me, my friend, this young man hath the noblest generosity of heart, the most perfect capacity for friendship, the highest integrity, and indeed, every virtue which can enoble a man.",

In "Jonathan Wild," the author aimed to present the history of a character, neither totally good nor bad, to insure "the great perfection called uniformity of character." "We would not, therefore, be understood to affect giving the reader a perfect or consummate pattern of human excellence, but rather, by faithfully recording some little imperfections which shadow over the lustre of those great qualities which we shall here record, to teach the lesson. .."5

"I believe it is much easier to make good men wise, than to make bad men good. ... I I have employed all the wit and humor of which I am master in the following history. ... to taugh mankind out of their favorite follies and vices."

Fielding was always careful to disclaim any intention to vilify particular persons; and so, referring to the lawyer in "Joseph Andrews," he states very frankly that he does not intend to expose one pitiful wretch to the small and con-

1. Dedication of "Tom Jones."

2. Introduction to "A Journey from This World to the Next."

3. Preface to "Joseph Andrews."

4. "Tom Jones," BK. XVIII, Ch. Iv

5. "Jonathan Wild," Bk, I, Ch. 
temptible circle of his acquaintance, but that he does intend to hold the glass to thousands in their closets, that they may contemplate their deformity, and endeavor to reduce it."1

"By examining carefully the several gradations which conduce to bring every model to perfection, we learn truly to know that science in which the model is formed: as histories of this kind, therefore, may properly be called models of 'Human Life,' so, by observing minutely the several incidents which tend to the catastrophe or completion of the whole, and the minute causes whence those incidents are produced, we shall best be instructed in the most useful of all arts, which I call the "Art of Life." "2

In the introductory chapter to the last book of "Tom Jones," the author makes this leave-taking confession to his readers: "And now, my friends, I take this opportunity. . . of heartily wishing thee well. If I have been an entertaining companion to thee, I promise thee it is what I have desired. ..."”3

The last book that Fielding wrote for publication was "The Voyage to Lisbon." In the concluding paragraph of his preface, the dying man dispels from the mind of his readers any lingering doubt there may be as to his own aims and sincere motives:

"One hint, however, I must give the kind reader: which is, that if he should be able to find no sort of amusement in the book, he will be pleased to remember the public utility which will arise from it. If entertainment, as Mr. Richardson observes, is but a secondary consideration in a romance; with which $\mathrm{Mr}$. Addison, I think, aggrees, . . . . if this, I say, be true of a mere work of invention, surely it may well be so considered in a work founded, like this, on truth; and where the political reflections form so distinguishing a part.

"But perhaps I may hear, from some critic of the most saturnine complexion, that my vanity must have made a horrid dupe of my judgment, if it hath flattered me with an expectation of having anything here

1. "Joseph Andrews," Bls. III, Ch. 1.

2. "Amelia," BK, Bl, XVir, Ch. 1. 
seen in a grave light, or of conveying any useful instruction to the public, or to the guardians. I answer with the great man whom I just now quoted, that my purpose is to convey instruction in the vehicle of entertainment. .."1

Fielding was certainly a conscious reformer. As playwright, as justice, as novelist, his wit and humor were repeatedly directed against the corruption and vice of the day. But (and this is greatly to the artist's credit) Fielding seems never to have been an insistent reformer. He earnestly desired to expose sham and hypocrisy in politics, in society, and in religion; consequently he marshalled all the wit and humor at his command to this end, but he formulated no system or code of morality as did Richardson.

Professor Phelps pronounces Tobias Smollett a "naturalist," 2 which pronouncement is certainly not far from the truth. The genuine delight that he manifests in describing many of the indecent facts of life, with which his works abound, is, to say the least, closely akin to the coarser physical passions. But whether or not Smollett's plea in his preface is hypocritical, as Professor Raleigh maintains, ${ }^{3}$ does not concern us here. Granted, however, that it is true, the accusation tends to confirm one of the contentions of this thesis, namely that public sentiment was rapidly crystallizing on the matter of reform; and, therefore, the novelist, even though sometimes contrary to his personal inclinations, was forced to design his book to satify his reader's taste for moralization. Richardson's temperament made it quite easy for him to comply with the pervailing sentiment; but Smollett's disposition was a very different one. His training and experience very probably rendered him impotent, within the body of his work, to yield to the prevalent taste. He obviated this difficulty by pretending in his preface to have so yielded. He was in doubt as to how his book would be received, for he states frankly that his "fate with the public is uncertain." For the present, however, we are interested only in what he himself declared his aim and purpose to be.

1. Preface to "The Voyage to Lisbon."

2. W. L. Phelps, "The Advance of the English Novel," p. 65.

3. Walter Raleigh, "The English Novel," pp. 187-188." 
"Let me not, therefore, be condemned for having chosen my principal character from the purlieus of treachery and fraud," he begs, "when I declare my purpose is to set him up as a beacon for the benefit of the unexperienced and unwary. ..."

"If I have not succeeded in my endeavours to unfold the mysteries of fraud, to instruct the ignorant and entertain the vacant; if I have failed in my attempts to subject folly to ridicule, and vice to indignation; to rouse the spirit of mirth, wake the soul of compassion, and touch the secret springs that move the heart; I have, at least, adorned virtue with honor and applause, branded iniquity with reproach and shame, and carefully avoided every hint or expression which could give umbrage to the most delicate reader. .."1

A "principal personage," he maintained, was always necessary in the novel "to attract the attention." As to how successful the author's "beacon" was in attracting attention, we have the judgment and testimony of one, Dr. Robert Anderson, a Scottish physician, who brought out in 1800 an edition of Smollett's works with a memoir: "On the great question at issue his (Anderson's) conclusion was that 'after perusing the wire-drawn history of 'Clarissa,' and the diffuse narrative of 'Tom Jones,' we never quit them with so much reluctance as we feel in closing the pages of Smollett, who, with less regularity of fable, and without introducing so many observations of a moral tendency, or so much of what may be called fine writing, possesses, in an eminent degree, the art of rousing the feelings and fixing the attention of his readers." "2

Smollett frankly admits in his preface that the principal character is tainted with vice and fraud; but he also tries hard to convince the reader that such a one is set up for a beacon. Richardson intended that his characters should be "fit to model adolescence by." Smollett intended, according to his own statement, that his should be a warning to adolescence. He might have reasoned, "My purpose is the same as Richardson's; only the means, in this one respect, differs." 
It is doubtful if Laurence Sterne had, or, at least, professed to have had a distinctly moral or ethical purpose in writing fiction. Yet the following sentences perhaps imply much more than they say, and are, therefore, not without significance here. In his dedication of "Tristram Shandy" to Mr. Pitt, he declares: "I am firmly persuaded, that every time a man smiles-but much more so when he laughs,it adds something to this Fragment of Life." And he continues: "I humbly beg, Sir, that you will honor this book by taking it-(not under your protection,-it must protect itself, but)-into the country with you; where, if I am ever told it has made you smile, or can conceive it has beguiled you of one moment's pain-I shall think myself as happy as a Minister of Siate..."1

Within the book itself Sterne gives us his characterization of Shandeism, and tells us what its effect on human nature may be: "True Shandeism, think what you will against it, opens the heart and lungs; and, like all those affections which partake of its nature, it forces the blood and other vital fluids of the body to run freely through their channels, and makes the wheels of life run long and cheerfully round."'2

Johnson leaves no doubt as to the ethical and moral purpose of his "Rasselas." Turn at random to any page, and a text suitable for a sermon is there. In the opening lines, the author announces his purpose to write a disquisition on The Vanity of Human Wishes: "Ye who listen with credulity to the whispers of fancy, and pursue with eagerness the phantoms of hope; who expect that age will perform the promises of youth, and that the deficiencies of the present day will be supplied by the morrow, attend to the history of Rasselas, Prince of Abyssinia."3

Johnson published his opinions at length in the "Rambler." Here he expressed not only his own settled convictions, but summarized in a clear and forceful manner several phases of eighteenth-century theory of novel writing.

"The works of fiction, with which the present generation seems more particularly delighted, are such as

1. Dedication of "Tristram Shandy."

2. "Tristram Shandy," IV, Ch. xxxi1.

3. "Rasselas," Ch. 1. 
exhibit life in the true state, diversified by accidents that daily happen in the world, and influenced by passions and qualities which are really to be found in conversing with mankind.

"This kind of writing may be termed not improperly the comedy of romance, and is to be conducted nearly by the rules of comic poetry. Its province is to bring about natural events by easy means, and to keep curiosity without the help of wonder: it is therefore precluded from the machines and expedients of the heroick romance, and can neither employ giants to snatch away a lady from the nuptial rites, nor knights to bring her back from captivity; it can neither bewilder its personages in deserts, nor lodge them in imaginary castles."

"The task of our present writers is very different (from that of the authors of the old romance); it requires, together with that learning which is to be gained from books, that experience which can never be attained by solitary diligence, but must arise from general converse and accurate observation of the living world. Their performances have, as Horace expresses it, 'plus oneris quantum veniae minus,' little indulgence, and therefore more difficult. They are engaged in portraits of which every one knows the original, and can detect any deviation from exactness of resemblance. Other writings are safe, except from the malice of learning, but these are in danger from every common reader: as the slipper ill executed was censured by a shoemaker who happened to stop in his way at the Venus of Apelles.

"But the fear of not being approved as just copiers of human manners, is not the most important concern that an author of this sort ought to have before him. These books are written chiefly to the young, the ignorant, and the idle, to whom they serve as lectures of conduct, and introductions into life. They are the entertainment of minds unfurnished with ideas, and therefore easily suceptible of impressions; not fixed by principles, and therefore easily following the current of fancy; not informed by experience, and consequently open to every false suggestion and partial account.

"That the highest degree of reverence should be paid to youth, and that nothing indecent should be suffered to approach their eyes or ears, are precepts extorted by sense and virtue from an ancient writer, by 
no means eminent for chastity of thought. The same kind, though not the same degree of caution, is required in every thing which is laid before them, to secure them from unjust prejudices, perverse opinions, and incongruous combinations of images.

"In the romances formerly written, every transaction and sentiment was so remote from all that passes among men, that the reader was in very little danger of making any applications to himself; the virtues and crimes were equally beyond his sphere of activity; and he amuses himself with heroes and with traitors, deliverers and persecutors, and with beings of another species, whose actions are regulated upon motives of their own, and who had neither faults nor excellencies in common with himself.

"But when an adventurer is levelled with the rest of the world, and acts in such scenes of the universal drama as may be the lot of any other man; young spectators fix their eyes upon him with closer attention, and hope, by observing his behaviour and success, to regulate their own practices, when they shall be engaged in the like part.

"For this reason these familiar histories may perhaps be made of greater use than the solemnities of professed morality, and convey the knowledge of vice and virtue with more efficacy than axioms and definitions. But if the power of example is so great as to take possession of the memory by a kind of violence, and produce effects almost without the intervention of the will, care ought to be taken, that, when the choice is unrestrained, the best examples only should be exhibited; and that which is likely to operate so strongly, should not be mischevious or uncertain in its effects.

"The chief advantage which these fictions have over real life is, that their authors are at liberty, though not to invent, yet to select objects, and to cull from the mass of mankind, those individuals upon which the attention ought most to be employed: as a diamond, though it cannot be made, may be polished by art, and placed in such a situation, as to display that lustre which before was buried among common stones.

"It is justly considered as the greatest excellency of art, to imitate nature; but it is necessary to distinguish those parts of nature, which are most proper for imitation: greater care is still required in representing 
life, which is so often discoloured by passion or deformed by wickedness. If the world be promiscuously described, I cannot see of what use it can be to read the account: or why it may not be as safe to turn the eye immediately upon mankind as upon a mirrour which shows all that presents itself without discrimination.

"It is therefore not a sufficient vindication of a character, that it is drawn as it appears; for many characters ought never to be drawn; nor a narrative, that the train of events is agreeable to observation and experience; for that observation which is called knowledge of the world, will be found more frequently to make men cunning than good. The purpose of these writings is surely not only to show mankind, but to provide that they may be seen hereafter with less hazard; to teach the means of avoiding the snares which are laid by Treachery for Innocence, without infusing any wish for the superiority with which the betrayer flatters his vanity; to give the power of counteracting fraud, without the temptation to practice it; to initiate youth by mock encounters in the art of necessary defence, and to increase prudence without impairing virtue."

"In narratives where historical veracity has no place, I cannot discover why there should not be exhibited the most perfect idea of virtue not angelical, nor above probability, for what we cannot credit, we shall never imitate, but the highest and purest that humanity can reach, which, exercised in such trials as the various revolutions of things shall bring upon it, may, by conquering some calamities, and enduring others, teach us what we may hope, and what we can perform. Vice, for vice is necessary to be shown, should always disgust; nor should the graces of gayety, or the dignity of courage, be so united with it, as to reconcile it to the mind. Wherever it appears, it should raise hatred by the malignity of its practices, and contempt by the meanness of its stratagems; for while it is supported by either parts or spirit, it will be seldom heartily abhorred. The Roman tyrant was content to be hated, if he was but feared; and there are thousands of the readers or romances willing to be thought wicked, if they may be allowed to be wits. It is therefore to be steadily inculcated, that virtue is the highest proof of understanding, and the only solid basis of greatness; and that vice is the natural consequence of narrow 
thoughts; that it begins in mistake, and ends in ignominy."1

Horace Walpole caled "Clarissa Harlowe" and "Sir Charles Grandison" "tedious lamentations," and "romances as they would be spiritualized by a Methodist preacher." In "Rasselas" this moralizing tendency has gone even farther. "The novel of Richardson," says Professor Cross, "has thus been turned to the purpose of an excellent funeral sermon."2

Sterne's indirect influence upon the masses as liberator of the novel was doubtless far more potent, in the long run, than any hidden intention or motive to reform society could have been. In the matter of social reform, his works show very little, if any, indication of desire for change. The real purpose this inovator seems to have had in using the novel was a personal one, namely that he might have free utterance for his own peculiar way of viewing life; and that while giving his own views, he might cut such a caper before the literary public as to encourage, and possibly to excite others to disregard the "rules and compasses" of NenClassicism. With the small critics of his day-those "befetched with the bobs and trinkets of criticism"-he had no patience. It was largely because of such critics that there was danger, by 1760 , of the novel becoming little more than a photographic reproduction of the social conditions of the times. Sterne calmly and quitely determined it should not become such; and hence he defiantly threw himself directly across the traditions. In thus asserting his own liberty, he was making liberty reasonably safe for all who would follow.

"Sterne's well-known outburst as to criticims," says Professor Saintsbury, "is far too famous a thing to be passed over with the mere allusion given to it. . . Nay, it may be said at once, from its fame and from its forcible expression, to have had, and even in a sense still to have, no small place among the Dissolvents of Judgment by Rule." 3 The fact that his criticism had great liberalizing influence upon the

1. The "Rambler," No. IV

2. W. L. Cross, "Development of the English Novel," p. 78.

3. George Salntsbury, "A History of Critcism," III, p. 86 . 
theory of novel writing in Sterne's day, is reason for its reappearance here at length:

"Now don't let us give ourselves a parcel of airs, and pretend that the oaths we make free with in this land of liberty of ours are our own; and, because we have the spirit to swear them,-imagine that we have had the wit to invent them too.

"I'll undertake this moment to prove it to any man in the world, except to a connoisseur in swearing,-as I would do to a connoisseur in painting, \&c., \&c., the whole set of 'em are so hung round and befetish'd with the bobs and trinkets of criticism,--or, to drop my metaphor, which bye the bye is a pity,-for I have fetched it as far as from the coast of Guinea,-their heads, Sir, are stuck so full of rules and compasses, and have that eternal propensity to apply them upon all occasions, that a work of genius had better go to the Devil at once, than to stand to be prick'd and tortur'd to death by 'em.

"-And how did Garrick speak the soliloquy last night?-Oh, against all rule my Lord-most ungramatically! betwixt the substantive and the adjective, which should agree together in number, case, and gender, he made a breach thus,-stopping as if the point wanted settling;-and betwixt the nominative case, which, your Lordship knows, should govern the verb, he suspended his voice in the epilogue a dozen times, three seconds and three-fifths by a stop-watch, my Lord, each time.-Admirable grammarian!-But in suspending his voice,-was the sense suspended likervise?-Did no expression of attitude or countenance fill up the chasm?-was the eye silent?-Did you narrowly look?-I looked only at the stop-watch, my Lord.-Excellent observer !

"And what of this new book the whole world makes such a rout about?-Oh, 'tis out of all plumb, my Lord,--quite an irregular thing!-not one of the angles at the four corners was a right angle.-I had my rule and compasses, \&c., my Lord, in my pocket.-Excellent critic!

"-And for the epic poem your Lordship bid me look at,-upon taking the length, breadth, height, and depth of it, and trying them at home, upon an exact scale of Bossu's,--'tis out, my Lord, in every one of its dimensions.-Admirable connoisseur! 
"-And did you step in, to take a look at the grand picture on your way back?-'Tis a melancholy daub, my Lord! not one principle of the pyramid in any one group!-and what a price!-for there is nothing of the colouring of Titian-the expression of Rubens-the grace of Raphael-the purity of Dominichino-the corregiescity of Corregio-the learning of Poussinthe airs of Guido-the taste of the Caraccis-or the grand contour of Angelo.-Grant me patience, just Heaven! Of all the cants which are canted in this canting world,--though the cant of hypocrites may be the worst,-the cant of criticism is the most tormenting!

"I would go fifty files on foot, for I have not a horse worth riding on, to kiss the hand of that man whose generous heart will give up the reins of his imagination into his author's hands,-be pleased he knows not why, and cares not wherefore.

"Great Apollo! if thou art in a giving humor,give me,-I ask no more, but one stroke of native humor, with a single spark of thy own fire along with it,- and send Mercury, with the rules and compasses, if he can be spared, with my compliments to,-no matter."1

"When Sterne's influence began to be felt throughout Europe, in translations and imitations-zigzag journeys here and there--" says Professor Cross, "it did more than all else to free literature from the depression of the serious sentimentalism of Richardson, Rosseau, and their school."'2

It could hardly be maintained, in justice to Goldsmith, that he really intended as utilitarian the vein of morality that runs throughout his charming book; for no incident, or scene, or conversation appears to have been studied. Things just seem to happen by chance in "The Vicar of Wakefield," as they came by chance to the eccentric, but ilulstrious author. A fierce satirical spirit is not Goldsmith's. "We bless the name of an author who contrives so well to reconcile us to human nature," said Scott, referring to Goldsmith. There seems no good reason to suppose that he did not exert the same beneficial influence a half century before Scott's day.

1. "Tristram Shandy," Bk. III, Ch. xil.

2. W. L. Cross, "The Development of the English Novel," p. 76. 
Horace Walpole willingly pointed out "defects" in "The Castle of Otranto" which, he asserted, should be charged against the Italian author: "Yet 'I am not blind to my author's defects," he says apologetically in his preface to the first edition, and adds: "I could wish he had grounded his plan on a more useful moral than this; 'that the sins of fathers are visited on their children to the third and fourth generation." "1

"The business of romance," Miss Reeve says, "is, first, to excite the attention; and second, to direct it to some useful or at least innocent, end."2

To certain radicals in the last decade of the eighteenth century, the injustice of orranized society had become unbearable; and to many, natural evolutionary processes, such as those of Fielding, Sterne, Johnson, and Goldsmith, were too slow and too uncertain. More violent and revolutionary methods were deemed expedient and necessary. The one notable exponent of social and political justice, too long delayed, was William Godwin, the author of. "Caleb Williams." The sentiments of the characters are the author's own. Through his characters he makes known his ideas of political justice, and announces the real purpose of the book:

"I will tell a tale-! The justice of the country shall hear me !. . Too long have I been tender-hearted and forbearing ...

"No, I will use no daggers! I will unfold a tale!I will show thee to the world for what thou art; and all the men that live, shall confess my truth!"3

The moral of "Caleb Williams" is contained in one of the concluding reflections: "Of what use are talents and sentiments in the corrupt wilderness of society." The author's convictions concerning the state of society, including reasons for his opinions, are reflected in the preface, dated May 12, 1794:

"The following narrative is intended to answer a purpose more general and important than immediate-

1. "The Castle of Otranto." Preface to the First Edition.

2. Preface to "The Old English Baron."

3. "Caleb Williams," Ch. $\mathrm{xv}$. 
ly appears upon the face of it. The question now afloat in the world respecting things as they are is the most interesting that can be presented to the human mind. While one party pleads for reformation and change, the other extols in the warmest terms the existing constitution of society. It seems as if something would be gained for the decision of this question, if that constitution were faithfully developed in its practical effects. What is now presented to the public is not refined and abstract speculation; it is a study and delineation of things passing in the moral world; it is but of late that the inestimable importance of political principles has been adequately apprehended. It is now known to philosophers, that the spirit and character of the government intrudes itself into every rank of society. But this is a truth highly worthy to be communicated to persons whom books of philosophy and science are never likely to reach. Accordingly it was proposed, in the invention of the following work, to comprehend, as far as the progressive nature of a single story would allow, a general view of the modes of domestic and unrecorded despotism by which man becomes the destroyer of man. If the author shall have taught a valuable lesson, without subtracting from the interest and passion by which a performance of this sort ought to be characterised, he will have reason to congratulate himself upon the vehicle he has chosen."1

Thus it is clear that the new fiction was used by leading authors from Richardson to Godwin as a means to an end. The first great novelists used the story "rather as a vehicle to instruction." Walpole, the dilettante, the dabbler in things unusual and radical, dared not publish his work without at least a pretense at apology for the spurious Italian author. And the last novelist of the century to win enduring literary fame, employed his talents to teach his so-called valuable lesson, that "man is the chief enemy of man."

1. Preface to "Caleb Williams." 


\section{MEANS OF REACHING THE INNER LIFE}

"Realistic fiction," Says Professor Perry, "is that which does not shrink from the commonplace (although art dreads the commonplace) or from the unpleasant (although the aim of art is to give pleasure) in its aim to depict things as they are, life as it is."1 Professor Perry's definition of realistic fiction is sensible, comprehensive, logical, and sound. Life as it is, in respect both to the outer and inner life of the English people, is the subject matter of eighteenth-century fiction; and thus, broadly speaking every author in this period is a realist. ${ }^{2}$ Richardson called his greatest novel "a history of life and manners"; and he justified his prolixity on the ground that "there was frequently a necessity to be very circumstantial and minute, in order to preserve and maintain that air of probability which is maintained in a story designated to represent real life." 3

Fielding writes: "It is our business to discharge the part of a faithful historian, and describe human nature as it is, not as we would wish it." Later he makes it clear he will not bend human nature to comply with the received opinions about it: "I must remind such persons (those who think his scenes unnatural) that I am not writing a system, but a history, and I am not obliged to reconcile every matter of the received notions concerning truth and nature."4

Smollett declared: "I have not deviated from nature in the facts, which are all true in the main."5

Sterne found that "human nature is the same in all professions."6

1. Bliss Perry, "A Study of Prose Fiction," p. 229.

2. W. L. Cross, "The Development of the English Novel," p. 57.

3. Postscript to "Clarissa Harlowe."

4. "Tom Jones," Bk. XII, Ch. Vlit.

6. "Tristram Shandy," III, Ch. xill. 
With regard to the domestics, Walpole wrote, "My rule was nature."1

Miss Burney maintained that her heroine was the "offspring of Nature, and of Nature in her simplest attire."2

Didacticism, too, links eighteenth-century novels with realism. Richardson was interested in investigating the "great doctrines of Christianity"; and every novelist, it appears, was eager to advance the cause of morality and virtue. "I think it may fairly be claimed," says Professor Perry, "that the theory on which realism is based is in close accord with the spirit of Christianity. For the theory of realism teaches that the 'every day life of all' is worth something-if only worth describing; it teaches the reality of our present expciciences, the significant. The world becomes intelligible, interesting. It is a live world-God's world. The forces about us are real; the men and women we know are real personalities." 3 This was the basic stuff used in eighteenth-century fiction, and the theory generally understood, though not definitely formulated, upon which the novel was built.

No one can read consecutively the great novels of Richardson, Fielding, Smollett, Sterne, and Goldsmith without concluding that a unity of purpose, such as this, dominated each author. On the other hand, no one, after having read "Clarissa" and "Tom Jones," could possibly attribute both novels to the same author. Though each declared his purpose was to give a faithful picture of human nature, the finished product was, after all, life as he saw it-life interpreted by the author's own way of looking at it. "Art," says a noted French author, "is a bit of nature seen through a temperament." The use made of the materials, therefore, depends upon the taste and aims of the author who uses them.

To insure the novel's reaching the inner life of society, and thus accomplishing "the great end in view," each author had to determine what was for him the best means of presenting his material. To this end, it was necessary for each to search out and to prove his own temperament. The

1. Preface to "The Castlc of otranto."

3. Bliss Perry, "A Study of Prose Fiction," pp. 243-244; 245. 
means employed by the great novelists may be thus characterized:

I. Sentiment-provoked by analysis, pathos, and gentle humor. II. Satire, or better, ridicule-softened by wit and vigorous humor. III. Satire-mitigated by coarse humor. IV. Terror-an appeal to the emotions of curiosity, wonder, and fear. In the last class belong Walpole, (to a certain extent, Smollett, and Godwin) Miss Reeve, Mrs. Radcliffe, Beckford, and "Monk" Lewis; in the third class, Smollett alone; in the second, Fielding and Sterne; in the first, Richardson, Sterne, and Goldsmith.

"It was by his sentiment," says Professor Raleigh, "that Richardson gained an immediate and enduring popularity, and became the founder of a school of novelists." 1 And Mr. Dobson writes: "He was the pioneer of a new movement; the first certified practitioner of sentiment; the English Columbus of the analytical novel of ordinary life. Before him, no one essayed in this field to describe the birth and growth of a new impression, to show the ebb and flow of emotion in a mind distraught, to follow the progress of a passion, to dive so deeply into the human heart. . .."2

The meaning and purpose of sentiment, as understood and used by Richardson and his followers, is satisfactorily explained by Mr. Hazlitt: "The interest of the story (Pamela) increases with the dawn of understanding and reflection in the heroine: her sentiments gradually expand themselves, like opening flowers. She writes better every time, and acquires a confidence in herself, just as a girl would do, in writing such letters in such circumstances; and yet it is certain that no girl would write such letters in such circumstances. What I mean is this-Richardson's nature is always the nature of sentiment and reflection, not of impulse or situation. He furnishes his characters, on every occasion, with the presence of mind of the author. He makes them act, not as they would from impulse of the moment, but as they might upon reflection, and upon careful review of every motive and circumstance in their situation."3

1. Waiter Ralelgh, "The Engllsh Novel,", p. 160.

3. Willam Hazlitt, "English Comie Writers," p. 160. 
Sentiment is defined in the New Century Dictionary as "thought, opinion, notion; judgment; and decisions of the mind formed by deliberation or reflection." The characters, particularly in the novels of Richardson, Sterne, and Goldsmith are apt to express deliberate judgment on all matters relating to the common concerns of life. In the course of his biography, Tristram Shandy says: "I have undertaken, you see, to write not only my life, but my opinions also."1

Sterne followed Richardson in the use of sentiment, but his is sentiment of a different quality. It is far more subtle than Richardson's, and evinces an air of naturalness in keeping with the character that is not common to Richardson's. There is perfect blending of characterization and sentiment:

"My Uncle Toby was a man patient of injuries:-not from want of courage. ...-but he was a peaceful, placid nature-no jarring element in it-all was mixed up so kindly within him; my uncle Toby had scarce a heart to retaliate upon a fly.

"-Go,--says he one day at dinner, to an overgrown one which had buzzed about his nose, and tormented him cruelly all dinner-time, - and which, after infinite attempts, he had caught at last, as it flew by him;--I'll not hurt a hair of thy head;-Go,-says he, lifting up the sash, and opening his hand as he spoke, to let it escape;--go, poor devil, get thee gone; why should I hurt thee?-This world surely is wide enough to hold both thee and me."2

The Vicar, unsuccessful in the pursuit of his daughter, resolved to return home. Vexed and weary in body and in spirits, he entered a little alehouse where he remained for three weeks, brooding and railing at the misfortunes Providence had sent upon him. The fortunate appearance of a traveler at the inn restored his health and tranquility, whereupon he started homeward, condemning thus the pride that had made him refractory to the hand of correction:

1. "Tristram Shandy," I, Ch. *1.

2. "Ibld.," II, Ch. xil. 
"Man little knows what calamities are beyond his patience to bear, til he tries them: as in ascending the heights of ambition, which looks bright from below, every step we rise shows us some new and gloomy prospect of hidden disappointment; so in our descent from the summits of pleasure, though the veil of misery below may appear at first dark and gloomy, yet the busy mind, still attentive to its own amusement, finds, as we descend, something to flatter and to please. Still as we approach, the darkest object appears to brighten, and the mental eye becomes adapted to its gloomy situation."1

When friends and admirers criticised the inordinate length of his novel, Richardson replied that he was representing real life, and that it was frequently necessary to be circumstantial and minute. What the author really meant was that he was dissecting and analyzing the female heart, and that he was reporting his discoveries in letters purported to have been written by the ladies themselves. The sentiments of a female heart are manifold and varied. This is true especially when her sentiments are incited by hopes that are beyond her reach; and when they are aroused by unforeseen circumstances over which she has no control, as is the case in Richardson's novels. It would require undue length, therefore, to get Pamela's or Clarissa's sentiments uttered once. But the incessant repeating-the doubling back necessary with the letter for Pamela to tell the same incident to Mrs. Jewkes, to her parents, and to Mr. B.made very great length inevitable. "Why, sir," says Johnson, "if you were to read Richardson for the story, your impatience would be so much fretted that you would hang yourself. You must read him for the sentiment, and consider the story only as giving rise to the sentiment."2 Those who, like Johnson and Richardson, thought a book deserved praise mainly because of its sentiments on virtue and religion, made no serious objection to the length of the piece.

To make the sentiment of the characters seem natural, and to make them doubly strong in accomplishing the great

1. "The Vicar of Wakefleld," Ch. xviii.

2. Boswell's "Life of Johnson," Birkbeck Hill Ed., II, p. 175. 
end in view, the letter method best suited Richardson's purpose. These sentiments, he declared, were provoked while the heart was agitated by hopes and fears, on events undecided, and written after a moment's intense reflection; or, as he put it, "to the moment." Due to this fact, Richardson argued, the letter method had much in its favor to commend it. The length of the piece, though necessary on account of it, was nevertheless excusable:

"The nature of familiar letters, written, as it were, to the moment, while the heart is agitated by hopes and fears, on events undecided, must plead an excuse for the bulk of a collection of this kind. Mere facts and characters might be comprised in a much smaller compass: but, would they be equally interesting?'”1

"All the letters are written," he says in another place, "while the hearts of the writers must be supposed to be wholly engaged in their subjects (the events at the time generally dubious) : so that they abound not only with critical situations, but with what may be called instantaneous descriptions and reflections (proper to be brought home to the breast of the youthful reader)..."2 "Much more lively and affecting," he makes one of his characters say, "must be the style of those who write in the height of a present distress; the mind tortured by the pangs of uncertainty (the events then hidden in the womb of fate); than the dry, narrative, unaimated style of a person relating difficulties and dangers surmounted, can be. .."

Richardson's design in using the epistotary style is clearly set forth in these words:

"The letters and conversations, where the story makes the slowest progress, are presumed to be characteristic. They give occasion, likewise, to suggest many interesting personalities, in which a good deal of the instruction essential to a work of this nature is conveyed."3 In other words, when Miss Howe wrote to Clarissa in the very beginning, . "Every eye, in short, is upon you with the expectation of an example," she doubtless meant to caution Clarissa against letting fall in a careless manner those "delicate sentiments,"

1. Preface to "SIr Charles Grandison."

2. Preface to "Clarissa Harlowe."

3. Postscript to "Clariosa Harlowe." 
which, in all probability, they would exchange; for they would, she presumed, not only arrest attention, but also arouse discussion and comment. Such was Richardson's hope and expectation; and the letter method had much to do with the success of his plans. It gave ample opportunity for that breadth and depth of sentiment which is natural to the individual, not only when he is quiet and pensive, but especially so when he is aroused and agitated, perhaps at some pinnacle moment or crisis of life. "Not only did Richardson aim to teach men and women, boys and girls," says Professor Cross, "that righteousness will be rewarded and sin punished either here or hereafter, ... but he sought to arouse discussion on special cases of conduct.""

But the sentiment of Richardson, Goldsmith, and Sterne was not always the direct result of deliberation; it was frequently the expression of the emotions without the aid of judgment; and thus it gave rise to what has sometimes been called "sensibility."' In Richardson's Lovelace, the reader meets perhaps the first man of "feeling" in the English novel. Mr. Lovelace did not like tragedies, and frankly gave his reason for not liking them:

"Yet, for my own part," he wrote to Belford, "I loved not tragedies; though she (Clarissa) did, for the sake of the instruction, the warning, and the example generally given in them.

"I had too much "feeling"; I said. There was enough in the world to make our hearts sad, without carrying grief into our diversions, and making the distress of others our own."3

Sadness and grief is exactly what the author of "Clarissa Harlowe" forced upon his characters; they, in turn, transmitted to the reader the effect of this emotion. But though Richardson was, as Professor Raleigh maintains, "the inaugurator of a century and a half of hyperaesthesia,"4 he himself, it seems, never tried to define the new

1. W. L. Cross, "The Development of the Engltsh Novel," p. 39.

2. "Sentimentalism, I suppose means, roughly speaking, indulgence in emotion for its own sake. The sentimentalist does not weep because painful thoughts are forced upon him, but because he finds weeping pleasant in itself. He appreclates the "luxury of grlef"."-Leslle Stephen. "Tnglish Literature and Soclety in the Eighteenth Century." pp. 148-149.

3. "Clarissa Harlowe" IV, Letter Xxxill, 101. 
emotionalism; he left this task for Mrs. Radcliffe, who, years later, defined it as "a dangerous quality which is continually extracting the excess of misery or delight from every surrounding object."1

When Pamela was on the point of departure from Mr. B.'s, she recounted in a letter to her parents her recent trials. A touching lecture from Pamela had somewhat softened Mr. B.'s heart, but did not prevent a fresh attempt upon her virtue-an attempt in which her trusty Mrs. Jervis was an accompice:

"O Mrs. Jervis!" she exclaims, "what have you done by me?- . . . Wretched, wretched Pamela, where shalt thou expect a friend, if Mrs. Jervis joins to betray me thus? She made so many protestations (telling me all, and that he owned I had made him wipe his eyes two or three times, and said she hoped it would have a good effect, and remembered me, that I had said nothing but what would rather move compassion than resentment), that I forgave her."2

"In 1749 appears Richardson's 'Clarissa Harlowe' in eight volumes, which from your present lecturer's point of view is quite sufficiently described as a patient analysis of the most intolerable crime in all history of fiction, watered with an amount of tears and sensibility as much greater than that in 'Pamela' as the cube of eight volumes is greater than the cube of four volumes."

Observe the attendants upon Clarissa during her last hours: "In this heart-moving attitude she (Clarissa) appeared to us when we approached her, and came to have her lovely face before us," writes Mrs. Lovick. "The Colonel, sighing often, gazed upon her with his arms folded, and with the most profound and affectionate attention; till at last, on her starting and fetching her breath with greater difficulty than before, he retired to a screen that was drawn before her house, as she calls it. ... Retiring thither he drew out his handkerchief, and overwhelmed with grief, seemed unable to speak."

I never, my best-beloved and dearest cousin, said

1. "The Mysteries of Udolpho," Ch. v.

3. Sidner Lanler, "The English Novel," p. 189. 
he (with eyes running over), shall forgive myself, that I did not attend you sooner."1

"She (Clarissa) had fatigued herself so much ... that she sunk her head upon her pillows, ready to faint; and we withdrew to the window, looking upon one another, but could not tell what to say; and yet both seemed inclinable to speak: but the motion passed over in silence. Our eyes only spoke; and that in a manner neither's were used tomine, at least, not till I knew this admirable creature."2

"Her nurse was kneeling between the window and Mrs. Smith, her arms extended." In one hand she held an ineffectual cordial, which she had just been offering to her dying mistress; her face was swollen with weeping (though used to such scenes as this); and she turned her eyes toward me, as if she called upon my by them to join in the helpless sorrow; a fresh stream bursting from them as I approached the bed."3

"Poor Mrs. Norton is come. She was set down at the door; and would have gone upstairs directly, but Mrs. Smith and Mrs. Lovick being together in tears, and the former hinting too suddenly to the truly-venerable woman the fatal news, she sunk down at her feet in fits. . .

"She was impatient to see the corpse. The women went up with her. But they owned that they were too much affected themselves on this occasion to describe her extremely affecting behaviour. With trembling impatience she pushed aside the coffin-lid. She bathed the face with her tears, and kissed the cheek and forehead, as if she were living. ..."

And such sentiment seems to have affected the eighteenth-century reader in a similar manner. Professor Gellert of Leipsig, who translated "Pamela" and "Sir Charles

1. "Clarissa Harlowe," VII, Letter xxii.

Perhaps the most sentimental of all English novels is Henry Mackenzle's "The Man of Feeling," 1771. The author reminds his readers, needlessly that the hero, Mr. Harley, has a "feellng heart." (Ch, xxix), needlessly,

was often "bathed with tears." Once when a young

presence, "Harlcy kissed of her tears as they flowed girl cried in his

every kiss." (Ch. Xxxy) But the mere "recollection" of tears was enough to make him weep, (Ch. xxvili)

2. "Clarissa Harlowe," vif, Letter xxii.

3. "Ibld." Letter xxix.

4. "Ibld,", VII, Letter xxxy. 
Grandison," frankly confessed: "I have formerly wept away some of the most remarkable hours of my life in a sort of delicious misery, over the seventh volume of 'Clarissa' and the fifth of 'Grandison.' " 'In a sort of delicious misery,the words should not be forgotten, for they precisely express the sensation aroused and enjoyed by contemporary readers of Richardson, and of the sentimental literature that followed in his wake of tears.'1

Aaron Hill describes the effect of the concluding volumes of "Clarissa" on his family circle: "At this moment I have three girls around me-each a separate volume in her hand, and all their eyes like a wet flower in April."

The stream of emotionalism that runs gently through "The Vicar of Wakefield"-a stream that is much clearer and purer than either Richardson's or Sterne's-is sometimes swollen, but seems never to overflow its banks. Dick's announcing that his sister Livy had gone, would have set the Vicar in a towering rage had it not been for his appeasing emotionalism: "But it is not, it is not," he cries, "a small distress that can wring tears from these eyes, that have not wept for so many years. My child!-To undo my darling!" And his wife, he tells us, "could hardly speak for weeping." 2

If Richardson's characters seem to be "extracting the excess of misery .... from every surrounding object," and are thus illustrating the first phase of Mrs. Radcliffe's definition of sentimentalism, she makes her own characters illustrate the second phase of the definition, because they are "continually extracting the excess . . . of delight from every surrounding object"-especially from the objects of physical nature.

"The serenity and clearness of the air in these high regions were particularly delightful to travelers," she says; "it seemed to inspire them with a finer spirit, and to diffuse indescribable complacency in their minds. They had no words to express the sublime emotions they felt."'

1. W. L. Phelps, "The Advance of the English Novel," pp. 75-76. 2. "Micar of Wakefeld," Ch, Xvili, 
"While the distant perspective of the valley was lost in the yellow mist of moon-light, the travellers sat for some time wrapped in the complacency which such scenes inspire."1

"These scenes, said Valancourt, at length, soften the heart like the note of sweet music, and inspire that delicious melancholy, which no person, who had felt it once, would resign for the gayest pleasures. They awaken our best and purest feelings, disposing us to benevolence, pity, and friendship. Those whom I love, I always seem to love more in such an hour as this. His voice trembled and he paused."2

Thus in the naturalistic and in the romantic schools there was represented in sentimentalism the same mood. It is that vague indefinable feeling - the uneasy, restless feeling of discontent peculiar to the life and thought of the eighteenth century. "To assign any precise philosophical meaning to sentimentalism would be an absurd attempt," says Mr. Leslie Stephen, because "it is much more a social than an intellectual phenomenon."3 This feeling of discontent with the social and political order is represented in fiction by the sentimentalists. Whether then the individual novelist is classed finally with the naturalistic or the romantic school, makes little difference; for both of them were trying to satisfy the same yearning for change.

Mr. Hazlitt discovers at least three different kinds, or degrees of the laughable: the accidental contradiction of our expectations; the ludicrous, arising out of the improbable; and the ridiculous. The latter, which is one of man's own seeking, he regards as more refined than either of the others, but he thinks that it carries with it a tinge of unpleasantness. The ridiculous he defines as "that which is contrary not only to custom, but to sense and reason, or is a voluntary departure from what we have a right to expect from those who are conscious of absurdity and propriety in words, look, and actions." "4

\footnotetext{
1. "The Mysterles of Udolpho," Ch. iv.

3. Leslie Stephen, "History of English Thought in the Elghteenth Century,"

4. Whling Hazllt, "The Engllsh Comic Writers," Lecture I, p. 5.
} 
Henry Fielding reached the inner life of English society by ridiculing, with his infectious wit and humor, the follies and vices of his day. He declared in the dedication of "Tom Jones" that he had employed all the wit and humor at his command "to laugh mankind out of their favorite follies and vices." "Life everywhere furnishes an accurate observer with the ridiculous," he maintains, and he expounds for his readers the meaning of the term:

"The Ridiculous only . . . falls within my province in the present work. Nor will some explanation of this word be thought imnertinent by the reader, if he considers how wonderfully it hath been mistaken, even by writers who have professed it: for to what but such a mistake can we attribute the many attempts to ridicule the hlackest villanies, and, what is yet worse, the most dreadful calamities? What could exceed the absurdity of an author who would write the comedy of Nero, with the merry incident of ripping up his mother's belly? or what would give greater shock to humanity than an attemnt to expose the miseries of poverty and distress to ridicule? And yet the reader will not want much learning to suggest such instances to himself.

"Besides, it may seem remarkable that Aristotle, who is so fond and free of definition, hath not thought proper to define the Ridiculous. Indeed, where he tells us it is proper to comedy, he hath remarked that villany is not its object, but he hath not, as I remember, positively asscrted what it is. Nor doth the Abbe Bellegrade, who hath written a treatise on this subject, though he shows us many species of it, once we trace it to its fountain.

"The only source of the true Ridiculous (as it appears to $\mathrm{me}$ ) is affectation. But though it arises from one spring only, when we consider the infinite streams into which this one branches, we shall presently cease to admire at the copious field it affords to an observer. Now, affectation proceeds from one of these two causes, vanity or hypocrisy: for as vanity puts us on affecting false characters, in order to purchase applause, so hypocrisy sets us on an endeavour to avoid censure, by concealing our vices under an appearance of their opposite virtues. And though these two causes are often confounded (for there is some difficulty in distinguishing them), yet as they proceed from very different motives, so they are as clearly distinct in their 
operations: for, indeed, the affectation which arises from vanity is nearer to truth than the other, as it hath not that violent repugnancy to nature to struggle with which that of the hypocrit hath. It may be likewise noted that affectation doth not imply an absolute negation of those qualities which are affected; and, therefore, though, when it proceeds from hypocrisy, it be nearly allied to deceit; yet when it comes from vanity only, it partakes of the nature of ostentation; for instance, the affectation of liberality in a vain man differs visibly from the same affectation in the avaricious; for though the vain man is not what he would appear, or hath not the virtue he affects, to the degree he would be thought to have it, yet it sits less awkwardly on him than on the avaricious man, who is the very reverse of what he would seem to be.

"From the discovery of this affectation arises the Ridiculous, which always strikes the reader with surprise and pleasure; and that in a higher and stronger degree when the affectation arises from hypocrisy than when from vanity; for to discover anyone to be the exact reverse of what he affects is more surprising, and consequently more ridiculous, than to find him a little deficient in the quality he desires the reputation of. I might observe that our Ben Jonson, who of all men understood the Ridiculous the best, hath chiefly used the hypocritical affectation.

"Now, from affectations only, the misfortunes and calamities of life, or the imperfections of nature, may become the objects of ridicule. Surely he hath a very ill-framed mind who can look on ugliness, infirmity, or poverty, as ridiculous in themselves: nor do $I$ believe any man living, who meets a dirty fellow riding through the streets in a cart, is struck with an idea of the Ridiculous from it; but if he should see the same figure descend from his coach and six, or bolt from his chair with his hat under his arm, he would then begin to laugh, and with justice. In the same manner, were we to enter a poor house and behold a wretched family shivering with cold and languishing with hunger, it would not incline us to laughter (at least we must have very diabolical natures if it would); but should we discover there a grate, instead of coals, adorned with flowers, empty plate or china on the sideboard, or any other affectation of riches or finery, either on their persons or in their furniture, we might then indeed be excused for ridiculing so fantastical an appearance. 
Much less are natural imperfections the object of derision: but when ugliness aims at the applauses of beauty, or lameness endeavours to display agility, it is then that these unfortunate circumstances, which at first moved our compassion, tend only to raise our mirth.

". . . Great vices are the proper objects of our detestation, smaller faults, of our pity; but affectation appears to me the only true source of the Ridiculous."1

In his Invocation beginning the thirteenth book of "Tom Jones," Fielding calls to his aid, "First, Genius: thou gift of heaven; without whose aid in vain we struggle against the stream of nature. . . Teach me ... to know mankind better than they know themselves. Remove that mist which dims the intellects of mortals, and causes them to adore men for their art, or to detest them for their cunning, in deceiving others, when they are, in reality, the objects only for ridicule, for deceiving themselves. Strip off the disguise of wisdom from self-conceit, of plenty from avarice, and of glory from ambition. Come, thou that hast inspired thy Moliere, thy Shakespeare, thy Swift, thy Marivaux, fill my pages with humor, till mankind learns the goodnature to laugh only at the follies of others, and the humility to grieve at their own."2

It is clear from this exposition of this theory that Fielding was not primarily a satirist; he makes it plain that he entertains a kindly feeling towards the weaknesses of human nature. Good nature, he always emphasized as a virtue-a virtue that comprehended all the others. Every hypocrisy and sham he ridiculed by his inimitable wit and humor, but declared again and again that he had no intention to vilify any one: "I defy the wisest man in the world from turning a true good action into ridicule," he makes Joseph Andrews say.

Fielding believed that every man has some good in himself. In the last analysis, "goodness of heart" characterizes most men; hence he portrays men and women neither totally good nor totally bad. Pure satire was too strong for him. Ridicule would better enable him to pass over the weaknesses of mankind, and to regard them merely as weaknesses-

1. Preface to "Joseph Andrews."

2. "Tom Jones," Bk. XIII, Ch. $i$. 
and therefore, not as proper objects of ridicule. His observation was so keen, his experience so broad, that he could not hold up one man to the contempt of a small circle; but would rather hold the mirror to thousands that they might see their deformity. "For pedantry and all forms of hypocrisy," says Professor Metcalf, "he had infinite sarcasm, and for human frailty tolerant sympathy."

"What he did," Professor Cross remarks, "was to ridicule-satirize is too strong a word-fashionable society of his own day. Wild and his crew were really the beaus, politicians, and fine ladies of questionable reputation of the middle and upper classes from whom he removed the masque of convention and pretence. When their motives were laid bare, society was discovered to be the same in all ranks, for human nature is everywhere the same. Fielding stripped his fine ladies and fine gentlemen of their language, and let them give vent, as they no doubt of ten did in private quarrels, to their emotions in the speech of Billingsgate."2

In the introductory chapter to the last book of "Tom Jones," the author makes this leave-taking declaration to his readers: "And now, my friends, I take this opportunity $\ldots$ of heartily wishing thee well. If I have been an entertaining companion to thee, I promise thee it is what $I$ have desired. If in anything I have offended, it was really without my intention. Some things, perhaps, here said, may have hit thee or thy friends; but I do most solemnly declare they were not pointed at thee or them."3

The author of "Joseph Andrews" was not a religious enthusiast, if we may regard Parson Adams's opinion of Whitefield in chapter eighteen as Fielding's own; but of all hypocritical affectation, perhaps none was more detestable to him than that of virtue and religion. His wit is never more cutting, his humor never more glaring, than when he artfully shoves Parson Adams into the pigsty as a prelude to the expose of Parson Trulliver's hypocrisy. The simple Adams had no thought other than that his brother of the cloth would gladly supply him with the needed funds. But here was Fielding's chance to ridicule one of the most pre-

1. T. C. Metcalf, 'Henry Fielding, Critic,' "Sewanee Review," XIX, p. 145. 2. W. L. Cross, "The History of Henry Fielding," III, pp. 204-265.

3. "Tom Jones," Bk. XVIII, Ch. $\mathrm{I}$." 
valent of all affectations, charity. Instead of giving Adams the money he had requested, Trulliver gave the parson a sound beating, and cast him out of his house under pretense of his being a robber. Later, however, charity came from an unexpected source. Fielding found in the world that lack of charity with which he charged Partridge. When the beggar asked alms, Partridge "gave him a severe rebuke, saying, 'every parish ought to keep its own poor.' Jones then fell a laughing, and asked Partridge 'if he was not ashamed, with so much charity in his mouth, to have no charity in his heart.' 'Your religion,' says he, 'serves you only for an excuse for your faults, but is no incentive to your virtue." "1

Smollet's use of satire and humor differs from Fielding's, in that it is bitterer. The reason was, it seems, that this author could discover but few of the sweets of life. His humor is coarser than Fielding's, too, because he saw not human nature in the broader sense, but as a rather restricted group of men and women whose chief characteristic was their eccentricity. "Of all kinds of satire," he says in one of his prefaces, "there is none so entertaining and universally improving, as that which is introduced, as it were, occasionally, in the course of an interesting story, which brings every incident home to life."2

Sterne, much as did Fielding, tried to reach the inner life of the English people by ridiculing their affectations. Sterne struck boldly at assumed gravity: "Yorick had an invincible dislike and opposition in his nature to gravity;not a gravity as such; for where gravity was wanted, he would be the most grave or serious of mortal men for days and weeks together; but he was an enemy to the affectation of it, and declared open war against it, only as it appeared a cloak for ignorance, or for folly: and then, whenever it fell in his way, however sheltered and protected, he seldom gave it much quarter."3

Sterne defines gravity thus: The "very essence of gravity was design, and consequently deceit; - twas a taught trick to gain credit of the world for more sense and knowl-

1. "Tom Jones," Bk. XII, Ch. IV.

2. Preface to "Roderick Random."

2. "Tristram Shandy," I, Ch. Xi." 
edge than a man was worth; and that, with all its pretensions,-it was no better, but often worse than what a French wit had long ago defined it,-viz. 'A mysterious carriage of the body to cover the defects of the mind';--which definition of gravity, Yorick,with greatest imprudence, would say, deserved to be wrote in letters of gold."1

Sterne's humor is very difficult to analyze. To surprise the reader with the least expected incidents of life when he least expects them, seems to be the essence of his theory. This he clearly and rather forcibly expressed in the following: "What these perplexities of my uncle Toby were,--'tis impossible for you to guess:-if you could,-I should blush; not as a relation-not as a man,-not even as a woman,but I should blush as an author; inasmuch as I set so small store by myself upon this very account, that my reader has never yet been able to guess anything: and in this, $\mathrm{Sir}, \mathrm{I}$ am of so nice and singular humor, that if I thought you was able to form the least judgment, or probable conjecture to yourself of what was to come in the next page,-I would tear it out of my book."2

But the author of "Tristram Shandy" was concerned not only about making people laugh solely for the sake of laughing; he was concerned quite as much in having them laugh at the conceit of others, particularly those of the canting critics of his time, whom he no doubt detested roundly. The bitter humor in chapter twelve of the third book of "Tristram Shandy" must have been just as effective at correcting the fetishism of Neo-Classic canons, as was Felding's humor and ridicule at laughing men out of their favorite follies and vices. "It must be admitted," says Professor Saintsbury, "that there are few better instances of the combined sprightliness and ingenuity of Sterne's humor. 'Befetiched with the bobs and trinkets of criticism, is in reality even happier than the 'stop-watch,' and of an extraordinary propriety. Though he did 'fetch it from the coast of Guinea,' nothing was even less far-fetched or more homedriven. The 'nothing of the colouring of Titian' is equally happy in its rebuke of the singular negativeness-the atten-

1. "Tristram Shandy," $\mathrm{I}, \mathrm{Ch}, \mathrm{xl}$,

2. "Ibld.," I, Ch. Xxv: 
tion to what is not there, not to what is-of Neo-Classicism; while the outburst, again world-known, as to the 'tormenting cant of criticism,' and the ingenious and thoroughly English application of this cant itself to the eulogy of the curse of Ernulphus, are all too delightful, and have been too effective for good, not to deserve the heartiest acknowledgement."1

The modern reader is inclined to smile at Sterne's dots, dashes, and asterisks; his blank, and his marble pages, and other absurdities; but the author, no doubt, laughed in his sleeve at them, too. All of this and more was clearly a part of his design to free the novel in form and in content from the narrowing conventionalities of Augustan canons. He characterizes one of his marble pages as "the motly emblem of my work." Of his dots, dashes, blanks, and other curious devices, he gives the following explanation: "As no one, who knows what he is about in good company, would venture to talk all;-so no author, who understands the just boundaries of decorum and good breeding, would presume to think all; the truest respect which you can pay to the reader's understanding, is to halve this matter amicably, and leave him something to imagine, in his turn, as well as yourself.

"For my own part, I am eternally paying him compliments of this kind, and do all that lies in my power to keep his imagination as busy as my own."2

"I would go fifty miles afoot," he declares, "to kiss the hand of that man whose generous heart will give up the reigns of his imagination into his author's hands,-be pleased he knows not why, and cares not wherefore." And, as for himself, he adds:

"Great Apollo! if thou art in a giving humor,-give me, -I ask no more, but one stroke of native humor, with a single spark of my own fire along with it,--and send Mercury, with the rules and compasses, if he can be spared, with my compliments to,-no matter."3

"Tristram Shandy" was published in 1759-67. In this curious hodgepodge, Sterne consciously tried to smask ev-

1. George Saintsbury, "A History of Criticism," III, p. 87.

2. "Tristram Shandy", If, Ch. $x$.

3. "Ibld.," III, Ch. Xil. 
THE EIGHTEENTH-CENTURY NOVEL

ery literary convention. Fully determined to tell his stories in his own way, he says: "Of all the several ways of beginning a book which are not in practice throughout the known world, I am confident my own way of doing it is the best. I'm sure it is the most religious,-for I begin with writing the first sentence,- -and trusting to Almighty God for the second."1

Why he thought it necessary to write such a book, he implies in the following: "In a word my work is digressive, and it is progressive too,- and at the same time."

"This, Sir, is a very different story from that of the earth's moving around her axes in her diurnal rotation, with her progress in her elliptic orbit, which brings about the year, and constitutes that variety and vicissitude of seasons we enjoy-though I own it suggested the thought,-as I believe the greatest of our boasted improvements and discoveries have come from such trifling hints.

"Digressions, incontestably, are the sunshine;--they are the life, and soul of reading! take them out of this book, for instance,-you might as well take the book along with them; - one cold eternal winter would reign in every page of it: restore them to the writer;--he steps forth like a bridge-groom, bids All-hail; brings in a variety and forbids the appetite to fail."'2

Ten years before Sterne's work, Smollett's "Roderick Random" and Fielding's "Tom Jones" show unmistakable evidences of dissatisfaction with Neo-Classic canons of criticism. "Reader, I think proper, before we proceed any farther together," says Fielding, "to acquaint thee that I intend to digress, through this whole history, as of ten as I see occasion, of which I am myself a better judge than any pitiful critic whatever; and here I must desire all those critics to mind their own business, and not to intermeddle with affairs or works which no ways concern them; for till they produce the authority by which they are constituted judges, I shall not plead to their jurisdiction."3

Both Richardson and Fielding, however, were, in gen-

1. "Tristram Shandy," VuI, Ch. 11.

3. "Tom'.Jones," Bk. L, Ch. 11. 
eral, in sympathy with the Classicists' rules of restraint. They tried to be real, to be sane, and to restrain the imagination. Naturally by 1765 readers had grown somewhat tired of Richardson's minute analysis of character and emotions; and they were not a little weary of the everlasting exposure and ridicule of the common concerns of every-day life. Reaction was inevitable. The third quarter of the century reveals an inclination, on the part of authors and readers, to turn their backs on realities, and return to magic, mystery, and chivalry. 


\section{CHAPTER V}

\section{THE “GOTHIC” NOVEL AND ROMANTICISM}

Authors began turning toward the Middle Ages, with renewed interest in Chivalry and in things mediaeval, during the fifth decade of the century. But the first open revolt in opposition to the pronounced hatred of the "Gothic" in literature and art was in 1764 when Horace Walpole published his "Castle of Otranto," the first novel after the new fashion. Concerning this innovation in literary art, Walpole wrote to Monsieur de Beaumont, March 18, 1765:

"When I had the honor of seeing you here, I believe I told you that I had written a novel, in which I was flattered to find that I had touched an effusion of the heart in a manner similar to a passage in the charming letters of Marquis de Roselle. I have since that time published my little story, but was so diffident of its merits, that $I$ gave it as a translation from the Italian. Still I should not have ventured to offer it to so great a mistress of that passion as Madam de Beaumont, if the approbation of London, that is, of a country to which she and you, Sir, are so good as to be partial, had not encouraged me to send it to you. After I have talked of the passions, and the natural effusions of the heart, how will you be surprised to find a narrative of the most improbable and absurd adventures! How will you be amazed to hear that a country of whose good sense you have an opinion should have applauded so wild a tale! But you must remember, Sir, that whatever good sense we have, we are not yet in any light chained down to precepts and inviolable laws. ... You will not, I hope, think I apply these mighty names (Aristotle, Shakespeare, Milton, and Addison) to my own case with vanity, when it is only their enormities that I quote, and that in defence, not of myself, but of my countrymen, who have had good humor enough to approve the visonary scenes and actors in "The Castle of Otranto."

"To tell you the truth, it was not so much my intention to recall the exploded marvels of ancient romance, as to blend the wonderful of old stories with 
the natural of modern novels. The world is apt to wear out any plan whatever. . . Madame de Beaumont must forgive me if I add, that Richardson had, to me at least made that kind of writing unsupportable. I thought the 'nodus' was become 'dingus vindice,' and that a god, at least a ghost, was absolutely necessary to frighten us out of too much sense. .."1

Macaulay's judgment of Walpole was that "in everything in which he busied himself-in the fine arts, in literature, in public affairs-he was drawn by some strange attraction from the great to the litlle, and from the useful to the odd. . 2" Certainly the oddities of "The Castle of Otranto" must be apparent to any one who compares the content and the structure of this novel with that of its predecessors, "Clarissa Harlowe" and "Tom Jones." But the author's intention was, he said, "to blend the wonderful of the old (romantic) stories with the natural of the modern novels." This inovation he tried to effect regardless of whether or not he knew thoroughly the spirit of the times he desired to bring back. The result was a novel that proved to be neither romantic nor realistic. It is, therefore, when we consider this book as the first conscious attempt to introduce the life of the Middle Ages into the new type of prose narrative, and thus malke due allowance for the author's extravagances, that its oddities lose much of their annoying and distracting tendencies.

"A reactionary movement," says Mr. Leslie Stephen, "may gain some strength from the theories to which it is opposed; for thought generally progresses by antagonism."3 Walpole was antagonistic. He was reactionary against the accepted canons of his day, but he never fully disregarded them. To blend the wonderful of the old with the natural of the new, was his announced purpose. But "romanticism," says Professor Stoddard, "is born of dissatisfaction with the canons of authority; it constantly and consciously searches for a new law in place of that which was ruled."4 The return to romanticism in the middle of the eighteenth century, therefore, was due chiefly to existing dissatisfac-

1. Cunningham, "Letters of Horace Walpole," IV, Letter No. 971

2. Macaulny's Works. "Critical and Histor!cal Essays," vI. pp." 2-3.

3. Leslie Stephen, "Hlstory of English Thought in the Elghteenth Century,"

4. F.' H. Stoddard, "Evolution of the English Novel," p. 130. 
- tion with Augustan thought and manner of expression. In fiction, this dissatisfaction was voiced mainly through the so-called "Gothic" novel, which began with Walpole's "Castle of Otranto," 1764.

It is the purpose of this chapter to study the "Gothic" novel in the latter part of the eighteenth century with the view to determine its relation to English Romanticism, and to point out in what manner and to what extent it may have affected the life and thought of the time.

From Thales of Miletus to Herbert Spencer is a long way, but the current of thought is continuous. Man is ever striving toward a more perfect conception and realization of the true, the beautiful, and the good. But the history of philosophy shows plainly that between one period of time and another of world progress, there are lines of demarkation, and that the divergences and differences are due to change of thought. When Tennyson wrote, "Watch what main-currents draw the years," he was doubtless inviting us to cast a retrospective glance overe preceding ages and to observe how great systems of thought have given way before the onrushing tide of greater and stronger ones. The stronger force, slowly thrusting back its head-waters like a great river system, taps what was formerly the main stream, and thus it diverts the shallow current from the weaker one into its own channel. The pirate steals in upon its prey until it perforates the conduit, and leaves the bed of the old stream high and dry.

We are reminded of similar processes in the streams of thought that have crystallized into literature; and there are no better instances of this than Classicism and Romanticism throughout the last half of the eighteenth century. On the one hand was the seemingly non resistent, self conscious pseudo-classicism, with its intellectuality and its enthronement of reason; its repressed personal emotion, and its restrained imagination. Adherents of this system of thought were often conscious imitators, and therefore much of their polished wit and satire had but little interest beyond the writer's day and age. Opposed to eighteenth-century classicism, was the romantic movement, unconscious, subjective, full of the passion and inspiration of 
the individual. The imagination, left free and unrestrained to determine what the content and the tone should be, made it relatively certain that the best literature inspired by this vital force would be for all time. Gradually but surely wearing its way beneath the old system of thought, by the end of the eighteenth century romanticism had tapped the main-current of pseudo-classicism, and had turned the stagnant Augustan waters from their even channel. Thus "the dry bones of classicism" were left to crumble and decay upon the peneplain of the eighteenth century.

If we attempt to define romanticism, we very soon learn that our efforts are futile. It is too broad and too comprehensive for limitation, and too inclusive for classification. Analysis of several attempts to define the movement will convince us that the lawyer's clerk was right when he said, "Romanticism, my dear sir! No, of a surety it is neither the disregard of the unities, nor the alliance of the comic and tragic, nor anything in the world expressible by words."1 But of course attempts to define it have been made.

Professor Hedge reminds us that we speak of romantic characters, romantic situations, romantic scenery, and then asks what we mean by this expression. His reply is, "Something very subtle, undefinable, but felt by all. If we analyze the feeling we shall find," he thinks, "that it has its origin in wonder and mystery. It is the sense of something hidden, of imperfect revelation." $\mathrm{He}$ then applies the meaning of the term to scenery: "The woody dell, the leafy glen, the forest path which leads one knows not whither, are romantic; but the public highway is not. Moonlight is romantic as contrasted with daylight. The winding secret brook, 'old as the hills that feed it from afar,' is romantic as compared with the broad river rolling through level banks."2

Victor Hugo called it "liberalism in literature." Some have long ago concluded that the "essence of romanticism is individualism"; and still others are quite certain that "ro-

1. See H. A. Beers, "A History of English Romanticism in the Eighteenth

7rederic Henry Hedge, 'Classic and Romantic," "Atlantic Monthly," March,
1886 . 
manticism is the alliance of the playful and serious, of the grotesque and the terrible, of the jocose and the horrible."1 "The essence of romanticism is the freedom of the individual," says Professor Stoddard. "The method of romanticism," he says, "is a departure from the contemporaneous. . . Romanticism departs, from the ordinary, from the accepted, from the contemporaneous, from the probable, from the reasonable."2 And lastly, Professor Beers bases his "History of English Romanticism" on the thesis, that "romanticism is the reproduction in modern art or literature of the life and thought of the Middle Ages."

Each definition is inadequate and unsatisfactory. The reason is clear: but one phase of the movement is included. If by some process of compounding all could be fused into one definition, we might be induced to accept it. In the meantime, we must be content to analyze and expound the chief characteristics of the movement-particularly such as appear to have been constructive forces in the development of the novel.

"The beginning and presence of a creative, romantic movement," says Professor McClintock, "is almost always shown by the love, study, and interpretation of physical nature."4

"It was one of Emily's earliest pleasures to ramble among the scenes of nature; nor was it in the soft and glowing landscape that she most delighted; she loved more the wild wood-walks that skirted the mountains; and still more the mountain's stupendous recesses, where the silence and gradeur of solitude impressed a sacred awe upon her heart, and lifted her thoughts to the God of Heaven and Earth."5

In sharp contrast to pseudo-classicism, which had confined itself to clubs, to coffee houses, and to drawing rooms, the spirit of romanticism sent man back to the heart of nature for his inspiration.

1. For a comptlation of expressions in answer to the question, "What is Romnnticism?" and for a brief but concise and helpful analysis of these definitions, see Professor W. L. Phelps's Introduction in his remarkable little bools, "The Beginnings of the English Romantlc Movement."

2. F. H. Stoddard, "Evolution of the English Novel," p. 131.

3. H. A; Beers, "A History of English Romanticism in the Elghteenth Cen-

4. Quoted in H. A. Beers's, "History of English Romantlelsm in the Eigh-

5. "The Mysteries, of Udolpho," Ch. i. 
"Poverty. .. cannot deaden our taste for the grand and the beautiful," Emily contended, "nor deny us the means of indulging it; for the scenes of nature-those sublime spectacles, so infinitely superior to all artificial luxuries-are open for the enjoyment of the poor as well as the rich. . . We retain, then, the sublime luxuries of nature, and lose only the frivolous ones of art.".1

"With a small osier basket to receive plants, and another filled with cold refreshments, ... they wandered away among the most romantic and magnificent scenes, nor suffered the charms of Nature's lovely children to abstract them from the observance of her stupendous works."2

The limitations imposed upon the imagination and the emotions by strict adherence to Augustan rules, no doubt made many a sincere heart feel toward this unnatural bondage of the city much as did St. Aubert, who "retired from the multitude, but more in pity than in anger, to the scenes of simple nature."2

The true spirit of romanticism reinstated the common man to his rightful place in life and in literature. This was due, in large measure, to a better understanding of the human heart, together with a purer human sympathy. Pope, the greatest of the Augustans, spent valuable time in writing an extensive poem that depicted well enough the social foibles and idle vanities of his day, but he found no time for thought of, and little sympathy for, the man on the lower terraces of life. When the court fop, Lord Petre, snipped a lock of hair from the flowing curls of a pretty maid of honor named Arabella Fermor, the two families were plunged into a quarrel. So important was this trival incident and so terrific the petty clash, that it provided the motivating element and much of the material for a mock heroic-epic; but the poet would not throw open the blinds of the drawing-room long enough to see the servant Caleb Williams struggling to rid himself of repressive social conventions. Addison delighted polite society but had no cheering message for plain people. Swift's work was frightful satire. Even Johnson, with all his kindness, had

1. "The Mysteries of Udolpho," Ch. vi.
2. "Ihld.," Ch. 1. 
little feeling for the masses of mankind. "Our proper bliss depends upon what we blame," Pope taught his age to think. If the common man is down, kick him; if he is up, trudging but slowly along, hold him in full view that the world may ridicule his weakness and his failures. Such was the attitude towards the common man that prevailed during the first half of the eighteenth century.

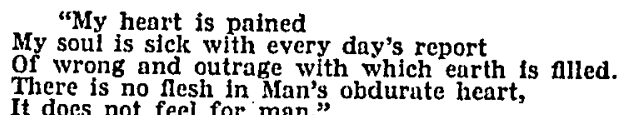

Thus Cowper testified to the spiritual aloofness of his day.

Caleb Williams concludes the narrative of his misfortunes, and fixes the blame: "The greatest aggravation of my present lot was, that I was cut off from the friendship of mankind. I can safely affirm, that poverty and hunger, that endless wanderings, that a blasted character and the curses that clung to my name, were all of them slight misfortunes compared to this. I endeavored to sustain myself by the sense of my integrity, but the voice of no man upon earth echoed to the voice of my conscience. 'I called aloud; but there was none to answer; there was none that regarded.' To me the whole world was unhearing as the tempest, and as cold as the torpedo. Sympathy, the magnetic virtue, the hidden essence of our life, was extinct."'1

Near the close of the century, Collins, the amiable youth who may be regarded as a mouthpiece for Godwin's theory, says, "It is more necessary for me to feel compassion for you, than that I should accumulate your misfortune by my censures."'

The spirit of romanticism could not long tolerate such apathy for the masses, and, therefore, by the middle of the century, the new movement had stimulated such compositions as Gray's "short and simple annals of the poor," and Goldsmith's "Deserted Village." Once started, there was no cessation. On this side of the Atlantic it culminated in the dictum, "All men are created equal"; and a little later on the other side, in "A man's a man for a' that."

1. "Caleb Williams," II, Ch. xiv.

2. "Ibld." II, Ch. Xiv. 
Again, the romantic revival is marked by renewed interest in things mediaeval-mediaeval ideals, materials, and literature. "In the eighteenth century, the despised ages of monkery, feudalism, and superstition began to reassert their claims upon the imagination. Ruined castles and abbeys, coats of mail, illuminated missals, manuscript romances, black-letter ballads, old tapestries, and wood carvings acquired a new value. Antiquaries and virtuosos first, and then poets and romancers, reconstructed in turn an image of mediaeval society." 1 By turning to the Middle Ages for inspiration, the romanticists rediscovered and utilized much valuable literary material long since forgot. Haunted castles and monasteries enveloped within an atmosphere of superstition, strangeness, and mystery, and peopled with knights, tyrants, and giants endowed with every form of necromancy-these were some of the materials dug out of the Middle Ages intended to arouse the emotions, and to give free rein to the fancy and to the imagination.

The novel shows a marked tendency to continue throughout th century the vein of realism begun by Richardson and Fielding in the portrayal of contemporary life and manners. But fiction at no time entirely escaped the effect of the romantic movement. There appears at least to be an occasional change of mood even before the middle of the century; soon after, the novel is caught in the current and swept in the direction of romanticism.

Nature-wild and rugged mountain scenery and landscape painting-has a fixed place, afer Walpole, in this new type of fiction. "It is only within a few years," wrote Joseph Wharton, 1782, "that the picturesque scenes of our country, our lakes, mountains, caverns, and castles have been visited and described." Although Mrs. Radcliffe (in 1794) had never seen the mountains that she described so vividly in "The Mysteries of Udolpho," her wonderful imaginative descriptions convince us of the movement which sent man from cities and drawing-rooms to enjoy God's great out-of-doors. She takes care to fix the setting in the very heart of nature:

1. H. A. Beers, "A History of English Romanticism in the Eighteenth Century," p. 90. 
"On the pleasant banks of the Garonne, in the province of Gascony, stood, in the year 1584, the chateau of Monsieur St. Aubert. From its windows were seen the pastoral landscape of Guienne and Gascony stretched along the river, gay with luxuriant woods and vines and plantation of olives. To the south, the view was bounded by the majestic Pyrenees, whose summits, veiled in clouds, or exhibiting awful forms, seen, and lost again as the partial vapors rolled along, were sometimes barren, and gleamed through the blue tinges of air, downward to their base. These tremendous precipices were contrasted by the soft green pastures, and the woods that hung upon their skirts; among whose locks, and herds, the simple cottages, the eye, after having scaled the cliffs above, delighted to repose. To the north, and to the east, the plains of Guienne and Languedoc was bounded by the waters of Biscay."1

Refreshing sketches like the following meet the reader on every page:

"Little woody recesses appeared among the mountains, covered with bright verdure and flowers or a pastoral valley opened its grassy bosom in the shade of the cliffs, with flocks and herds loitering along the banks of a rivulet that refreshed its perpetual green."

Mrs. Radcliffe's landscape paintings are clearly decorative; they are not essential to the whole. She does not succeed in making plot and background blend harmoniously. Too frequent occurrence of similar sketches retards the action greatly. When the reader must visualize such lavish scenery on almost every page, he becomes sensible of the fact that the movement of the plot is losing momentum. Nor is he surprised to find that her pigments are soon diluted with soft emotionalism, an emotionalism which closely resembles mere sentimentalism: Emily, she says, "often looked through her tears upon the grandeur of the Pyrenees. . ." And again, "the scenes through which they now passed were as wild and romantic as any they had yet observed-with this difference, that beauty, every now and then, sof tened the landscape into smiles."'2

Smollett's "Humphrey Clinker" was published in 1771. Matthew Bramble's portrayal of Lock Lomond in this book

1. "The Mysteries of Udolpho," $\mathrm{Ch}$. $\mathrm{i}$.
2. "Ibid." 
is one of the many excellent out-of-doors pictures that adorn the pages of this novel:

"I have seen the Largo di Gari, Albano, De Vico, Bolsena, and Geneva, and, upon my honor, I prefer Lough-Lomond to them all; a preference which is certainly owing to the verdant islands that seem to float upon its surface, affording the most enchanting objects of repose to the excursive view. Nor are the banks destitute of beauties, which even partake of the sublime. On this side they display a sweet variety of woodland, cornfield, and pasture, with several agreeable villas emerging as it were out of the lake, till, at some distance, the prospect terminates in huge mountains covered with heath, which being in the bloom affords a very rich covering of purple. Eeverything here is romantic beyond imagination. .. What say you to a natural basin of pure water, near thirty miles long, and some places nearly seven miles broad, and many above a hundred fathoms deep, having four-andtwenty habitable islands, some of them stocked with deer, and all of them covered with wood; containing immense quantities of delicious fish, salmon, pike, trout, perch, flounders, eels, and powans, the last a delicate kind of fresh water herring peculiar to this lake; and finally, communicating with the sea, by sending off the leaven through which all those species (except the powan), make their exit and entrance occasionally!

"There is an idea of truth, in an agreeable landscape taken from nature, which pleases me more than the gayest fiction which the most luxuriant fancy can display."1

"To return to nature is, in one sense, to find a new expression for emotions which have been repressed by existing conventions."2 Gothic fiction, by transplanting her characters into suitable environments, gave every opportunity for excitation and expression of the deeper feelings. The author of "The Mysteries of Udolpho" would have her readers know that,

"To him who in love of nature holds Communion with her visible forms, she speaks a various language."

1. "Humphrey Clinker," p. 201.

2. Leslie Stephen, "History of English Thought In the Elghteenth Century," p. 447. 
The "still voice" that comes from nature's teachings inspires the mind and touches the emotions:

"The evening gloom of woods was always delightful to me, said St. Aubert, whose mind now experienced the sweet calm which results from the consciousness of having done a beneficent action, and which disposes it to receive pleasure from every surrounding object. I remember that in my youth this gloom used to call forth to my fancy a thousand fairy visions and romantic images; and I own I am not yet wholly insensible to that high enthusiasm which wakes the poet's dream. I can linger with solemn steps, under the deep shades, send forward a transforming eye into the distant obscurity, and listen with thrilling delight to the mystic murmuring of the wnods."1

"The dawn, which softened the scenery with its peculiar gray tint, now dispersed, and Emily watched the progress of the day, first trembling on the tops of the highest cliffs, then touching them with splendid light, while their sides and the vale below were still wrapped in dewy mist. Meanwhile the sullen gray of eastern clonds began to blush, then to redden, and then to glow with a thousand colors, til the golden light darted over all the air, touched the lower points of the mountain's brow, and glanced in long sloping beams upon the valley and its stream. All nature seemed to have awakened from denth into life. The spirit of St. Aubert was renovated. His heart was full; he wept, and his thoughts ascended to the great Creator.

"Emily wished to trip along the turf, so green, and bright with dew, and to taste the full delight of the liberty which the izard seemed to enjoy as he bounded along the brow of the cliffs; while Valancourt often stopped to speals with the travellers; and with social feeling to point out to them the peculiar objects of his admiration. St. Aubert was pleased with him: Here is the real ingeniousness and ardor of youth, said he to himsclf; this young man has never been at Paris."2

"Around, on every side, far as the eye could penetrate, were scen only in forms of grandeur-the long perspective of mountain tops, tinged with the ethereal blue, or white with snow; valleys of ice and forests of gloomy fir. The serenity and clearness of the air in 
these high regions, were particularly delightful to travellers; it seemed to inspire them with a finer spirit, and diffused indiscribable complacency in their minds. They had no words to express the sublime emotions they felt."

"While the distant perspective of the valley was lost in the yellow mist of moon-light, the travellers sat for some time wrapped in the complacency which such scenes inspire.

"These scenes, said Valancourt, at length, soften the heart like the note of sweet music, and inspire that delicious melancholy, which no person, who has felt it once, would resign for the gayest of pleasures. They awaken our best and purest feelings, disposing us to benevolence, pity, and friendship. Those whom I love, I always seem to love more in such an hour as this. His voice trembled and he paused."1

It is evident, of course, that there is very little sincerity in these soliloquies about nature. But Mrs. Radcliffe is a conscious romanticist, or at least she is a conscious reactionary against the city life and drawing-room of London society. "Back to nature" was the cry of romanticism; be "free in God's great out-of-doors" was its motto. Mrs. Radcliffe, a very great enthusiast, did her best, but in her exuberancy she failed to grasp the deeper significance of the movement. Instead of real poetic mountains that breathe inspiration, she creates artificial mountains that breathe unanimating sentimentalism. Her head was in the movement, however, if her soul was not. Her works reveal the author's earnest desire to lead mankind back to genuine appreciation of nature.

The nature movement was manifested in part by a desire for travel. As the revival of life in the springtime after the long dreary winter made "folks longen to goon on pilgrimages," so the revival of romantic springtime after the blighting winters of pseudo-classicism created an insatiable desire to roam "from hill to hill, from rock to rock, craving combinations of new forms." The urban Doctor Johnson said to Boswell in 1763: "Sir, let me tell you, the noblest prospects which a Scotchman ever sees, is the highroad that leads to England"; but Thomas Gray, who traveled through the Scotch Highlands, advised a pilgrimage there at least

1. "The Mysterles of Udolpho," Ch. Iv. 
once each year. No type of literature was better adapted to express this phase of the romantic movement during the reactionary period, than fiction; and none was seized upon more zealously for this purpose than was the Gothic novel. Sending the travelers on a perilous journey over a road infested with robbers and banditti, was the favorite scheme of many authors.

Even though the public highway was romantic, which Dr. Hedges asserts was not the case, Fielding's characters certainly manifested no displeasure at being on the road toward London. But even before "Tom Jones," in "Joseph Andrews," "Fielding enters upon the great epic of the road. .."1 Smollett's Matthew Bramble is a chronic sufferer from the gout. Acting upon the advice of his physician, he takes an extensive tour through England and Scotland.

"The ruggedness of the unfrequented road often obliged the wanderers to alight from their little carriage; but they though themselves amply paid for this inconvenience by the grandeur of the scenes..."2

"Whenever a scene of uncommon magnificence appeared. he (Valancourt) hastened to inform St. Aubert, who, though he was too much tired to walk himself, sometimes made the chaise wait, while Emily went to the neighboring cliff."”

St. Aubert, instead of taking the more direct road, that ran along the foot of the Pyrenees to Languedoc, chose one that, winding over the heights, afforded more extensive views and greater variety of romantic scenery." 4

The travelers in these novels, whether riding or walking, seem to enjoy every foot of the journey: Emily and St. Aubert "travelled leisurely, stopped wherever a scene uncommonly grand appeared; frequently alighted to walk to an eminence whither the mules could not go. . . and of ten sauntering over hillocks covered with wild thyme...."5

"The lower class of people," says Richardson in "Clarissa Harlowe," "are ever aiming at the stupid wonderful." This is but another way of saying that the common people

1. W. L. Cross, "The History of Henry Fielding," 1, p. 318.

2. "The Mysteries of Udolpho," Ch. If.,

3. "Ibld."," Ch,

5.. "Ibld.," Ch to. 
are at heart romantic. It was but natural, therefore, that they should find their rightful place in narrative prose literature when the spirit of romanticism once dominated the thought of the age. With reference to the domestics, Walpole declared that his "rule was nature." Godwin was interested especially in the welfare of the masses. By the close of the century, the nobleness of common men in their humble estate, and the true value of the individual, formed the chief subject of romantic literature.

Mrs. Radcliffe does not overlook the possibilities of this theme. St. Aubert and his daughter Emily spent the night in the simple quarters of a country peasant. The next morning Emily led her father downstairs "to the little parlor in which they had supped the preceding night; there they found a neat breakfast set out, while the host and his daughter waited to bid them good-morrow. 'I envy you this cottage, my good friend, said St. Aubert, as he met them, it is so pleasant, so quit, and so neat. .." "1 Emily remained in the peasant's home for several days. On the eve of her departure, she was inspired by a scene of domestic felicity not unlike that perfect picture of noble poverty in "The Cotter's Saturday Night."

Pope impressed upon his age the thought that, in politics, in law, in society, and in religion, "whatever is, is right." The Augustans, therefore, were not to ask the reason why, or to propose ideal remedies. The imagination was rigidly restrained and prohibited from dipping into the future. "The special task of the eighteenth century had been to order, and to systematize, and to name; its favorite methods had been analysis and generalization. It asked for no new experience. . . The abstract, the typical, the general-these were everywhere exalted at the expense of the imaginative, the specific experience, the vital fact."2

Reaction against this restraint was to picture life in terms of the imagination; the antithesis, to resort to the wildest sort of fancy. Romanticism always approaches the subject through the imagination; hence, when the poets and novelists returned to the Middle Ages for inspiration

1. "The Mysterles of Udolpho," Ch. vil.

. H. A. Beers, "A History of Engllsh Romanticism in the tury," p. 44. (Quoted from Newman's Selections.) 
and for material, it was but the manifestation of a natural impulse in keeping with the changing spirit of the times. "The revival of the supernatural, the most obvious occasion for wonder," says Professor Raleigh, "is the main part of the English Romantic movement, as exhibited in imaginative prose."1

Perhaps the most important single date in the history of romanticism is $\mathbf{1 7 6 5}$, when Bishop Percy published his "Reliques of Ancient English Poetry: Consisting of Old Heroic Ballads, Songs, and Other Pieces of Our English Poets." This collection of ancient English poetry is made up of songs, the traditional ballads, the product of the people, for the people, and by the people at a time when they were homogeneous, before the separation of the lettered and the unlettered classes had taken place. It is impossible to assign exact dates to these songs, for they were seldom if ever reduced to writing till many years after they were composed; but it is certain that their roots strike deep into the ancient world of legend and of myth, and that they abound in the supernatural and the marvellous The work of these popular poets of course has little art; but many of their poems show unmistakably that the authors possessed some knowledge of the uses of mystery and suggestion, for their stanzas of ten imply a whole unuttered tragedy of love, treachery, and murder.

Fiction was not wholly apathetic towards this promising source. To what extent the emotional and creative impulses-the purely subjective-were due to ancient ballads, it is not possible to say; but aside from purely emotional possibilities, the mysterious and supernatural elementsmainly objective-were certainly made use of.

In the Middle Ages ballads were sung to the harp by wandering minstrels. "Monk" Lewis makes Theodore impersonate the minstrels by singing an old ballad to the accompaniment of the guitar. He sings "The Water-King," which, from the third to the twelfth stanza, the author confesses in his Advertisement, is the fragment of an old Danish ballad. Theodore, disguised, enters the monastery and converses thus with the nuns:

1. Walter Ralelgh, "The English Novel," p. 217. 
"You shall now hear how dangerous it is for young women to abandon themselves to their passions, illustrated by the adventure of a damsel who fell suddenly in love with an unknown knight."

"But is the adventure true? inquired the porteress.

'Every word of it. It happened in Denmark. . :"

" 'But before I begin,' said he, 'it is necessary to inform you, ladies, that this same Denmark is terribly infested by sorcerers, witches, and evil spirits. Every element possesses its appropriate demons. . . . The rivers are governed by a fiend called, The WaterKing: his province is to agitate the deep, occasion shipwrecks, and drag the drowning sailors beneath the waves. He wears the appearance of a warrior, and employs himself by luring young virgins into his snare...,"1

The Gothic romanticists were in close accord with the tendency of the times to return to the Age of Chivalry, and in many instances they took over bodily the materials stored up in the mediaeval romances. These materials were used to excite the imagination, and to arouse the emotions of curiosity, wonder, fear, and terror.

The first point of direct contact with the Middle Ages is the avowed time of the action. In his preface to "The Castle of Otranto" (first edition), Walpole tells his readers that the "work was found in the library of an ancient Catholic family in the north of England"; and that "it was printed at Naples in the black letter, in the year 1529." "The principal incidents," he declares, "are such as were believed in the darkest ages of Christianity."2 The period of time selected by Miss Reeve for "The Old English Baron," is the fifteenth century, during the reign of Henry IV. Mrs. Radcliffe informs her readers that it was in $\mathbf{1 5 4 8}$ when the chateau of Monsieur St. Aubert stood on the pleasant banks of the Garonne.

The place of action is nearly always the ancient castle, which, with its Gothic equipment, becomes the hero of the story. It is the old mediaeval castle in which

"Doors creak and window's clap, and night's foul bird, Rocked in the spire, screams loud: the gloomy aisles, hocked hetered and hung 'round with shreds of scutcheons And tattered coat of arms, send back the sound. And tattred coat of arms, send the low vaults, The mansions of the dead."

1. "The Monk," Ch. vill.

1. "The Castle of Otranto." Preface to the First Editlon. 
"The scene," said Walpole, "is undoubtedly laid in some real castle"'; and of course he could have added, "that castle is Strawberry Hill." Edmund has his terrible experiences within the Castle of Lovel. "Monk" Lewis says in his Advertisement, "I have been told the ruins of the castle of Lauenstein . . . may yet be seen upon the borders of Thuringia." Seated at midnight upon the broken ridge of a hill overlooking this castle, Alphonso gives a sketch of this ancient place of abode:

"The castle, which stood full in my sight, formed an object equally awful and picturesque. Its ponderous walls, tinged by the moon with solemn brightness; its old and partly ruined towers, lifting themselves into the clouds, and seeming to frown on the plains around them; its lofty battlements, overgrown with ivy, and its folding gates. . . made me sensible of a sad and reverential horror."'2

"Every feature of the edifice, distinguished by an air of heavy grandeur, appcared successively between the branches of the trees-broad turret, the arched gate-way that led into the courts, the drawbridge, and the dry fosse which surrounded the whole."

An atmosphere of mystery and superstition always pervades the Gothic castles:

"This custom, if you will believe the Baron, she (the Bleeding Nun) still continues. He is fully persuaded, that on the fifth of May of every fifth year, as soon as the clock strikes one, the door of the haunted chamber opens. (Observe that this room has becn shut up for near a century). Then out walks the ghostly nun with her lamp and dagger; she descends the stair-case of the eastern tower, and crosses the great hall. On that night the porter always leaves the gates of the castle open, out of respect to the apparition: not that this is thought by any means necessary, since she could easily whip through the key-hole if she chose it; but merely out of politeness, and to prevent her from making her exit in a way so derogatory to the dignity of her ghostship."4

To create this atmosphere and to excite the emotions of

1. "The Castle of Otranto." Preface to the First Edition.

1. "The Monk," Ch. Iy.

3. "The Mysteries of Udiolpho," Ch. if.

4. "The Monk," Ch. IV. 
curiosity, wonder, and fear, the novelist made use of every conceivable means found in the mediaeval romance; hence the machinery of Gothic fiction is unique and varied. It is full of

"Dreams, maglc terrors, spells of mighty power, Witches and ghosts, who rove at midnight hour."

The dream is frequently used, beginning as far back in English fiction as Smollett. "The Castle of Otranto," the author tells us, "was suggested by a dream." 1 A most ugly and frightful one is given by "Monk" Lewis: Lorenzo, whose heart is aflame for the beautiful Antonia, falls asleep on the pavement of the church and dreams of his love. Antonia, whom he has solicited without success to become his bride, enters the cathedral alone, and approaches the altar. When asked by the friar where the bride-groom is, she beckons Lorenzo to approach. He does so and falls at her feet. She hastens to throw herself into his arms, but before he has time to receive her, an "unknown" rushes between them:

"His form was gigantic; his complexion was swarthy, his eyes fierce and terrible; his mouth breathed out volumes of fire, and on his forehead was written in legible characters, 'Pride! Lust! Inhumanity!'

"Antonia shrieked. The monster clasped her in his arms, and, springing with her upon the altar, tortured her with his odious caresses. - She endeavoured in vain to escape from his embrace. Lorenzo flew to her succor; but ere he had time to reach her, a loud burst of thunder was heard. Instantly the cathedral seemed crumbling to pieces; the monks betook themselves to flight, shrieking fearfully; the lamps were extinguished, the altar sunk down, and in its place appeared an abyss vomiting forth clouds of flame. Uttering a loud and terrible cry, the monster plunged into the gulf, and in his fall attempted to drag Antonia with him. He strove in vain. Animated by supernatural powers, she disengaged herself from his embrace, but her white robes were left in his possession. Instantly a wing of brilliant splendor spread itself from either of Antonia's arms. She darted upwards, and, while ascending, cried to Lorenzo: 'Friend! we shall meet above!'

1. Letter to Rev, Mr. Cole, March 9, 1765. CunnIngham, "Letters of Horace Walpole," IV, p. 328. 
"At the same moment, the roof of the cathedral opened; harmonious voices pealed along the vaults; and the glory into which Antonia was received was composed of rays of such dazzling brightness that Lorenzo was unable to sustain the gaze. His sight failed, and he sunk upon the ground.

"When he awoke, he found himself extended upon the pavement of the church. .."1

"A frightful dream had represented to her (Elvira) Antonia on the verge of a precipice. She saw her trembling on the brink: every moment seemed to threaten her fall, and she heard her exclaim with shrieks: 'Save me, mother, save me! Yet a moment, and it will be too late.' Elvira woke in terror. The vision had made too strong an impression upon her mind to permit her resting till assured of her daughter's safety. She hastily started from her bed, threw on a loose night-gown, and, passing through the closet in which slept the waiting-woman, reached Antonia's chamber just in time to rescue her from the grasp of the ravisher."'2

The spectators are aghast while "the pale sheeted ghost goes by":

According to the physician's order, I swallowed a composing medicine; and as soon as the night shut in, my attendants withdrew and left me to repose.

"That reposed I wooed in vain. The agitation of my bosom chased away sleep. Restless in mind, in spite of the fatigue of my body I continued to toss about from side to side till the clock in a neighbouring steeple struck 'one'. . The door was thrown open violently. A figure entered, and drew near my bed with solemn measured steps. With trembling apprehension I examined this midnight visitor. God Almighty! -It was the bleeding Nun!-it was my lost companion!..."3

In "The Castle of Otranto," Isabella and the stranger search for and find the smooth piece of brass enclosed in one of the stones: "That," said Isabella, "is the lock, which opens with a spring, of which I know the secret." St. Aubert, in "The Mysteries of Udolpho," explains to his daugh-

\footnotetext{
1. "The Monk," Ch. 1.
}

3. "Dold.," Ch. Iv. 
ter the secret door in his chamber. It is a sliding plank which is easily recognized by a remarkable knot in the wood. Caleb Williams escaped from Faulklin's home through a concealed door in his apartment-a door that led to a secret chamber, "which many had probably sought as a refuge."

"Monk" Lewis gives us probably the best instance of the use and belief in the talisman. Ambrosio, who lacked strength of mind sufficient to force the demons to obey him, was greatly encouraged in his wicked design against Antonia, by Matilda, who presented him with a myrtle endowed with supernatural powers:

"Receive this constellated myrtle," said she: "while you bear this in hand, every door will fly open to you. It will procure you access tomorrow night to Antonia's chamber: then breath upon it thrice, pronounce her name, and place it upon her pillow. A deathlike slumber will immediately seize upon her, and deprive her of the power of resisting your attempts. . .

"The Abbot received the talisman with silent gratitude...

"He rejoiced in the fortunate issue of his adventure, and, reflecting upon the virtue of the myrtle, looked upon Antonia as already in his power."1

With the talisman in hand, the human monster, Ambrosio, enters the castle, proceeds to Antonia's sleeping chamber, and then induces sleep by means of its magic:

"No sooner did he touch the door (main entrance) with the silver myrtle, than it flew open, and presented him with free passage. ...

"He reached the door of Antonia's chamber. . . . All was hushed within. The total silence persuaded him that his intended victim was retired to rest, and he ventured to lift up the latch. The door was fastened, and resisted his efforts. But no sooner was it touched by the talisman than the bolt flew back. . . His first intention was to perform the magic ceremony as Matilda had charged him: He breathed thrice upon the silver myrtel, pronounced over it Antonia's name, and laid it upon her pillow. The effects which it had already produced permitted not his doubting its suc-

1. "The Monk," Ch. vil. 
cess in prolonging the slumbers of his devoted mistress. No sooner was the enchantment performed than he considered her to be absolutely in his power..."1

The psychological aspect of this type of novel is interesting and important. "Terror, the author's principal engine, prevents the story from languishing," says Horace Walpole in his preface. ${ }^{2}$ By means of supernatural and mysterious agencies, an atmosphere of terror is created. In the presence of these abnormal stimuli, the characters react in response to the emotions of curiosity, wonder, and fear. This was the creed of every Gothic romanticist, in varying degrees, from "The Castle of Otranto" to "Caleb Williams." The author hoped that the reader of these wild narratives would, by putting himself "en rapport" with the characters, experience a rise of emotions corresponding to that of the actors. By calling his victims to the witness stand, and by permitting them to testify concerning the impression the series of events was making upon them, the author expected the story would arouse the emotion of fear, and make his readers cry a little o'nights. Listen to the testimony of several frightened victims:

When the picture quit its panel, descended to the floor, and marched to the end of the gallery, "Manfred accompanied him at a little distance, full of anxiety and horror." When he beheld his son crushed beneath the ponderous helmet, "the horror of the spectacle and the tremendous phenomenon before him took away the prince's speech." 3

Isabella decided to escape from Manfred by the secret passage:

"An awful silence reigned throughout those subterraneous regions, except, now and then, some blast of wind, that shook the doors she had passed, and which, grating on rusty hinges, were re-echoed through the long labyrinth of darkness. Every murmur struck her with new terror. . " "Every suggestion that horror could inspire rushed into her mind."

"She approached the door that had been opened;

1. "The Monk," ch. vill.

2. "The Castle of Otranto." Preface to the First Edition.
3. "Ibld.," Ch. 1. 
but a sudden gust of wind that met her at the door, extinguished her lamp and left her in total darkness.

"Words cannot paint the horror of the princess's situation."1

When at some distance Alphonso viewed the Lindenberg Castle by moonlight, it "formed an object equally awful and picturesque"; but when he thought of the folding gates, expanding in honor of the visionary inhabitant, it made him "sensible of a sad and reverential horror."2

In another situation, "Monk" Lewis gives the most grewsome scene of all the Gothic writers. Don Raymond, who has had such horrifying experiences with the apparition, is ill at ease and partially demented. He is exerting every effort to induce sleep and quiet when the spectre makes her regular nocturnal visit. Don Raymond lets us into his inmost sanctuary:

"That repose I had woed in vain. The agitation of my bosom chased away sleep. Restless in my mind, in spite of the fatigue of my body, I continued to toss about from side to side till the clock in the neighbouring steeple struck 'one'. As I listened to the mournful hollow sound, and heard it die away in the wind, I felt a sudden chillness spread itself over my body. I shuddered without knowing wherefore; cold dews poured down my forehead, and my hair stood bristling with alarm. Suddenly I heard slow and heavy steps ascending the staircase. By an involuntary movement I started up in my bed, and drew back the curtain. A single rush-light, which glimmered upon the hearth, shed a faint gleam through the apartment, which was hung with tapestry. The door was thrown open with violence. A figure entered, and drew near my bed with solemn measured steps. With trembling apprehension I examined this midnight visitor. God Almighty!-it was the Bleeding Nun!-it was my lost companion! Her face was still veiled, but she no longer held her lamp and dagger. She lifted her veil slowly. What a sight presented itself to my startled eyes! I beheld before me an animated corpse. Her countenance was long and haggard; her cheeks and lips were bloodless; the paleness of death was spread

1. "The Castle of Otranto," Ch. 1 .

2. "The Monk," Ch. 18. 
over her features; and her eye-balls fixed steadfastly upon me, lustreless and hollow.

"I gazed upon the spectre with horror too great to be described. My blood was frozen in my veins. I would have called for aid, but the sound expired ere it could pass my lips. My nerves were bound up in impotence, and I remained in the same attitude inanimate as a statue."1

In his efforts to arouse fear, "Monk" Lewis far surpassed other Gothic authors. Don Raymond, speaking of the appearance of the apparition, says, "Every night was this repeated. Far from growing accustomed to the ghost, every succeeding visit inspired me with greater horror. Her idea pursued me continually, and I became the prey of habitual melancholy."' His series of events, designed to arouse the fear instinct, carry with them what is of very great importance-a series of approximations in which the terrorizing agency repeatedly approaches closer and closer to its victim. This is precisely the theory on which Poe constructed "The Pit and the Pendulum," "The Masque of the Red Death," and "A Descent into the Maelstrom."

But the same criticism applies to all. Walpole claims in his preface that the excitement is constantly renewed. But "excitement," says Professor Beers, "is too strong a word to describe any emotion which 'The Castle of Otranto' is now capable of arousing." 3 The truth is, the emotions of curiosity, wonder, and fear are comparatively weak emotions. They are universal emotions to be sure, but in the adult they cannot be easily aroused, and, even if excited to the highest pitch, rapidly abate; they do not stand the strain, therefore, of a well-knit plot. The fact that the action always takes place under cover of darkness is strong evidence of instability. It takes place almost invariably on some "fatal night." "Nocturnal excursions" usually begin just when "the castle bell announces the hour of midnight." The little child is not so much afraid of what is in the dark; the cause of its fear is the fact that darkness deprives it of

1. "The Monk," Ch. 1v.

2. "Ibld."

3. H. A. Beers, "A History of English Romanticlsm," p. 238. 
the use of vision in its defense. Such precarious situations are now not natural to the adult.

Perhaps William Godwin, near the close of the century, approaches more closely to the real spirit of romanticism in Gothic fiction, than does any of his predecessors. That Godwin was a radical, an extremist in his ideals of social and political reform, cannot be gainsaid; and that he permitted his theories to intrude upon and mar his art, there can be no doubt. But a similar accusation might be brought against every eighteenth-century novelist, though with less weight, because their particular theories of reform were not so far-reaching in their immediate consequences, as were Godwin's. There is actually little of a revolutionary character in his one outstanding novel-a novel that seems to live in spite of its critics. "We conceive no one ever began 'Caleb Williams," says Mr. Hazlitt, "that did not read it through: no one that ever read it could possibly forget it, or speak of it after any length of time but with an impression as if the events and feelings had been personal to himself."1 It is noteworthy, too, that Mr. Hazlitt found but one undesirable feature: "The fault, then, of Mr. Godwin's philosophy, in one word, was too much ambition";2 and with respect to novel writing, he implies that, of the two evils, it is far better to have too much ambition, than too little.

"Romanticism is the stirring of new life, the assertion of the principle of growth." To miss this in "Caleb Williams" is to miss its vital force. The Gothic element is there, but it is scarcely more than the faint glimmer of dying embers. The social and political reform elements are there, too, just as they are expressed in the preface or implied in the body of every eighteenth-century novel. Once more: "The essence of romanticism, in its distinctly human expression, is dissatisfaction, 'aspiration'; and what is aspiration but a keen sense of imperfection and a desire for change?" Caleb, the dissatisfied youth, is straining at the leash with all his power to free himself-not so much from social and political fetters, it seems, as from "self." "Why," he asks,

1. Will lam Hazlitt, "Spirit of the Age," p. 36 .

2. "Ibld." p. 26. 
"should my reflection perpetually center upon myself? self an overweening regard to which has been the source of my errors!"1 Finally, Caleb does not blame wholly either Falkland, or social and political conditions; the failure after all must be traced to its real source, self. But Caleb's desire for change, and the struggle to realize it, is vital, strong, and unconquerable. If the reader enters into full "rapport" with Caleb, he feels unmistakably the longing aspiration of the human soul; hence, but for the enthusiasm which must be lacking in any prose work, he feels the very pulse of the movement. Caleb had drawn a circle premature about self; too late he realized that

"Bliss was it in that dawn to be allve,
But to be young was very Heaven!"

The ingredients of eighteenth-century "Gothic" stories' are strictly mediaeval, if there is any individuality about them at all. But the criticism here is, the authors did not know the Middle Ages; indeed there is good evidence that they cared little about knowing them. Walpole was hardly more than a curioso living within a so-called ancient castle built by his own hands. "Walpole knew little about the Middle Ages and was not in touch with their spirit," says Professor Beers, and adds: "At bottom he was a trifler, a fribbler; and his incurable superficiality, dilettantism, and want of seriousness, made all his real cleverness of no avail when applied to such a subject as "The Castle of Otranto." Miss Reeve admits that her story "is the literal offspring of 'The Castle of Otranto', written upon the same plan." A causual reading of "The Mysteries of Udolpho" will convince the reader that Mrs. Radcliffe was farther removed from the Age of Chivalry than she was from the Pyrenees Mountains. If there ever was a castle on the "pleasant banks of the Garonne," certainly Mrs. Radcliffe had never seen it. And "Monk" Lewis says, "I am told' the Castle of Lowenstein may still be seen." The revival of the Middle

1. "Caleb Williams." The Postseript.

This consclousness of self with interests, and with responsibility for the moral consequences attendant upon the disregard of those interests, is not a new note. Tom Jones uses nlmost the same language: "But why do I blame Fortune? I am myself the cause of all my misers." "Tom Jones," Bk. XVIII, Ch. Ii. 
Ages, therefore, in so far as the Gothic novel was concerned, was almost purely fanciful. The imagination was uncultured because the authors were deficient in knowledge and out of touch with the spirit of those times.

There can be no doubt, however, that this type of fiction was entertaining, and that it was popular, too, in the latter part of the eighteenth century. Walpole declared in his preface that his intention in laying the book before the public at that time was a matter of entertainment. Presently a second edition was called for, and other novels of the same class followed. If we wonder today why it entertained then, we need but to remember that pseudoclassicism had dammed up the emotions, and had rigidly restrained the imagination for three quarters of a century; and that magic, mystery, and chivalry, though artificial, did much toward releasing them. Fear may be excited if the machinery designed for that purpose succeeds in attracting attention; while it does not attract our attention today, it certainly did to a very marked degree in the latter half of the eighteenth century, because men's minds were ripe for it.

The Gothic novel before "Caleb Williams" was always reactionary in tone, and nearly always so in purpose. Its ingredients purported to be from the Age of Chivalry; hence the force was exerted against pseudo-classis canons chiefly by the power of fancy and imagination. The Gothic story, therefore, kept the mind of the masses open and free, and made for the poets a more easily accessible way to the soul.

"Romanticism," says Professor Beers, "is a word which faces in two directions. It is now opposed to realism, as it was once opposed to classicism. As, in one way, its freedom and lawlessness, its love of novelty, experiment, 'strangeness added to beauty,' contrast with the classical respect for rules, models, formulae, precedents, conventions; so, in another way, its discontent with things as they are, its idealism, aspiration, mysticism contrast with the realist's conscientious adherence to fact."1

The Gothic novel differed from the old type of romance,

1. H. A. Beers, "A history of English Romanticism in the Eighteenth Century," p. 23. 
before Richardson and Fielding, in that it was tempered by English life and thought of the eighteenth century. In its effect upon English life, it seems to have been an effectual complement to the School of Realism. Realism helped men and women to know themselves intellectually, socially, and morally by calling to it reason and common sense, based on general principles. ${ }^{1}$ Romanticism added a new charm to life by affecting that life through the imagination. ${ }^{2}$

"The attitude of the age towards the marvellous," Professor Raleigh points out, "has been best expressed, as might be expected, by the great exponent of the age, Dr. Samuel Johnson. 'To select a singular event, and swell it to a giant's bulk by fabulous appendages of spectres and predictions has little dinicuily; for he that forsakes the probable may always find the marvelous. And it has little use; we are affected only as we believe; we are improved only as we find something to be imitated or declined. I do not sce that 'The Bard' promotes any truth, moral or political."3

"We are affected only as we believe'." This sentence Professor Raleigh selects for comment: 'The sentence gives a terse and final statement of the chief eighteenth-century heresy ... It is the key to the dominant methods in the art of fiction. But the statement is not true, for we are affected also as we imagine. And his recognition of this long-forgotten truth entitles Horace Walpole, who hit upon it in blundering dilettante fashion, and illustrated it in his 'Castle of Otranto,' to a high place among the founders of modern Romanticism."'4

But, "whatever the origin," says Leslie Stephen, "the instinct gratified by the novels, and the condition of the time,

1. "Reason," says Sterne, "is, half of it, Sense: and the measure of Heaven itself is but the measure of our present appetites and concoctions."-"Tris-

2. "The Imagination," Chy . Xfil. cation. It has a flute which sets the atoms of our frame in a dance, like planets; and, once so liberated, the whole man is reeling drunk to the music, they never quite subside to their old stony state."

"Rut what is the Imaginatlon?" he aslks. His answer is: "Only an arm or weanon of the interior energy; only the precursor of the reason. And hooks that treat the old pedantries of the world, nur times, places, professlons, customs, opinlons, histories, with a ccrtain freedom, and distribute things, not niter the usnge of America and Europe, but after the laws of right reason, and with as daring a frcedom ns we use in dreams put us on our fect agajn, enable us to form an original judgment of our duties, and suggest new thoughts for tomorrow."-Ralph Waldo Emerson, "Soclety and Solitude," 'Books," pp. 303-304.

3. Johnson's Works, VI, p. 224.

4. Walter Raleigh, "The English Novel," pp. 220-221. 
sufficiently determined the form. The world of legend and ideal grandeur had grown dim. ${ }^{1}$ A new social form was developing itself. What could men do more than talk about themselves? And thus, since the days of Defoe, we have derived unceasing amusement from looking into the mirrors which reflect, with more or less fidelity, the incidents and manners of our daily life."2

"What could men do more than talk about themselves?" -a sentence pregnant with meaning and significance for the mid-eighteenth century. Richardson wrote in "Clarissa Harlowe:" "Great sentiments uttered with dignity by a good person, give, as it were, a visibility to the soul." That great sentiments were uttered through the novel by characters chosen from "all" ranks of English society, is certain; that those sentiments did give visibility to the soul-."individuality" to the common Englishman-there can be no doubt.

"In the period of our history in question (1740-1760), a security of person and property, and a freedom of opinion had been established, which made every man feel of some consequence to himself, and appear an object of some curiosity to his neighbors; our manners became more domesticated; there was a general spirit of sturdiness and independence, which made the English character more truly English than perhaps at any other period-that is, more tenacious of its own opinions and purposes."

"Fielding succeeded in turning men's thoughts upon themselves," says his biographer, Professor Cross. The immediate and direct result of this was the realization of self-the individualization of common men. The next logical step was dissatisfaction with self and with the conditions of life then existing. By calling again the imagination into play through the romantic story, the masses began reaching out, though perhaps unconsciously, for better things-for more ideal conditions of life. By the close of the century, they were seeking to embody known ideals through the novel of theory.

1. Referring to the old romance before Richardson and Fielding.

2. Leslfe Stcphen, "English Thought in the Elghteenth Century!" I, p. 379. 


\section{CHAPTER VI}

\section{THE DEMOCRATIC IDEA}

When artists like Richardson, Fielding, Sterne, and Goldsmith made common men leading characters in their novels, they were unconsciously advancing the theory of equality, and were teaching the masses, and their social superiors likewise, that all men of whatever rank in society had a right to full representation in the pages of fiction. Once in, they could not be denied the right of free thought and speech on all matters both public and private. If he was true to human nature as he claimed to be in his preface, the writer was bound literally to respect the rights of common men. Professor Stoddard calls attention to the fact that Jefferson, as author of the Declaration of Independence, was the first to assert in an utterance of great importance "the notion of individual worth, the dignity of man as man," and he adds: "Yet no less significantly, if less dogmatically, did Fielding assert the same proposition when, twenty-seven years before the Declaration of Independence was penned, he made the world take eager interest in one common-place individual, Tom Jones. It is an assertion of the rights of man when Sterne compels us to care for Uncle Toby and for Tristram Shandy; when Richardson makes the woes of Pamela move the hearts of a generation; when Smollett finds nobility of character in a Roderick Random or a Humphrey Clinker; when Goldsmith paints a universal type in the unfortunate Vicar of Wakefield."1

The idea of religious, social, and political equality-the notion that all men are created equal-was slowly changing English life and thought throughout the latter half of the eighteenth century. "The novel is the epic of democracy," says Professor Stoddard, and adds: "It is no accident that the great days of the historical novel followed the great days of strife for liberty in America and France."2 But of

1. F. H. Stoddard, "The Evolution of the English Novel," pp. $80-91$.

2. "Iibld.," p. 02 . 
course the struggle for liberty here and in Europe was not limited to a few years of actual fighting; men's minds had to be prepared for the times that were to try their souls. The novel, especially that of Richardson, Fielding, Sterne, and Goldsmith, did much towards this end.

Before average men can grasp the idea of democracyequality of person and opportunity-it is necessary for them to have a fairly clear conception of personal identity-an idea of the individuality of persons. This was the first great task of the novelist. "The notion of personality," says Professor Stoddard, "is implied in the very idea of the novel."1 Professor Cross asserts that "Fielding succeeded in turning men's thoughts upon themselves." This was the first step in the process of individualization-the first step in making the average man feel the "scope and sovereignty of his ego."

One thing of very great importance-one that marked a step in advance for the masses-was the fact that people of rank-kings, lords, princes, nobles-were displaced in the novel often by people of obscure parentage, and little affluence. "Untitled humanity" now hecame the accepted subject for romance. Their number and character for so early a date are astonishing. Pamela, the first to appear, was a poor girl. Born in the county of obscure parents, she was happy in the servcie of Mr. B.'s mother, and apparently would have been contented to continue in the service of lady Booby; and simple, innocent Parson Adams declared that no man was too common or too poor for him to notice and to consider his equal. The accomplished Clarissa Harlowe was from the middle class, possibly but a station in advance of Pamela. Both Tom Jones and Sophia Western had been bred in the country, and neither possessed any knowledge of the city. Amelia, Tristram Shandy, Humphrey Clinker, and a host of others seem now to have acquired a natural right in the pages of fiction. "The individual, no matter of what degree," says Professor Stoddard, "now had rights of representation in the novel no less than in government. . . It is the declaration of independence in fiction, and ends for-

1. F. H. Stoddard, "The Evolution of the English Novel," pp. 45-46. 
ever the exclusive domination of the mediaeval romance."1

To effect this change from titled to untitled humanity, novelists made use of several means. Richardson, in defending the slow epistolary method of telling the story, does so partly on the ground that it has advantages in revealing personality. "The letters and conversations, where the story makes the slowest progress," he says, " are presumed to be 'characteristic.' They give occasion, likewise, to suggest many interesting 'personalities,' in which a good deal of the instruction essential to a work of this nature is conveyed."' One thing that made personality so conspicuous and interesting was that novelists usually pitted the wit and judgment of men and women of low birth-possessors of little culture and few desirable attainments-against those fine qualities and parts of their social and intellectual superiors. And in this combat of wits, the person of average culture and ability nearly always won his point. Authors saw to it, too, that those who assumed greater excellencies for themselves frankly confessed inferiority in this particular.

Richardson's first novel, which ran its course downward through the masses, is full of instances that elevate Pamela above her superior, Mr. B. The young girl, just fifteen years of age, writes a letter to her poor but honest parents in which she reports a conversation between Mr. B. and Longman:

"As for the rest, said he (Mr. B.), the girl is a good sort of body, take her all together; though I must needs say, a little pert, since my mother's death. in her answers, and gives me two words for one; which I can't bear; nor is there reason I should, you know, Longman.

"Did he not, mv dear father and mother deserve all the truth to be told? Yet I overcame myself so far, as to say, Well, your honor may play unon a poor girl, that you know 'can' answer you, but 'dares' not."

"You do well, sir, said I, to even your wit to such a poor maiden as me: but, permit me to say, that if you

1. F. H. Stoddard. "The Frolution of the Engllsh Novel," p. 91.

3. "Postscript to "Clarissa Harlowe."

"Pamela," I, Letter xxvili, 
was not rich and great, and I poor and little, you would not insult me thus.-Let me ask you, sir, if you think this becomes your fine clothes and master's station? Why so serious, my pretty Pamela? said he: Why so grave? And would kiss me; but my heart was full, and I said, Let me alone; I 'will' tell you, if you was a king, and insulted me as you have done, that you have forgotten to act like a gentleman: and I won't stay to be used thus. . . and I'd have you know, sir, that I can stoop to the ordinariest work of your scullins, for all these nasty soft hands, sooner than bear such ungentlemanly imputations."1

"If I was your equal, sir, said I, I should say this is a very provoking way of jeering at the misfortunes you have brough upon me.

"Oh, said he, the liberties you have taken with my character in your letters, sets us upon a par, at least in that respect. Sir, I could not have taken those liberties, if you had not given me the cause: and the 'cause,' sir, you know, is before the effect.

"True, Pamela, said he; you chop logic very prettily. What the deuce do we men go to school for? If our wits were equal to woman's, we might spare much time and pains in our education: for nature teaches your sex, what, in a long course of labor and study, ours can hardly attain to.-But, indeed, every lady is not a Pamela."

'Pray, Mrs. Jewkes, said I, don't 'madam' me so: I am but a silly poor girl, set up by the gambol of fortune, for a Maygame; ... And let you and me talk upon a foot together; for I am a servant inferior to you, and so much the more as I am turned out of the place.

"Ay, ay, says she, I understand something of the matter; you have so great power over my master, that you may soon be mistress of us all; and so I would oblige you, if I could. And I must and will call you madam; for I am instructed to show you all respect, I'll assure you."'2

Not only is there an air of independence in the conversations of inferiors, but there is also manifested the air of indifference-sometimes a feeling of positive disdain towards superiors:

“ 'Do as I bid you,' says my lady, 'and don't shock

1. "Pamela" I, Letter xxvll.
2. "Ibld", I, Letter xxxul. 
my ears with your beastly language.' 'Marry come up,' cries Slipslop, 'people's ears are sometimes the nicest part about them.'

"The lady, who begun to admire the new style in which her waiting-gentlewoman delivered herself, and by the conclusion of her speech suspected somewhat of the truth, called her back, and desired to know what she meant by the extraordinary freedom in which she thought proper to indulge her tongue. 'Freedom!' says Slipslop; 'I don't know what you call freedom, madam; servants have tongues as well as their mistresses.' 'Yes, and saucy ones too,' answered the lady, 'but I assure you I shall bear no such impertinence.' 'Impertinence! I don't know that I am impertinent,' says Slipslop. 'Y'es, indeed you are,' cries my lady, 'and, unless you mind your manners, this house is no place for you.' 'Manners!' cries Slipslop; 'I never was thought to want manners or modesty neither; and for places, there are more places than one; and I know what I know.' 'What do you know, mistress?' answered the lady. 'I am not obliged to tell that to everybody,' says slipslop, 'any more than I am obliged to keep it a secret.' 'I desire you will provide yourself,' answered the lady. 'With all my heart,' replied the waiting-gentlewoman, and so departed in a passion, and slammed the door after her."1

Again, servants sometimes make positive assertions that no real distinction exists between them and their masters and mistresses. Mr. Tow-wouse and the servant Betty, having been discovered in an act of indecency, are subjected to a severe tongue-lashing by Mrs. Tow-wouse.

Mrs. Tow-wouse to her husband and Betty:

" 'To abuse my bed, my own bed, with my own servant! but I'll maul the slut: I'll tear her nasty eyes out! Was ever such a pitiful dog to take up with such a mean trollop? If she had been a gentlewoman like myself, it had been some excuse; but a beggarly, saucy, dirty servant-maid. Get you out of my house, you whore.' To which she added another name, which we do not care to stain our paper with. It was a monosyllable beginning with a b-, and indeed was the same as if she had pronounced the words, she-dog. Which term we shall, to avoid offence, use on this occasion,

\footnotetext{
1. "Joseph Andrews," I, Ch. Ix.
} 
though indeed both the mistress and maid uttered the above-mentioned $b-$, a word extremely disgustful to females of the lower sort. Betty had borne all hitherto with patience, and had uttered only lamentations; but the last appellation stung her to the quick. 'I am a woman as well as yourself,' she roared out, 'and no shedog; and if I have been no better than I should be, cried she sobbing, 'that's no reason you should call me out of my name; my be-betters are wo-worse than me." "1

Although Pamela and her brother Joseph were born of poor, obscure parents, they were finally admitted on a plane of equality, after much violent protest, into the homes of persons who thought themselves their superiors. Mr. B., apprehensive of the outcome of his marriage to Pamela, tells her frankly what she may expect, and why:

"But what can I do? Consider the pride of my position. I cannot endure the though of marriage, even with a person of equal or superior degree to myself; and have declined several proposals of that kind. How then, with the distance between us in the world's judgment, can I think of making you my wife?-Yet I must have you; I cannot bear the thoughts of another supplanting me in your affections...."

"But yet you see the plea, my girl, which I made to you before, of the pride of condition, and the world's censure, which, I own, sticks a little too close with me still: for woman shines not forth to the public as man; and the world sees not your excellencies and perfections: If it did, I should entirely stand acquitted by the severest censures. But it will be taken in the lump; that here is Mr. B-, with such and such an estate, has married his mother's waiting-maid: not considering there is not a lady in the kingdom that can out-do her, or better support the condition to which she will be raised, if I should marry her. And, said he, putting his arm around me, and again kissing me, I pity my dear girl too, for 'her' part in this censure; for here will she have to combat the pride and sleights of the neighboring gentry all around us. Sister Davers, you see, will never be reconciled to you; and you will, with a merit superior to them all, be treated as if unworthy of their notice."2 
Already Lady Davers had given him a large piece of her mind on this subject:

"Either you will have her for a kept mistress, or a wife," she wrote. "If the former, there are enough to be had without ruining a poor wench that my mother loved. . As to the 'other,' I daresay you don't think of it; but if you 'should,' you would be utterly inexcusable. Consider, brother, that ours is no upstart family; but is as ancient as the best in the kingdom! and, for several hundreds of years, it has never been known, that the heirs of it have disgraced themselves by unequal matches."'

Later when informed by Pamela that she and Mr. E. were married, Lady Davers characterised her with such epithets as "painted dirt," "baby-face," "waiting-maid," "beggar's-brat," and "beggar-born." When convinced that he had actually married his mother's waiting-maid, the proud Lady Davers committed her brother, body and soul, to mother earth: "I thought you a gentleman once, and prided myself in my brother," she cried; "but I'll say now with the burial service, "Ashes to ashes, and dirt to dirt." "

But Lady Davers's warnings and fits of anger did not deter her brother from marrying his mother's servant, and from making her his equal in social life. Moreover, Pamela had a brother whom Fielding named Joseph; and this same Joseph, Lady Booby importuned Adams not to "mister" to her. $^{2}$ But when her nephew, Spuire Booby, made Pamela his wife and brought her to live with them, he demanded of his aunt that Joseph be admitted into the family circle, an equal in all respects:

"They were now arriving at Lady Booby's, and the squire, desiring them to wait a moment in the court, walked in to his aunt, and called her out from his wife, acquainted her with Joseph's arrival, saying, 'Madam, as I have married a virtuous and worthy woman, I am resolved to own her relations, and show them all a proper respect; I shall think myself therefore infinitely obliged to all mine who will do the same. It is true, her brother hath been your servant, but he is

1. "Pamela," Letter xxl1.

2. "Jomeph Andrews," Bl. IV, Ch. 11. 
now become my brother; and I have one happiness, that neither his character, his behaviour, or appearance, give me any reason to be ashamed of calling him so. In short, he is now below, dressed like a gentleman, in which light $I$ intend he shall hereafter be seen; and you will oblige me beyond expression if you will admit him to be of our party..."

Soon afterwards he says: "My love to my dear Pamela, brother, will extend to all her relations; nor shall I show them less respect than if I had married into the family of a duke."

Fielding, like Richardson, loved to give little curtain lectures and set dissertations for the perusal of his readers. In one of these he boldly asserts that there is no fundamental difference between men of so-called "high," and those of "low" degree. He discovered, as did Sterne later, that "human nature is the same in all professions." But there were those who took great delight in describing themselves as "high people" in contradistinction to "low people." Those who thought of themselves more highly than they deserved, he ridiculed as hypocrites; at the same time he informed men of low birth that they had been allowing themselves to be deceived by distinctions that were only apparentdistinctions that were in no sense real and vital. His words are clear and forcible:

"These are pictures which must be, I believe, known: I declare they are taken from life, and not intended to exceed it. By those high people, therefore, whom I have described, I mean a set of wretches who, while they are a disgrace to their ancestors, whose honor and fortunes they inherit (or perhaps a greater to their mother, for such degeneracy is scarce credible), have the insolence to treat those with disregard who are at least equal to the founders of their own splendor. It is, I fancy, impossible to conceive a spectacle more worthy of our indignation than that of a fellow, who is not only a blot in the escutcheon of a great family, but a scandal to the human species, maintaining a supercilious behaviour to men who are 
an honor to their nature and a disgrace to their fortune."1

In his "Dissertation Concerning High People and Low People," he explains more freely what he means:

"Be it known then, that the human species are divided into two sorts of people, to wit, high people and low people. As by high people I would not be understood to mean persons literally born higher in their dimensions than the rest of the species, nor metaphorically those of exalted characters or the reverse. High people signify no other than people of fashion, and low people those of no fashion. Now, this word fashion hath by long use lost its original meaning, from which at present it gives us a very different idea; for I am deceived if by persons of fashions we do not generally include a conception of birth and accomplishments superior to the herd of mankind; whereas, in reality, nothing more was originally meant by a person of fashion than a person who dressed himself in the fashion of the times; and the world really and truly signifies no more at this day. Now, the world being. divided into people of fashion and of no fashion, a fierce contention arose between them; nor would those of one party, to avoid suspicion, be seen publicly to speak to those of the other, though they often held a very good correspondence in private. In this contention it is difficult to say which party succeeded: for, whilst the people of fashion seized several places to their own use, such as courts, assemblies, operas, balls, etc., the people of no fashion, besides one royal place, called his Majesty's Bear-garden, have been agreed to be divided between them, namely, the church and the playhouse, where they segregate themselves from each other in remarkable manner; for, as the people of fashion exalt themselves at church over the heads of the people of no fashion, so in the playhouse they abase themselves in the same degree under their feet. This distincton I have never met with any one able to account for; it is sufficient that, so far from looking on each other as brethren in the Christian language, they seem scarce to regard each other as of the same species. This, the terms 'strange persons, people one does not know, the creature, wretches, beasts, brutes,' and many other appelations evidently demonstrate; which Mrs.

1. "Joseph Andrews," Bk, III, Ch, $\mathrm{l}$. 
Slipslop, having often heard her mistress use, thought she had also a right to use in her turn; and perhaps she was not mistaken; for these two parties, especially those bordering nearly on each other, to wit, the lowest of the high, and the highest of the low, of ten change their parties according to place and time; for those who are people of fashion in one place are of ten people of no fashion in another. And with regard to time, it may not be unpleasant to survey the picture of dependence like a kind of ladder; as, for instance: early in the morning arises the postilion, or some other boy, which great families, no more than great ships, are without, and falls to brushing the clothes and cleaning the shoes of John the footman, who, being dressed himself, applies his hands to the same labors for Mr. Second-hand, the Squire's gentleman; the gentleman in the like manner, a little later in the day, attends the squire; the squire is no sooner equipped than he attends the levee of my lord, which is no sooner over than my lord himself is seen at the levee of the favorite, who, after the hour of homage is at an end, appears himself to pay homage to the levee of his sovereign. Nor is there, perhaps, in this whole ladder of dependence, any one step at a greater distance from the other than the first from the second; so that to a philosopher the question might only seem, whether you would choose to be a great man at six in the morning, or at two in the afternoon. And yet there are scarce two of these who do not think the least familiarity with the persons below them a condescension, and, if they were to go one step farther, a degredation."1

The effect of such heart-to-heart talks upon the mind of the masses must have been considerable. Here in an interesting story readers met real, live men and women like themselves-a new thing to them. They listened to these people give utterance to thought, which, if they themselves had not yet dared to utter, reminded them that they might now do so if they chose. They were made aware that new possibilities and new opportunities were theirs, if they set about it in earnest to realize them.

Writing of "Pamela," Professor Dobson says: "As the Slough incident shows, it appealed to the humbler reader as well as to the person of quality; it bridged over the then

1. "Joseph Andrews," Bl. II, Ch. xlll. 
more widely trenched breach between rich and poor; for who could say that a servant-girl who played her cards as cleverly as Pamela Andrews might not obtain a like reward?"1

Whether or not Mr. B. took the servant-girl to wife (as her author claimed) because of the "transcendent excellencies" and "the awful heights of virtue" ascribed to her, we may assume made little difference to the masses of readers. Pamela, with whom they identified themselves, had won a "husband" from social ranks far above hers. This was to them the simple truth of the whole matter. No wonder the swarthy blacksmith rang the churchbell at Slough in honor of the glorious victory. What it meant to common people -those weeds that grow "in the common garden of creation," as Lady Booby's "superior mind" conceived them to be-can hardly be overestimated.

Fielding eagerly seized the opportunity to ridicule $\mathrm{Pa}$ mela's feigned virtue-a task not difficult for him to succeed in; but he did not ridicule the fact of her marrying $\mathrm{Mr}$. B. Not only does Fielding allow Squire Booby to bring Pamela home to wife, but he writes a dissertation to boot, wherein he exposes feigned differences that have long divided the human species into "two sorts of people." Undoubtedly Fielding regarded this union as proper and correct, and hence found no sufficient reason for ridiculing it. "I defy the wisest man in the world," he says, speaking through Joseph Andrews, "to turn a true good action into ridicule." And if more evidence should be desired to convince one of his sincerity in this matter, he would need only to be reminded that for his second wife Fielding himself married a young woman who was much below him socially-"his own cook-wench," Smollett called her. The union was defended, too, by ladies of high standing, such, for example, as Lady Mary Wortley Montague and Lady Louisa Stuart.2

Thus in the new kind of writing, destined soon to become widely known, the common people discovered two great authors who were championing their cause for social equality. But they were not satisfied with the more favorable

1. Austin Dobson, "Samucl Richardson," p. 39.

2. W. L. Cross, "The Hlstory of Henry' Ffelding," II, Dp. 61-69, 
outlook for equality and justice that these authors held out to them; the Englishman's mind is really never satisfied.

Professor Burton defines the modern novel as "a study of contemporary society with an implied sympathetic interest, and, it may be added, with special reference to love as a motor force, simply because love it is which binds together human beings in their social relations." 1 The democratic tone of this definition makes it no less applicable to most eighteenth-century novels.

As one reads the novels of Richardson, especially the first which Lady Mary declared was "the joy of chambermaids of all nations," and compares the subject of this novel with that of the old romance, he is struck forcibly by the love factor in the Pamela story. It is hardly too much to say that love was the greatest single force in the process of leveling what hitherto had been social barriers. It is true that Richardson, speaking through Mr. B., greatly exagerated Pamela's virtue; but then love is blind, so why criticise Mr. B. when he declares, even against his will, "you have too much wit and good sense not to discover (Pamela) that $\mathrm{I}$, in spite of my heart and all my pride of it, cannot but love you. Yes, look up to me, my sweet-faced girl! I 'must' say I love you...."2

Mr. B. may have been disillusioned later-we leave that to him and to the gods-but we can be absolutely certain, however, that he has been captivated by the wit, the good sense, and the integrity of character, which are characteristics of his mother's servant. As for Pamela, there is evidence, and plenty of it, that she was dissembling for a prize, and that prize a wealthy husband who was socially and politically distinguished. Persons of quality, wedded to social customs and conventions in the middle of the eighteenth century, could not permit such an infraction without protest from the elite; but of what significance was it? and what did their protest avail? When we carefully analyze the motives back of this union, how far do they fall short of "human nature?" This, after all, was what Richardson and every other writer of the new fiction claimed to present.

1. Richard Burton, "Masters of the Engllsh Novel," p. 10.

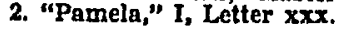


Why should a waiting-maid be denied marriage to advantage, if love was at bottom the motivating force? But if she married for expediency only, ruling love out of the case, then of course she is the personification of deceit, and is not worthy of our consideration. Did Richardson exaggerate the motive, or warp human nature in this particular? He did neither; for this story does put love uppermost. Follow but a few of the many positive assertions, and the sentiment expressed must be convincing:

On Monday Pamela wrote in her Journal:

"This letter, when I expected some new plot, has affected me more than anything of 'that' sort could have done. For here is plainly his great value for me confessed, and his rigorous behaviour accounted for in such a manner, as tortures me much. All this wicked gypsy story is, as it seems, a forgery upon us both, and has quite ruined me: For, oh my dear parents, forgive me! but I found, to my grief, before, that my heart was too partial in his favour; but 'now' with so much openness, so much affection; nay, so much 'honour' too (which was all I had before doubted. and kept me on the reserve), I am quite overcome. This was a happiness, however, I had no reason to expect. But, to be sure, I must own to you, that I shall never be able to think of anybody in the world but him.-Presumption! you will say; and so it is: But love is not a voluntary thing: 'Love,' did I say?-But come, I hope not:At least it is not, I hope, gone so far as to make me 'very' uneasy: For I know not 'how' it came, nor 'when' it began; but crept it has, like a thief, upon me; and before I knew what was the matter, it looked like love.

"Oh my treacherous, treacherous heart! to serve me thus! and give no notice to me of the mischief thou wast about to bring upon me!-But thus foolish to give thyself up to the proud invader, without ever consulting thy poor mistress in the least! But thy punishment will be the 'first' and the 'greatest'; and well deservest thou to smart, oh perfidious traitor! for giving up so weakly thy whole self, before a summons came; and to one, too, who had used me so hardly; and when, likewise thou hadst so well maintained thy post against 
the most violent and avowed, and, therefore, as I thought, more dangerous attacks."1

Mr. B., whose "manner", says Pamela, "had something so noble and so sincere," declares over and over again that love has superseded the baser passions, and has become the motivating and regulating force of his behavior towards Pamela. He requests her to "invite" him into her presence:

"I will only say one thing, that if you will give me leave to attend you at the Hall (consider who it is that requests this from you as a 'favour'), I solemnly declare, that you will have cause to be pleased with the obliging remark of your confidence in me, and consideration for me; and if I find Mrs. Jewkes has not behaved to you with the respect due to one I so dearly love, I will put it entirely into your power to discharge her the house, if you think proper. . . Dearest Pamela, answer favourably this earnest request of one who cannot live without you, and on whose honour to you, you may absolutely depend...."1

Later, she says, "he was pleased to add another charming reflection, which showed me the noble sinverity of his kind profession. I do own to you, my Pamela, said he, that I love you with a purer flame than ever I knew in my whole life; a flame to which I was a stranger. .. And I know more sincere joy and satisfaction in this sweet hour's conversation with you, than all the guilty tumults of my former passion ever did, or (had even my attempts succeeded) ever could have afforded me."

Such were the sentiments divulged by social unequals some years before the middle of the eighteenth century. "Richardson's novel (Pamela), says Professor Cross, "ran

1. "Pamela," I, Letter xxxil.

Fielding was not content to introduce natural and unaffected love scencs in his great novel; but was inclined to preach agninst the lack of genuine affections in persons of quality and amuence. When Sophia and her lover discovered each other in Isdy Bellaston's parlor, Sophla gave "a violent scream, and scarce preserved herself from fainting till Jones was able to move to her and support her in his arms."

"To paint the looks or thoughts of either of these lovers," he declares. "Is beyond my power. As their sensations, from their mutual sllence, may be
judged to have been too big for their own utterance, it cannot be supjudged to have been too big for their own utterance, it cannot be supfew of my readers have been enough in love to feel by their own hearts what passed at this time in theirs."-"Tom Jones," Bk. XIII, Ch. $x i$. Again he says: "I am convinced there never was less of love intrigue carrled on among persons of condition than now. Our present women have been taugh by their mothers to $n x$ thelr thoughts only on ambltion and vanity, and to dispise the pleasure of love as unworthy their regard. . ""Tom Jones," Bk, XIV, Ch. 1 . 
its course down through all classes to the servant's hall. .."1 There is no mistaking its wide and effective influence.

"Both the impatient self-assertion of the middle class, and its quiet settling down into censervative grooves of feeling, are thus foreshadowed. The story of Pamela is an illustration of the Christian equality of souls, quite in keeping with the wide-spread modern tendency to exalt a sentimental, theoretical democracy; it breathes, on the other hand, an involuntary subservience to the intrinsic dignity of rank and riches. .."2

Closely allied to the love factor as a motor force in furthering democratic ideas, was the question at issue regarding the choice of a husband. The convictions of despotic parents aid willful danghters differed widely on this important matter-a matter of grave difference, Fielding says, that was much too common. Richardson and Fielding make much of this, and seem to have succeeded in instituting reforms.

In "Clarissa Harlowe," the author is clear and emphatic: Clarissa refuses to yield to the autocratic will of her father, mother, family, and friends in the matter of choosing a husband for herself. Her so-called stubbornness, independence, and self-will bring down upon her the condemnation of her family. Her brother James writes to her:

"The liberty of 'refusing' (Solme's advances), pretty Miss, is denied you, because we are all sensible that the liberty of 'choosing,' to everyone's dislike must follow...

"This is the light in which the whole debate ought to be taken, Blush, then, Delicacy, that cannot bear the poet's 'amor omnibus idem!' Blush, then, Purity! Be ashamed, Virgin Modesty! And if capable of conviction, surrender your whole will to the will of the honoured pair to whom you owe your being: and beg of your friends to forgive and forget the part you have of late acted."3

"Independence" of action Clarissa later explains in full to Miss Howe: ‘. . . after I bẻcame 'independent,' as I may call it (by which I mean no more than to have the liberty of refusing for my husband a man whom it hurts me but

1. W. L. Cross, "The History of Henry Fielding," I, p. 355.

2. "Cambridge History of Modern Liternture." $\mathrm{X}, \mathrm{p}, 15$.

3. "Clarissa Harlowe," II, Letter $x$. 
to think of in that light); and such as his not visiting me but by my leave...."1 Howe:

Clarissa reports a conversation with her aunt to Miss

"What a hard case is mine!- . . How often, my dearest aunt, must I repeat the same thing?-Let me but be single. -Cannot I live single?-Let me be sent, as I have proposed, to Scotland, to Florence, anywhere: let me be sent a slave to the Indies, anywhere-any of these I will consent to. But I cannot, 'cannot' think of giving my vows to a man I cannot endure!-_"2

Later she writes:

"Only one thing must be allowed for me; that whatever course I shall be 'permitted' or be 'forced' to steer, I must be considered as a person out of her own direction. Tost to and fro by the high winds of passionate control (and, as I think, unseasonable severity), I behold the desired port, the 'single state,' into which I would fain steer; but I am kept off by the foaming billows of a brother's and sister's envy, and the raging winds of a supposed invaded authority; ...."s

Miss Howe is convinced that Clarissa has done all that reason and justice can demand, when she offers to remain single all her life; she writes: "The tyrant word AUTHORITY, as they use it, can be the only objection against this offer."'4

Just as Harlowe had determined to join his daughter's inheritance with Solme's fortune regardless of Clarissa's wishes, so Western looked forward to the near future when his own and Allworthy's estate would be joined by the union of his daughter, Sophia, and Blifel. But Tom Jones had already won Sophia's heart-which made a difference to her.

This tyrannical attitude of parents towards prospective matches for their daughters is forcibly expressed by $\mathrm{Mr}$. Western, who, upon being informed by Mrs. Western that his daughter Sophia is in love, cries in a passion: "How! in love! ... in love, without acquainting me! I'll disin-

1. "Clarissa Harlowe, Letter xili.

2. "Ibid.", Letter IIf.

3. "Ibid.," Letter xxvil 
herit her; I'll turn her out of doors, stark naked, without a farthing. Is all my kindness vor'ur and vondness o'ur come to this, to fall in love without asking me leave?' 'But you will not', answered Mrs. Western, 'turn this daughter whom you love better than your own soul, out of doors, before you know whether you shall approve her choice. Suppose she should have fixed on the very person whom you yourself wish, I hope you would not be angry then?' 'No, no,' cries Western, 'that would make a difference. If she marries the man I would ha' her, she may love whom she pleases; I shan't trouble my head about that." "1

Western is changed instantly from rage to complacency when he construed Sophia's reply to be acquiescence in his whole soul was wrapt in hers; that her consent (for so he construed the words, 'you know, sir, I must not, nor can refuse to obey any absolute command of yours') had made him the happiest of mankind."2

Concerning this episode in the life of Western, Felding adds his own criticism: "Instances of this behavour in parents are so common that the reader, I doubt not, will be very little astonished at the whole conduct of Mr. Western. If he should, I own I am not able to account for it; since that he loved his daughter most tenderly, is, I think, beyond dispute. So indeed have many others who have rendered their children most completely miserable by the same conduct; which, though it is almost universal in parents, hath always appeared to me to be the most unaccountable of all the absurdities which ever entered into the brain of that strange podigious creature man." 3

When Honour informed Jones that Sophia had been carried away by her father who was "swearing she should marry Mr. Blifel," Jones's reply struck the very heart of the issue. The last sentence must have put parents in mind and convinced them that, henceforth, a determined attitude toward this important matter, such as it had been, would no longer be tolerated. "'Indeed, Mrs. Honour, answered Jones, 'you frighten me out of my wits. I imagined some

1. "Tom Jones," Bk. VI, Ch. it.

3. "Ibld.," Bk. VII, Ch. Ix. 
most dreadful sudden accident had happened to Sophia, something, comparable to which, even the seeing her married to Blifel would be a trifling incident; but while there is life there are hopes, my dear Honour. Women in this land of liberty cannot be married by actual brute force." "1 


\section{CHAPTER VII \\ CONCLUSIONS}

The preceding chapters are intended to show that the rise of the modern novel was not the result of chance; and that the subsequent development of the new art was not haphazard and without design. The broad, fundamental principles that constituted the theory of the novel after 1740 give definite and fairly conclusive evidence that there was unity in the aims of the novelists throughout this period. The main conclusions may well be summed up in this final chapter.

The new type of fiction began with Richardson's "Pamela" in 1740. The matter-of-fact realism of this first novel of character continued in varying degrees throughout the century. "The stern endeavor to keep the imaginative product in harmony with the actual" was at no time seriously weakened; not even by those Gothic writers who declared that it was their intention to do so. Richardson, Fielding, Johnson, and Sterne assumed a directive and dictatorial attitude toward the realistic-an attitude quite in keeping with the mood of the eighteenth century. With the accepted theories of human nature, authors were not permitted to take unlimited freedom. The leading characters, the most characteristic conversations, the situations, and the incidents struck their roots deep in human nature. These internal features of the novel evolved from a close study of real life-of contemporary English life. "The works of fiction, with which the present generation seems more particularly delighted," Johnson wrote, "are such as exhibit life in the true state, diversified only by accidents that daily happen in the world, and influenced by passion and qualities which are really to be found in conversation with mankind." It was desired and expected of the author that he would keep the plot and the machinery of the piece within the bounds of probability and within the range of credibility. The author who disregarded these fundamen- 
tal matters, did so at the peril of his literary reputation. "Truth in art" was the watch-word of eighteenth-century realism.

Nearly every leading author of this period announced in his preface to each novel a strictly moral, or, at least, semimoral purpose. This bold profession was generally made good in the development of the narrative. Richardson was eager to steal in and investigate the great doctrines of Christianity. Authors seem to have taken their cue from him in this; at least they do him honor by following in his footsteps. Fielding, by far the ablest artist of them allone who probably cared very little for purely didactic subjects, appears to have been much more concerned about a moral purpose in "Amelia," his last novel, than he was in his earlier productions. The leading characters were generally held up as "models of prudence, and patterns of piety." "Lady Darnford. . . kissed me with a kind of rapture," Pamela wrote, "and called me a sweet example for all my sex."

Defection of the Gothic authors from the established principles of Richardson, Fielding, and Johnson was more apparent than it was real. The departure was limited mainly to the introduction of machinery from the Middle Age. But this material was shorn of the spirit of that time. The professed desire was merely to unite the ancient and the modern-the real and the commonplace with the supernatural and the fanciful. The result of this blending was a new type of novel, but one that was in some important particulars not unlike "Clarissa Harlowe," "The Vicar of Wakefield," and "Tristram Shandy." There is really very little difference between the sentimentalism of Richardson, Goldsmith, Sterne, and Henry Mackenzie, and that of Walpole, Miss Reeve, and Mrs. Radcliffe. Very little distinction can be made between the emotions of a man who weeps from the sheer memory of a sad tale, or from fear of the dark and things uncanny, or from a picturesque scene of nature. They constitute differences that are without distinction. In each instance it is "sensibility," defined by Mrs. Radcliffe as a "dangerous quality which is continually extracting the excesses of misery or delight from every sur- 
rounding object." Godwin of course was radical. But the radicalism of his political philosophy led him to differ from the realists in degree rather than in theme or purpose. For social, moral and religious reform of the earlier realists, he deliberately and boldly substituted political reform. They believed that those external influences that enter into the making of character and opinion, are religious and moral; Godwin held that those influences are political, and for those principles he contended in his novel with all the fire and zeal of his soul. This deep-seated, passionate,flaming desire of Godwin's for something better than had hitherto been known, lights up the otherwise gloomy pages of his novel; and it links him in spirit with the romantic movement much more closely than are Walpole and others linked through the Gothic novel. " 'Caleb Williams' is incomparably the best of his novels, and the one great work of fiction in our language which owes its existence to the fruitful union of the revolutionary and romantic movements."

The realistic vein of the eighteenth-century novel doubtless made the middle-class of people more conscious of themselves as a class and as individuals-as men among men. The rather faint romantic vein aided them in attaining a higher conception of personality. 


\section{BIBLIOGRAPHY}

(The following list contains the most important works referied to in the text anil footuotes).

BARBAULD, ANNA LAETTTA. "Correspondence of Samuel Richardson." 6 Vols. London, 1804.

BEERS, HENRY A. "A History of English Romnnticism in the Elghtcenth Century." Henry Holt and Company, New York, 1890 .

BOSWELL, JAMES. "Life of Johnson," Birkbeck Hill Edition, 6 Vols. Harper und Brothers, New York, 1891.

BURNEY, FANNY. "Evelina." (Introduction by Austin Dobson). Macmillan and Company, New York and London, 1904.

BURTON, RICHARD. "Masters of the English Novel." Henry Holt and Company, New York, 1909.

"Cambridge History of English Literature." Cambridge: at the University Press. "Critical Review." London.

CROSS, WILBER L. "The Development of the English Novel." The Macinillan Compuny, New York, 1900 . Haven, 1911 .

CUNNINGHAiI, PETER. "The Letters of Horace Walpole,": 9 Vols. Henry C. Bohn, London, 1861.

DOBSON, AUSTIN. "Sumuel Richardson." (Inglish Men of Letters Series). The Macmillan Company, New York, 1902.

ERIERSON, RALPH WALDO. "Society and Solitude," 'Books.' Houghton MAfflin and Company, Boston, 1883.

' FIELDING, HIENRY.

"Amelia," 2 Vols.

"Joseph Andrews"

"Jonathan Wild"

"Journey from This World to the Next, $A$ "

"Tom Jones," 3 Vols.

The Complete Works of Henry Fielding, Esq., with an Essay on the Life, Genlus, and the Achicvements of the Author, by William Ernest Henley, LL.D. Croscup and Sterling Company, New York, 1902.

GoDWIN, WillicM. "Calcb Williams," 3 Vols. London, 1831.

GOLDSMITH, OLIVER. "The Vicar of Wakcheld." Cassel and Company, New Yor'k

HAMMLTON, CLAYTON. "Materinls and Methods of Fiction." (Introduction by Brander Matthews). The Baker and Taylor Company, New York, 1908.

HAZLITT, WILILAN. "English Comic Writers" "Spirit of the Age, The"

HUNT, LEIGH. "Men, Women, and Books." Smith, Elder, and Company, London, 1801.

JOHNSON, SAMUEL

"Ramblex," The London, 1881 .

LANIER, SIDNEY. "The English Novel." Charles Seribner's Sons, New York, 1897.

LEWIS, MatThEW GREgory. "The Monls." (Edited bJ E. A. Baker). E. P. Dutton and Company, New York, 1907.

MACKENZIE, HENRY. "The Man of Feeling." London, 1820.

MONTAGU, LADY MARY WORTLEY. Works, 5 Vols. London, 1817.

MTPTCATP, TOHN CALVIN. "Henry Fielding, Critic" The Sewanee Review, XIX, 1911 . 
PERRY, BLISS. “A Study of Prose Fiction." Houghton Mimin and Company, New York, 1902 .

PHELPS, WILLIAM LLYON.

"The Advance of the English Novel." Dodd, Meade, and Company, New "The 1916. pany, New York, 1893.

RADCLIFFE, MRS. ANNE. "The Mysterles of Udolpho." Derby and Jackson, New York, 1857.

RALEIGH, WALTER. "The English Novel." Charles Scribner's Sons, New York, 1894.

REEVE, CLARA. "The Old English Baron." J. C. Nemmo and Lain, London, 1883.

RICHARDSON, SAMUEL

"Clarissa Harlowe," 8 Vols.

"Pamela, or Virtue Rewarded," 4 Vols.

"Samela, or Virtue Retwarded,"

(Introduction by William Liyon Phelps). Croscup and Sterling Company, New York, 1902.

SAINTSBURY, GEORGE

"A History of Criticism and Literary Taste," 3 Vols. Dodd Meade, and Company, New York, 1900 . "A Short History of English Literature." Macmillan Company, London, 1898.

SCARBOROUGH, DOROTHY. "The Supernatural in Modern English Prose Fiction." G. P. Putnam's Sons, New York, 1917.

SMOLLETT, TOBIAS.

"Adventures of Ferdinand Count Fathom, The"

"Adventures of Roderick Random, The"

"Expedition of Humphrey Clinker, "The"

George Routledge and Sons, London, 1900

"Spectator," The

STEELE, SIR RICHARD. "The Conscious Lovers." (Mermaid Series). The Best Plays of the Old Dramatists. Edited with Introduction and Notes by G. A. Aitken. Charles Scribner's Sons, New York, 1894.

STEPHEN, SIR LESLIE.

"English Literature and Soclety in the Eighteenth Century." Ford Lectures, 1903. G. P. Putnam's Sons, New York and London, 1907 "Tures, 1903. G. P. Punam's Sons, P. Putnam's Sons, New York; Smith, Elder, and Company, London, 1902 .

STERNE, IAURENCE.

"Sentimental Journey, A"

"Tristram Shandy"

The works of Laurence Sterne, 4 Vols. Edited by James P. Browne, M.D., London, 1873.

STODDARD, FRANCIS HOVEY. "The Evolution of the English Novel." The Macmillan Company, New York, 1900.

THOMPSON, CLARA to "Samuel Richardson," A Blographical and Critical Study' (Contains a useful Bibliography.) M. F. Mansfleld and Company, New York; Horace Marshall and Sons, London, 1900.

WALPOLE, HORACE. "The Castle of Otranto." J. C. Nemmo and Baine, London, 1883 .

WHITEFORD, ROBERT NAYLOR. "Motives in English Fiction." G. P. Putnam's Sons, New York and London, 1018. 


\section{INDEX}

Addison, Joseph, 7, 12, 13, 18, 21

"Amelia," 40; purpose of, 52-53; 54, 133, 135

Barbauld, Anna Laetitia, 26, 42, 44, 45 Becrs, Professor Henry A., 89; defnes romanticism, 90; 93, 90,108, 110, 111, 135

Blackwood's, 51

Browning, Robert, 22

Burney, Funny, 25, 67, 135

Burton, Professor Richard, deflnes the modern novel, 125,135

"Caleb Williams," 30 ; moral of, 61-65; 92, 106, 109, 110, 134, 135

"Costle of Otranto, The," 31, 32-33; 34, $36,41,64.67,86,87,88,101,102,103$, $104,106,107,108,110,112,136$

"Cato," 9

Character-sketch, The, ready to the novelist's hand, 11-13; 21

"Clarissa Harlowe," 9, 21, 22, 30, 44; purpose of, $45-48 ; 51,56,66,67,71$, $72,73,74 ;$ Lanier's opinion of, 73 ; 75;
$87,98,113,116,128-120,133,136$

"Conscious Lovers, The," 9

Corvper, William, 92

Critical Review, 44, 135

Cross, Professor WV. L., 9, 10, 26, 38, 39, $40,41,49,50,50,61,63,66,72,80,98$, $113,115,127-128,135$

Defoe, Danicl, 7, 113

Dobson, Austin, 68, 123-124, 135

Drama, The, decadent, gives way to the novel, 8 ; resembles the novel, 9 ; 1 A

Dryden, John, 7

Emerson, Ralph Waldo, on the imagtnation, 112 (note)

Essay, The, contributions to the novel, $11-20$

"Evelina," 25, 67, 135

"Ferdinand Count Fathom," 41, 136

Fielding, Henry, 8, 9; ridicules taste for moralization, 9-10; 12; hegins "Toseph Andrews" as a parody of "Pamela," 24-25; frst to grasp prin$29 ; 30,36,37,38,39,40,41,47,49,51$, as a reformer, $55 ; 64,66,67,68$; ridicules follies and vices, 77 ; expounds meaning of the "ridiculous," $77-79$; not a religious enthusiast, $80-81 ; 84$ $93,98,112,113,114,115,121,124$; on the lack of natural nffection, 127 (note); 128, 130, 132, 133, 135

Godwin, Whlliam, exponent of social and political justice, 64; 65, 68, 69, $72,82,113,114,115,133,135$

Goldsmith, Oliver, 7, 8, 63, 64, 67, 68, $69,72,92,113,114,115,133,135$

Gray, Thomas, 92, 97

Hazlitt, Wllliam, 29, 68; three different kinds of the laughable, $76 ; 109$
Hedge, Frederick Eenry, defines the
romnntic, $89 ; 98$ Hugo, Victor, deflnes the romnntic, 89 "Humphrey Clinker," 93-95, 136

Hunt, Leigh, 37

Jefrerson, Thomas, 114

Johnson, Samuel, $7,18,36,57,64$; on the length of Richardson's novels,
$70 ; 97,112,132,133,135$

"Jonnthan Wild," 53, 135

"Joseph Andrews," १-10, 24, 25, 26, 38, $51,52,53-54,80,98,118,119,120,122$, $12,3,135$

Lonier, Sidney, opinion of "Clarissa Letter, The, contributions to the novel, 20-23; 11

Lewis, Mnthew Gregory, 68, 100,102, 103, $105,107,108,110,135$

Macaulay, Thomas Babington, 87

Mackenzie, Henry, 133 (note), 135

"Man of Feeling, The," most sentimental novel, 74 (note); 135

Metcalf, Professor John Calvin, 37, 80, 135

"Monk, The," 101, 102, i04, 106, 108, 135

Mantagu, Lady Mary Wortley, 7-8, 20, 10, 124, 125, 135

"Mysteries of Udolpho, The," 30, 30, 73 $75,76,90,93,94,95,96,97,98,102$, $104,110,135$

Novel, The, uncertainty as to exnct beginning of, 7 ; birth of, 8; supersedes the drama, 8 ; predestined success of, 9; more serviceable than the drama, 11 ; like the essay, 11 ; loosely construeted plots of earlier novels, 13; epistolary style of writing, 20 22; general constructive theories comprehended under four principles, 27; a criticism of life, 43; the menns of reaching the inner life, is; deflnition of the modern novel, 125

“old English Baron, The," 30, 33-35, 64, 101, 136

"Pamela," 13 ; origin of the story, 13 18; $22,24,44 ; 26,29,42$; purpose of $45,49,51,68,73,74,116-117,119,120$ bridged gulf between rich and poor 123-124; 125-127, 132, 135

Perry, Professor Bliss, truth the keynote of the novelist's art, $52 ; 66$; theory of realism, 67; 135

Phelps, Professor William Llyon, 8, 55, 75, 90 (note), 135

Poe, Edgar Allan, 108

Pope, Alexander, 31, 30, 37, 92

Radcliffe, Mrs Anne, 35, 36, 68; defnes the new emotionalism, 73; 75, 93, 94, $97,99,193,135$

Raleigh, Wniter, 9, 12, 25, 36, 43, 55 $68,72,100,112,135$

Ramblex, The, 57-61; 135

"Rasselag," 18, 19; purpose of, 57 ; 138 
Reeve, Clara, 33, 35, 61, 68, 101, 110, 133,136

Hichardson, Samuel, 7, 8, 9, 12, 13; 18 20,21 ; theory of letter-writing, 21 22 ; writes to Hill, $24 ; 26,30,30,41$ 42, 43, 45, 17, 48, 49; criticises "Tom Jones," 49-50; his acquaintanec chiefiy among the ladfes, 51; 52,55, 67 ; founder of a school of novelists, 68 60 $70,71,72,75,84,87^{\circ}, 08,08,112$ 11. $7,7,72,75,84,85,93,38,112$ the eplstoliry method, 116; 121, 125 $126,128,132,133,136$

"Roderick Random," 13, 41, 60, 81, 84, 130

Saintsbury, Professor George, 01, 82, 83,136

Scott, Sir Wulter, 27, 63

Sewanee Review, 130

"Sir Charles Grandison," 20, 44, 46, 71, 75,130

Smollett, Tobias, 13, 36, 41; a naturalist, $55 ; 56,60,67,68$; use of satire $81 ; 94,98,103,124,138$

Soliloquy, The, contributions to the novel, 22-23

Spectator, The, 13, 26, 136

Steele, Sir Richard, 9, 12, 13, 21

Stephen, Sir Lesle, 37; menning of sentimentalism, 72 (note) and $76 ; 87$, 95,112 (note), 113, 130 Sterne, Laurence, 8, 31, 36, 40, 41, 57;
characterizes Shandolsm, 57 ; innu- ance of, (11-(ji); (6.1, (3i), 67, 68, 69, 72 75; ridieu!es afrectations, 81 ; lumus of, 82; trics to smnsli literiry conventions, 8:3-84; on the "reason," 112 (note): 114, 115 , 1 (note) : 114, 115, 132, 130

Stoddard, professor Francis Hovey, 23 $36,42,87$; defines the romantic, 89 ; $11.1,115,116,136$

Tennyson, Alfred, 88

Thompson, Clara L., 20, 23, 48, 130

"Tom Jones," 11, 30, 37, 38, 39, 40, 41; criticised by Hill's dauglaters, 19; 52 $53,54,56,67,80,81,81,87,98,110$ (note), 127 (note), 130-131, 135

"Tristram Shandy," 31-32, 40, 57, 6.7, $66,69,81,82 ;$ purpose of, 84 ; 112 (note), 133, 136

"Vathek," 36

"Vicar of Wakefield, The," 63, 70, 75, 133,135

"Vision of Mirza, The," closely resembles "Rassclas," 18-20

"Voyage to Lisbon, The," 54, 135

Walpole, Hornce, 8, 20; attempts to blend the wonderful of the old tories with the natural of modern lovels, 25; $31,32,33,34,35$, 36, 41, 44, $35,67,68$; writes concerning his innovation, $86 ; 87,88,93,99,101,102$, 103 ; on the function of terror, 106; $108,110,112,133,134,136$

Whiteford, Professor Robert Naylor, 19,136 